\title{
Current vitamin D status in European and Middle East countries and strategies to prevent vitamin D deficiency: a position statement of the European Calcified Tissue Society
}

\author{
Paul Lips ${ }^{1}$, Kevin D Cashman², Christel Lamberg-Allardt ${ }^{3}$, Heike Annette Bischoff-Ferrari ${ }^{4}$, Barbara \\ Obermayer-Pietsch ${ }^{5}$, Maria Luisa Bianchi ${ }^{6}$, Jan Stepan7, Ghada El-Hajj Fuleihan ${ }^{8}$ and Roger Bouillon ${ }^{9}$ \\ on behalf of the Working Group on Vitamin D of the European Calcified Tissue Society
}

\begin{abstract}
${ }^{1}$ Endocrine Section, Department of Internal Medicine, Amsterdam University Medical Center, VUMC, Amsterdam, The Netherlands, ${ }^{2}$ Cork Centre for Vitamin D and Nutrition Research, School of Food and Nutritional Sciences, Department of Medicine, University College Cork, Cork, Ireland, ${ }^{3}$ Calcium Research Unit, Department of Food and Nutritional Sciences, University of Helsinki, Helsinki, Finland, ${ }^{4}$ Department of Geriatrics and Aging Research, University Hospital and University of Zurich, Zurich, Switzerland, ${ }^{5}$ Division of Endocrinology and Diabetology, Department of Internal Medicine, Medical University Graz, Graz, Austria, ${ }^{6}$ Bone Metabolism Unit, Istituto Auxologico Italiano IRCCS, Milano, Italy, ${ }^{7}$ Institute of Rheumatology, Faculty of Medicine, Charles University, Prague, Czech Republic, ${ }^{8}$ Calcium Metabolism and Osteoporosis Program, WHO Collaborating Center for Metabolic Bone Disorders, American University of Beirut Medical Center, Beirut, Lebanon, and ${ }^{9} \mathrm{Clinic}$ and Laboratory of Endocrinology, Gasthuisberg, KU Leuven, Leuven, Belgium

(Dedicated to the memory of Prof. Steven Boonen and Prof. Silvano Adami)

Correspondence should be addressed to P Lips Email p.lips@vumc.nl
\end{abstract}

\begin{abstract}
Vitamin D deficiency (serum 25-hydroxyvitamin D $(25(\mathrm{OH}) \mathrm{D})<50 \mathrm{nmol} / \mathrm{L}$ or $20 \mathrm{ng} / \mathrm{mL}$ ) is common in Europe and the Middle East. It occurs in $<20 \%$ of the population in Northern Europe, in $30-60 \%$ in Western, Southern and Eastern Europe and up to $80 \%$ in Middle East countries. Severe deficiency (serum $25(\mathrm{OH}) \mathrm{D}<30 \mathrm{nmol} / \mathrm{L}$ or $12 \mathrm{ng} / \mathrm{mL}$ ) is found in $>10 \%$ of Europeans. The European Calcified Tissue Society (ECTS) advises that the measurement of serum 25(OH) D be standardized, for example, by the Vitamin D Standardization Program. Risk groups include young children, adolescents, pregnant women, older people (especially the institutionalized) and non-Western immigrants. Consequences of vitamin D deficiency include mineralization defects and lower bone mineral density causing fractures. Extra-skeletal consequences may be muscle weakness, falls and acute respiratory infection, and are the subject of large ongoing clinical trials. The ECTS advises to improve vitamin D status by food fortification and the use of vitamin D supplements in risk groups. Fortification of foods by adding vitamin D to dairy products, bread and cereals can improve the vitamin $D$ status of the whole population, but quality assurance monitoring is needed to prevent intoxication. Specific risk groups such as infants and children up to 3 years, pregnant women, older persons and nonWestern immigrants should routinely receive vitamin D supplements. Future research should include genetic studies to better define individual vulnerability for vitamin D deficiency, and Mendelian randomization studies to address the effect of vitamin D deficiency on long-term non-skeletal outcomes such as cancer.
\end{abstract}




\section{Introduction}

The clinical practice committee of the European Calcified Tissue Society (ECTS) met during the European Calcified Tissue Symposium at Stockholm in May 2012. The different guidelines of the Institute of Medicine (IOM) and the Endocrine Society $(1,2)$ were discussed, including their different scopes, the many uncertainties surrounding the required circulating 25-hydroxyvitamin D (25(OH)D) concentrations, supplementation doses and extra-skeletal effects of vitamin D (3). While the IOM's recommendations were directed at population health, the Endocrine Society guidelines aimed at a clinical care perspective. The members agreed that a European statement outlined in a position paper would be appropriate. A working group was established to prepare a position statement regarding various aspects of vitamin D deficiency and prevention for Europe and the Middle East. Such a document should be appropriate following the recent reports of the IOM, the guidelines of the Endocrine Society, the statement of the Standing Committee of European Doctors and reports from the Scientific Advisory Committee on Nutrition (SACN) (https://www.gov.uk /government/publications/sacn-vitamin-d-and-health-report) in the UK, the European Food Safety Authority (EFSA) (https://www.efsa.europa.eu/en/efsajournal/pub/4547) for Europe as well as the ongoing discussions in the American, European and international journals.

The present position paper discusses assessment of vitamin $\mathrm{D}$ status and standardization of measurement of $25(\mathrm{OH}) \mathrm{D}$ concentration. It includes an overview of the vitamin $\mathrm{D}$ status and vitamin $\mathrm{D}$ intake in different European and Middle East countries, the prevalence of vitamin D deficiency according to different thresholds, the required circulating 25(OH)D concentrations and required vitamin D intake (from food and/or supplements) to prevent vitamin $\mathrm{D}$ deficiency and possible impact on skeletal and non-skeletal outcomes. The perspective of the ECTS Working Group was the whole population, including risk groups such as children, older persons and immigrants. Data on food fortification policy and the use of supplements in risk groups are included. The ECTS Working Group discussed strategic options and proposes possible implementation strategies for adults and elderly subjects in Europe and the Middle East. Finally recommendations and a research agenda are presented.

\section{Assessment of serum 25-hydroxyvitamin D}

There is a general consensus, also adopted by the ECTS, that the serum/plasma 25(OH)D concentration is the best indicator of vitamin D nutritional status, as it reflects the contributions from diet and dermal production in response to ultraviolet B (UVB) sunlight exposure (4). It is not surprising therefore that serum/plasma $25(\mathrm{OH})$ $\mathrm{D}$ was used as an indicator of vitamin $\mathrm{D}$ status recently by several authorities in North America and Europe who were commissioned to establish dietary reference intake values for vitamin $\mathrm{D}$.

The circulating concentration of total $25(\mathrm{OH}) \mathrm{D}$ (i.e. comprising the sum of $25(\mathrm{OH}) \mathrm{D}_{2}$ and $\left.25(\mathrm{OH}) \mathrm{D}_{3}\right)$ is used diagnostically and clinically as well as in the derivation of dietary reference values for vitamin $\mathrm{D}$. While vitamin $\mathrm{D}_{3}$ comes from skin synthesis or animal sources, vitamin $\mathrm{D}_{2}$ is derived from supplements or irradiated foods. As the biological activity of the C3 epimer of serum $25(\mathrm{OH}) \mathrm{D}$ is low and its concentration in adults represents only a small fraction of the total $25(\mathrm{OH}) \mathrm{D}$ concentration, its separate measurement is not a priority, certainly not in adults. Ideally, measurement of serum $25(\mathrm{OH}) \mathrm{D}$ should have a minimal interference from $24,25(\mathrm{OH})_{2} \mathrm{D}$ - the vitamin $\mathrm{D}$ metabolite with the highest concentration apart from $25(\mathrm{OH}) \mathrm{D}_{3}(5,6,7)$. Separate measurement of $24,25(\mathrm{OH})_{2} \mathrm{D}$ may be important in case of suspected genetic CYP24A1 deficiency $(8,9)$. Measurement of serum $1 \alpha, 25(\mathrm{OH})_{2} \mathrm{D}$ can be important for establishing the etiology of hyperor hypocalcemia and some metabolic bone diseases but not for the general assessment of the vitamin $\mathrm{D}$ status in a population or individual. Serum $1 \alpha, 25(\mathrm{OH})_{2} \mathrm{D}$ may be high in patients with inflammatory and granulomatous diseases and lymphoproliferative disorders $(10,11)$.

The impact of pre-analytical factors (e.g. serum versus plasma, fasting versus non-fasting state, or time of day) on circulating $25(\mathrm{OH}) \mathrm{D}$ is not fully defined. Several assay types are currently in use for measurement of circulating $25(\mathrm{OH}) \mathrm{D}$, each with strengths and weaknesses (12). The two most common types of assays are (1) antibodybased methods, which use a kit or an automated clinical chemistry platform; and (2) liquid chromatography (LC)based methods with either UV or mass spectrometric (MS) detection. While they will both provide a measure of total serum $25(\mathrm{OH}) \mathrm{D}$, mass spectrometry can allow for the separate estimation of $25(\mathrm{OH}) \mathrm{D}_{2}$ and $25(\mathrm{OH}) \mathrm{D}_{3}$ (and in some cases the $\mathrm{C}-3$ epimers and $24,25(\mathrm{OH})_{2} \mathrm{D}$ ) from serum samples. The antibody-based methods lack the features that allow them to distinguish between $25(\mathrm{OH}) \mathrm{D}_{2}$ and $25(\mathrm{OH}) \mathrm{D}_{3}(4,7,10,13)$. Various commercial assays differ because of the nature of the antibody used, some claiming an advantage that they do not discriminate between $25(\mathrm{OH}) \mathrm{D}_{2}$ and $25(\mathrm{OH}) \mathrm{D}_{3}(13)$, whereas others in fact do underestimate the $25(\mathrm{OH}) \mathrm{D}_{2}$ component and therefore 
provide correction factors to compensate for high $25(\mathrm{OH})$ $\mathrm{D}_{2}$ content $(2,14)$. It is important to note that the majority of the data collected over the past 20-30 years have been analyzed using antibody-based assays. LC-based assays using a tandem mass spectrometer (LC-MS/MS) allow the analyst to discriminate between $25(\mathrm{OH}) \mathrm{D}_{2}$ and $25(\mathrm{OH}) \mathrm{D}_{3}$ and other compounds by their unique molecular masses and mass fragments (12). The potential advantages of LC-based assays include high specificity, high sensitivity and better reproducibility $(<10 \%)$. The consensus among analysts is that LC-MS/MS assays will become the 'gold standard' for assay performance in the future (15). However, LC-MS/MS will not be available everywhere, and antibody-based assays are still being improved and cross-calibrated against LC-MS/MS, so that smaller labs will be able to perform adequate measurements provided they participate in a quality control program. In the circulation, $25(\mathrm{OH}) \mathrm{D}$ is bound to serum proteins, and unbound or free $25(\mathrm{OH}) \mathrm{D}$ constitutes $<1 \%$ of the total concentration. As only free $25(\mathrm{OH}) \mathrm{D}$ can enter the cell for further intra/paracrine production of the active metabolite $1,25(\mathrm{OH})_{2} \mathrm{D}$, it is plausible that free $25(\mathrm{OH}) \mathrm{D}$ is more important for local actions than total $25(\mathrm{OH}) \mathrm{D}$. The free $25(\mathrm{OH}) \mathrm{D}$ concentration can either be calculated (based on vitamin D-binding protein (DBP), albumin and total 25(OH)D concentrations and the affinity between both components) or can be directly measured. Whether free $25(\mathrm{OH}) \mathrm{D}$ is a better predictor for clinical outcomes than total $25(\mathrm{OH}) \mathrm{D}$ is presently unclear $(16)$.

\section{Standardization of the measurement of serum 25(OH)D}

Standard referencematerials, inter-laboratory collaboration and quality assurance schemes are important aspects of overcoming the challenges that the assay methodologies present. An external quality assurance scheme, the Vitamin D External Quality Assurance Scheme (or DEQAS) (www.deqas.org, Charing Cross Hospital in London, UK), exists since the early 1990s and it has grown steadily, such that it now serves as a quarterly monitor of performance of analysts and 25(OH)D analytical methods for more than 1000 laboratories worldwide $(5,17,18,19,20)$. The introduction of the National Institute of Standards and Technology (NIST) reference standards, calibrated using a reference LC-MS/MS procedure, offers hope that the variability of all methods will be diminished in the future. Recent data suggest that an improvement is already occurring (18) but there is still a long way to go for general implementation of well-validated and accurate measurements of vitamin D metabolites $(20,21,22)$.

For reasons of pre-analytical as well as analytical factors, as outlined above, inter-laboratory variation in serum $25(\mathrm{OH}) \mathrm{D}$ may be high $(17,18,19,23,24,25)$. The international standardization of serum $25(\mathrm{OH})$ $\mathrm{D}$ measurement is also promoted by the Vitamin D Standardization Program (VDSP) - a collaborative initiative between the Office of Dietary Supplements of the National Institutes of Health and the Centers for Disease Control and Prevention (CDC), NIST and a number of the national health surveys around the world $(21,26)$. The international quality assurance/collaboration schemes, such as DEQAS and VDSP, as well as existing and next generation standard reference materials for $25(\mathrm{OH}) \mathrm{D}$, can further limit inter-laboratory differences. The impact of standardization to NIST standards has been amply demonstrated by recalibration of the (US) NHANES data (27), whereby the J-shaped increased mortality in subjects with high serum 25(OH)D concentration disappeared simply because very few subjects had 'corrected' $25(\mathrm{OH})$ D levels above $100 \mathrm{nmol} / \mathrm{L}$. Similarly, a recalibration of European studies in the framework of the EU Framework 7-funded ODIN project (food-based solutions for optimal vitamin D nutrition and health through the life cycle; https://arquivo.pt/wayback/20160421110252/http:// www.odin-vitd.eu/) markedly changed the number of vitamin D deficient subjects (28).

\section{Definitions}

An international consensus on the definition of vitamin D deficiency and sufficiency is lacking. The IOM has defined a serum $25(\mathrm{OH}) \mathrm{D}$ concentration of $30 \mathrm{nmol} / \mathrm{L}$ (divide by the conversion factor 2.496 to obtain $12 \mathrm{ng} / \mathrm{mL}$ ) as the threshold below which clinical vitamin D deficiency may occur $(2,14,19)$. It has defined a $25(\mathrm{OH}) \mathrm{D}$ concentration of $50 \mathrm{nmol} / \mathrm{L}(20 \mathrm{ng} / \mathrm{mL})$ as the threshold of sufficiency, that is sufficient for $97.5 \%$ of the population in terms of bone health, a definition also recently adopted by the EFSA (29). The serum concentration of $40 \mathrm{nmol} / \mathrm{L}$ fits with the estimated average requirement (EAR), that is sufficient for $50 \%$ of the population. Serum $25(\mathrm{OH}) \mathrm{D}$ levels between 30 and $50 \mathrm{nmol} / \mathrm{L}$ (12 and $20 \mathrm{ng} / \mathrm{mL}$ ), referred to by the IOM as 'inadequacy', represent an uncertain range and can be sufficient or not for a certain individual (Table 1).

The Endocrine Society has defined serum 25(OH)D of $50 \mathrm{nmol} / \mathrm{L}(20 \mathrm{ng} / \mathrm{mL})$ as the threshold for deficiency and $75 \mathrm{nmol} / \mathrm{L}(30 \mathrm{ng} / \mathrm{mL})$ as the threshold for sufficiency, that is sufficient for $97.5 \%$ of the population (1). The 2016 UK 
Table 1 Definitions of vitamin D deficiency and sufficiency according to different advisory bodies.

\begin{tabular}{|c|c|c|c|c|c|}
\hline Serum 25(OH)D concentration $(\mathrm{nmol} / \mathrm{L})$ & Institute of Medicine (2) & Endocrine Society (1) & EFSA (29) & SACN (27) & ECTS (this paper) \\
\hline$<25 / 30$ & Deficient & Deficient & Deficient & Deficient & Severely deficient \\
\hline $25-50$ & Uncertain* & Deficient & Deficient & & Deficient \\
\hline $50-75$ & Sufficient & Insufficient & Sufficient & & Sufficient \\
\hline$>75$ & & Sufficient & & & \\
\hline
\end{tabular}

*According to the IOM serum 25(OH)D 30-50 nmol/L can be adequate or inadequate.

SACN guidelines defined serum $25(\mathrm{OH}) \mathrm{D}$ concentrations below $25 \mathrm{nmol} / \mathrm{L}$ as being deficient for all age groups but concluded that there was insufficient evidence to define a higher 25(OH)D being optimal for bone or global health (30).

The ECTS Working Group defines vitamin D deficiency as a serum $25(\mathrm{OH}) \mathrm{D}$ concentration below $50 \mathrm{nmol} / \mathrm{L}$. A serum $25(\mathrm{OH}) \mathrm{D}$ level below $30 \mathrm{nmol} / \mathrm{L}$ is considered severe vitamin D deficiency. A serum 25(OH)D concentration of $50 \mathrm{nmol} / \mathrm{L}$ and above is considered sufficient.

A problem with these definitions is that they heavily rely on the accuracy of serum $25(\mathrm{OH}) \mathrm{D}$ measurement. The latter depends on standardization and the discussions on this subject have not been finalized (28).

In this review, results for serum $25(\mathrm{OH}) \mathrm{D}$ are reported in $\mathrm{nmol} / \mathrm{L}(1 \mathrm{nmol} / \mathrm{L}=0.4 \mathrm{ng} / \mathrm{mL})$. Vitamin $\mathrm{D}$ intake can be presented in IU/day or in $\mu \mathrm{g} /$ day $(1 \mu \mathrm{g}=40 \mathrm{IU})$. While clinicians often use IU/day, nutritionists usually prefer $\mu \mathrm{g} /$ day. We have chosen the use of $\mu \mathrm{g} /$ day, with frequent reference to the conversion factor for ease of the reader.

\section{Vitamin D status and prevalence of vitamin D deficiency in Europe}

Vitamin D status has been studied in many European countries in various age groups. Since different studies use different laboratories and different assays, the data should be compared with caution because, as mentioned above, the inter-laboratory variation may be high $(19,23)$. Another point is the study population which may be either a population sample (31) or a convenience sample (32). Data from various studies in different European countries are summarized in Table 2. Recent reviews on vitamin D status in Europe or worldwide were published by Spiro and Buttriss, Wahl et al. and Hilger et al. (33, 34, 35).

The ODIN project (28) as well as a small project funded by the Nordic Council of Ministers (36) have recently allowed for the generation of standardized serum $25(\mathrm{OH})$ $\mathrm{D}$ data which facilitates estimating and comparing the prevalence of vitamin D deficiency in various European countries. These projects utilized available biobanks from national nutrition and health surveys and cohorts in Europe and used a centralized laboratory LC-MS/MS analytical platform for $25(\mathrm{OH}) \mathrm{D}$, which is traceable to the two higher order reference measurement procedures (NIST, VDSP) and certified by the Centres for Disease Control and Prevention (CDC). The data from these projects together with data from other studies in different countries in Europe and the Middle East is summarized in Table 2. We have selected studies from the last 10 years, and, where available, prioritized populationbased studies having standardized serum 25(OH)D values according to the VDSP program.

\section{Northern Europe}

The prevalence of serum $25(\mathrm{OH}) \mathrm{D}<30 \mathrm{nmol} / \mathrm{L}$ ranged from 0.4 to $8.4 \%$, and $<50 \mathrm{nmol} / \mathrm{L}$ from 6.6 to $33.6 \%$ in adults, according to standardized data from the ODIN study, and some Nordic studies (28, 36, 37, 38, 39). However, vitamin D status was poor in teenagers in Norway and Denmark with serum $25(\mathrm{OH}) \mathrm{D}<30 \mathrm{nmol} / \mathrm{L}$ at $39 \%$ and $51 \%$ respectively $(40,41)$. Vitamin D status was also poor in immigrants $(42,43)$, and in older persons, especially residents of nursing homes $(44,45)$. The generally adequate vitamin D status in the Nordic countries is due to the use of cod liver oil and supplements (46) and vitamin $\mathrm{D}$ fortification, leading to a great improvement in Finland during the last decade (47).

\section{Western Europe}

The prevalence of serum $25(\mathrm{OH}) \mathrm{D}<30 \mathrm{nmol} / \mathrm{L}$ ranged from 4.6 to $30.7 \%$ and $<50 \mathrm{nmol} / \mathrm{L}$ from 27.2 to $61.4 \%$ according to standardized data from ODIN (28). Vitamin D status generally was worse in the UK $(30.7 \%<30 \mathrm{nmol} / \mathrm{L}$ and $61.4 \%<50 \mathrm{nmol} / \mathrm{L})$ than in other countries $(25,28$, $48,49,50,51,52,53,54,55,56,57,58,59,60,61,62$ ), and recently a rise in the incidence of rickets was observed (63). A poor vitamin D status was observed in black and Asian people in the UK, in teenagers and adolescents in the UK $(25,48)$, in (pregnant) non-Western immigrants $(64,65)$ and in general in older persons $(66)$. 


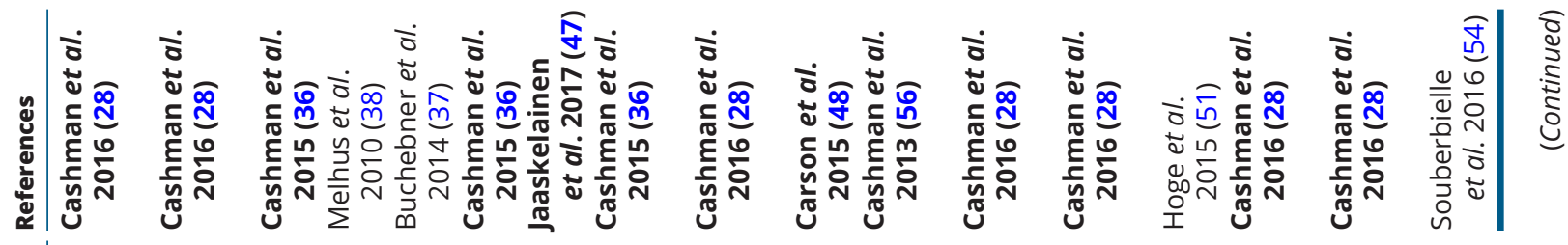

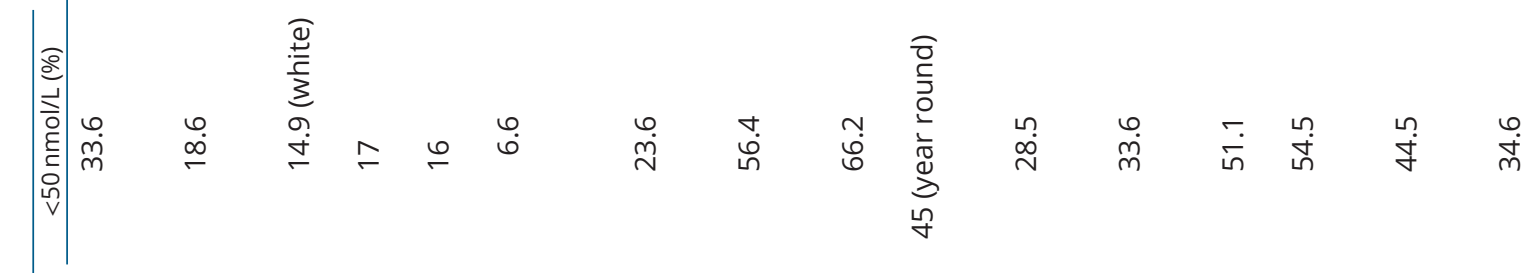

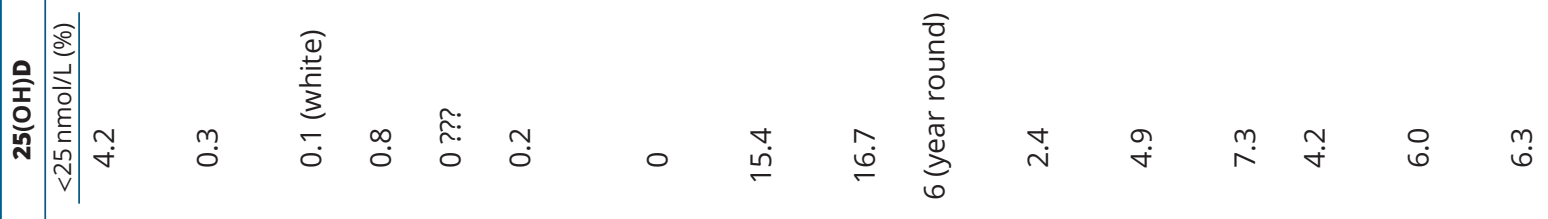

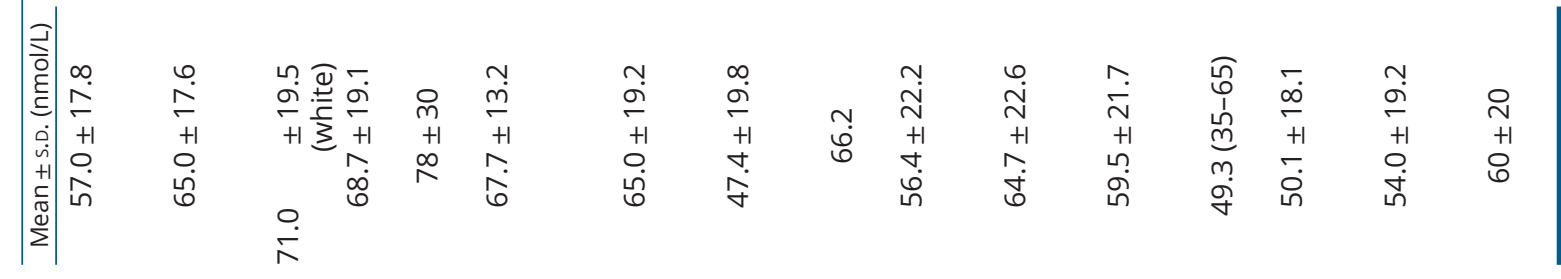

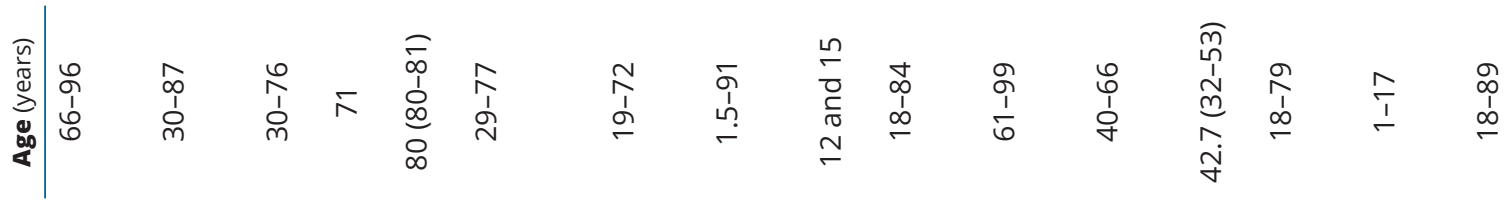

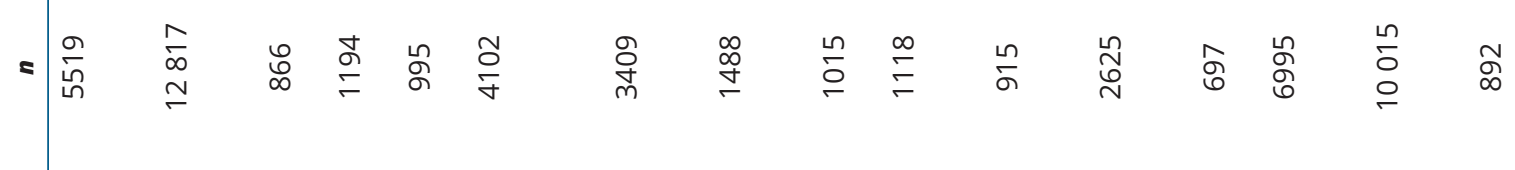

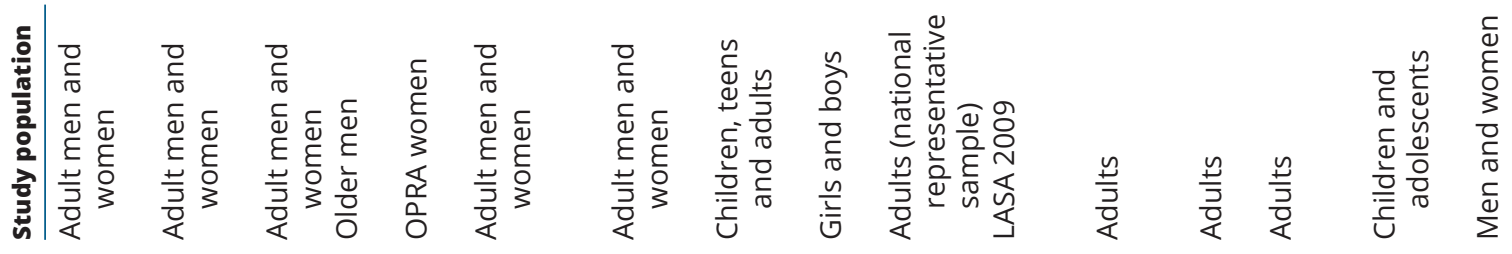

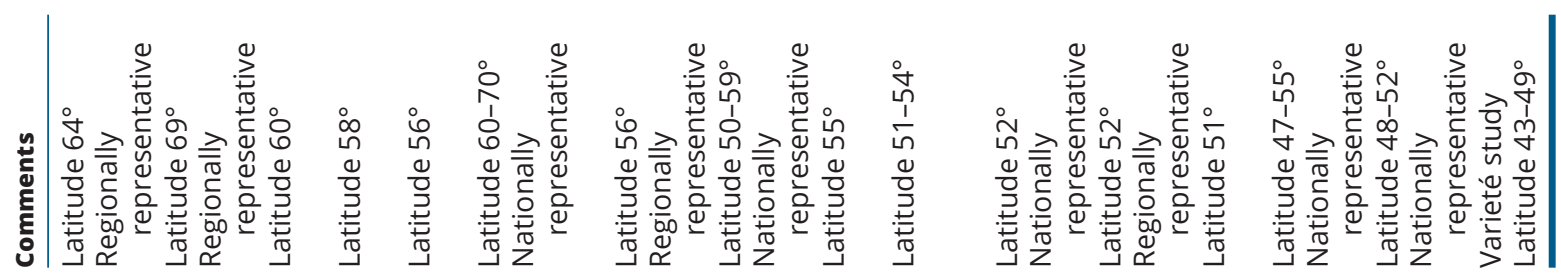




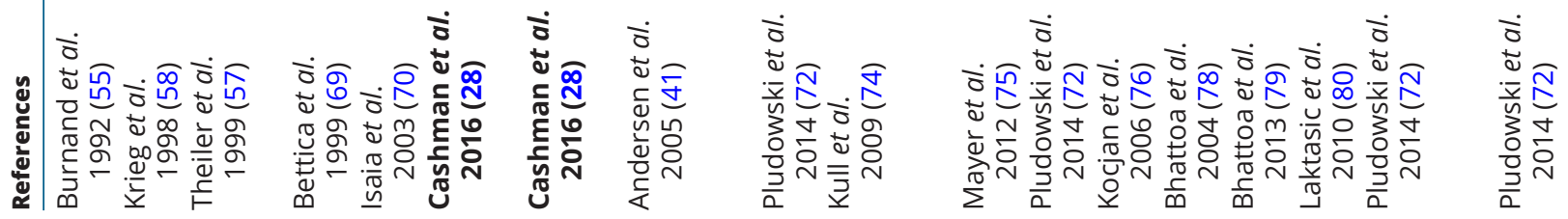

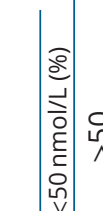

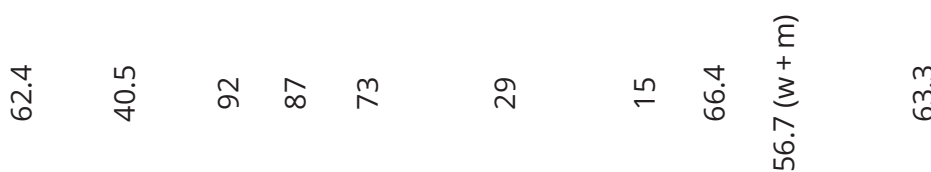

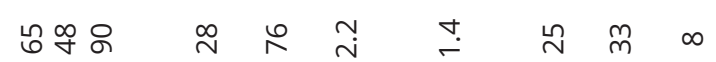

$-$

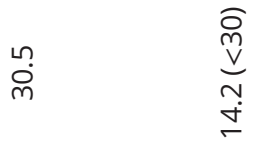

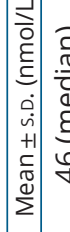

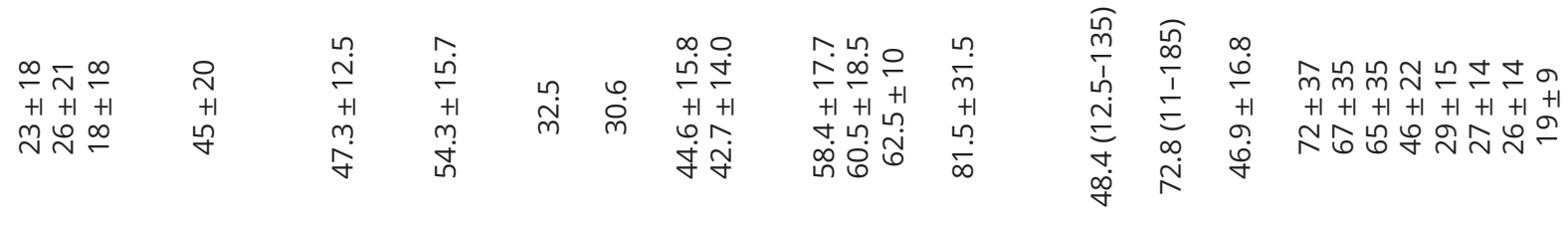

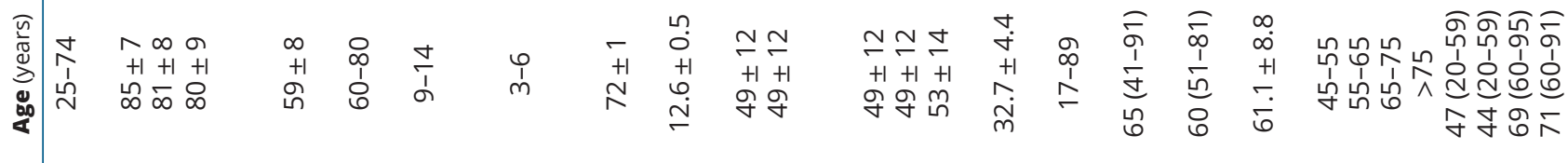

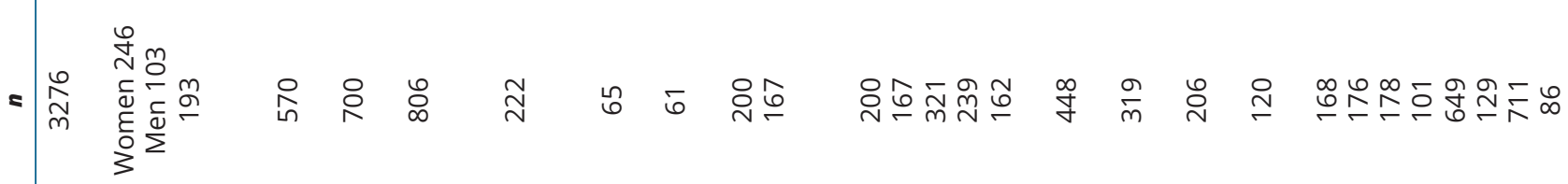
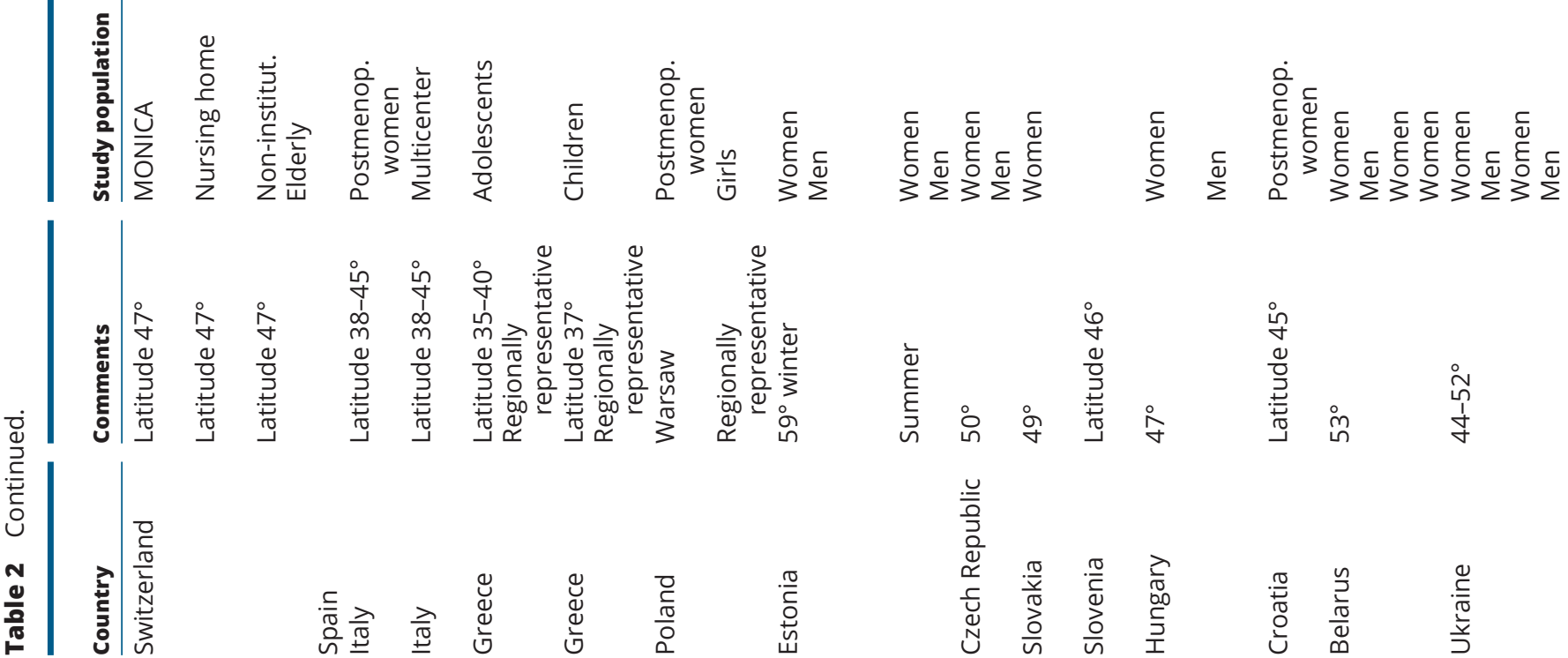

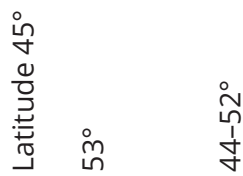

$\frac{.}{\frac{0}{0}}$

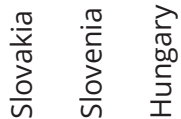

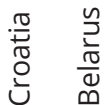

$\frac{\stackrel{0}{\frac{5}{0}}}{\frac{\sqrt{2}}{\frac{D}{2}}}$ 


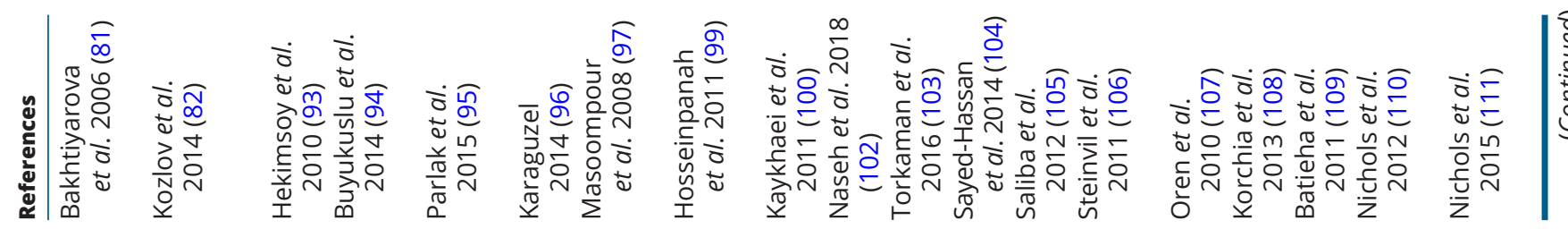

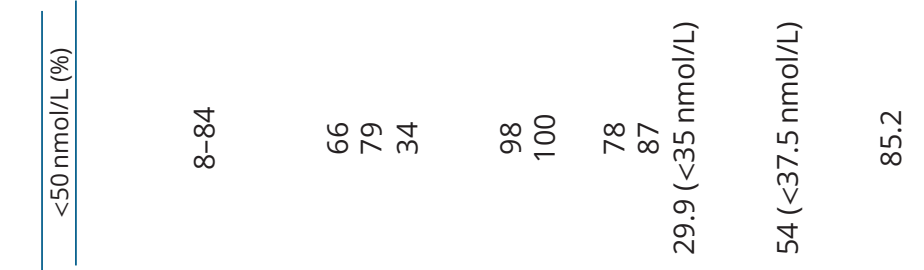

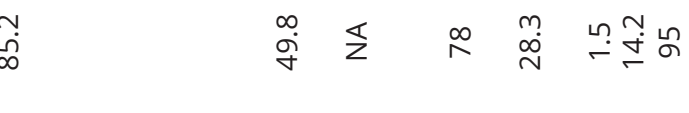

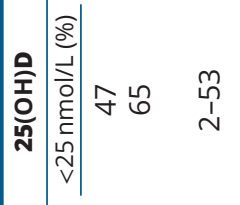

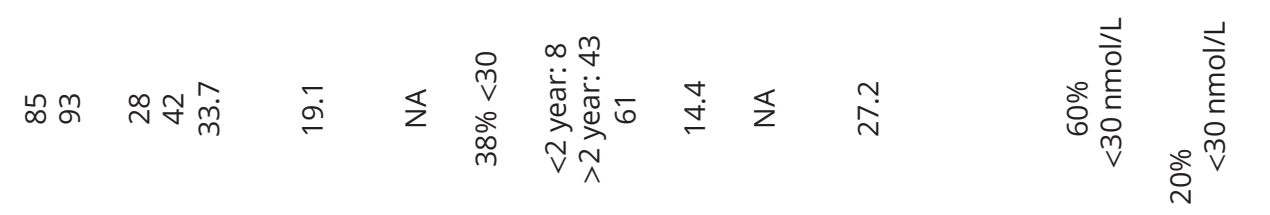

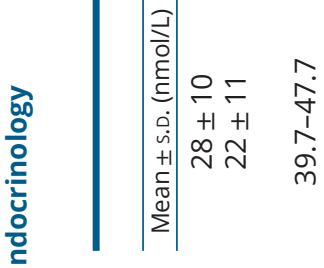

$\overbrace{n}^{+1}$

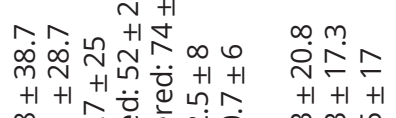

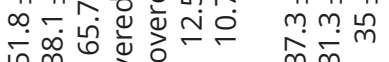

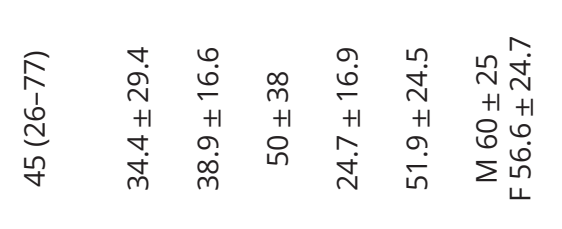

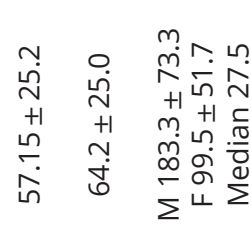

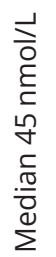

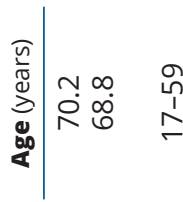

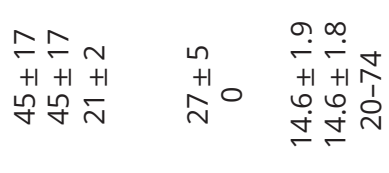

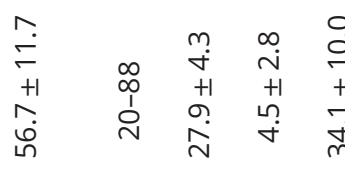

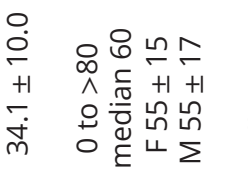

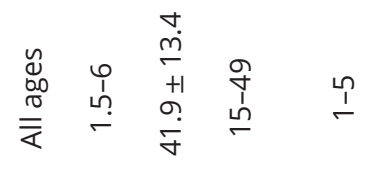

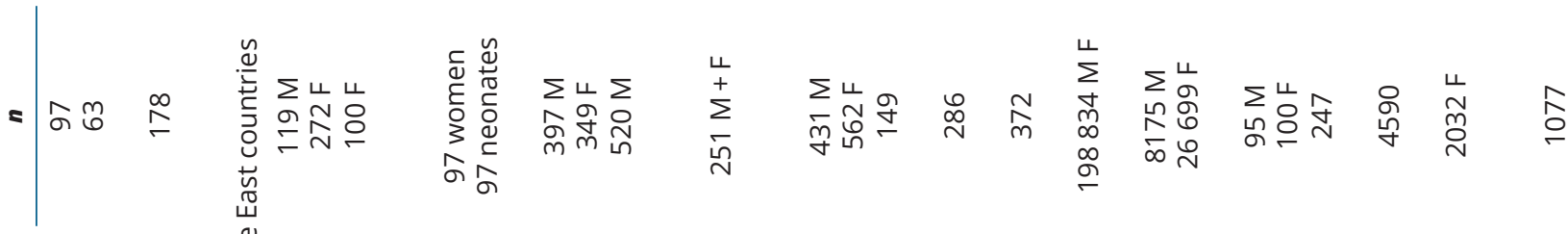

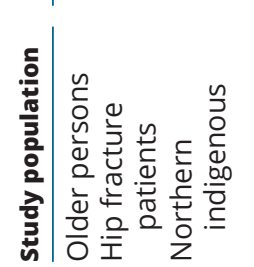

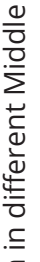

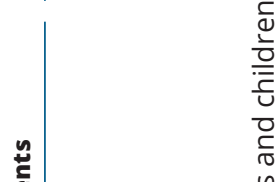
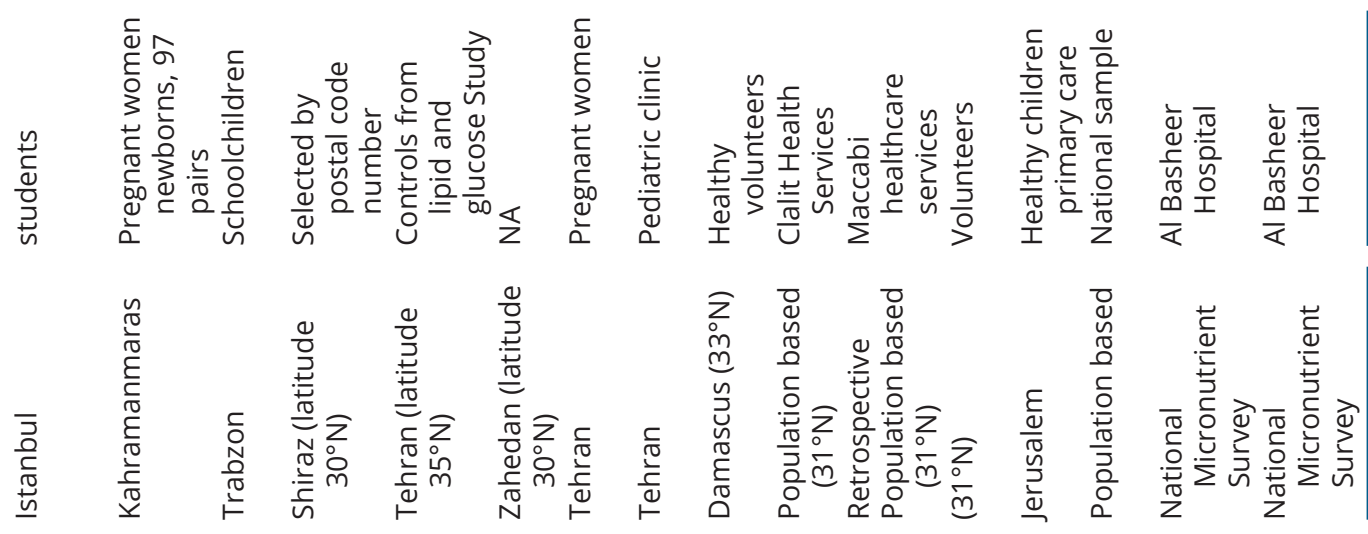

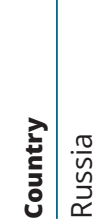

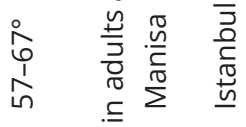

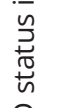

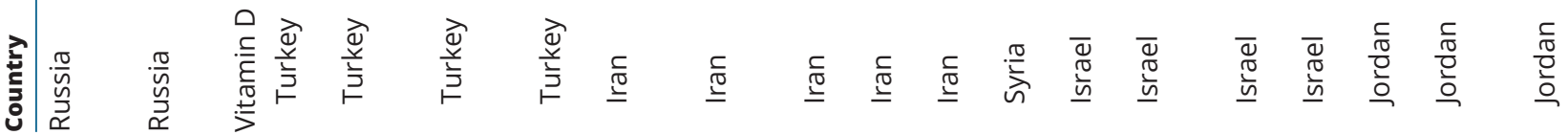




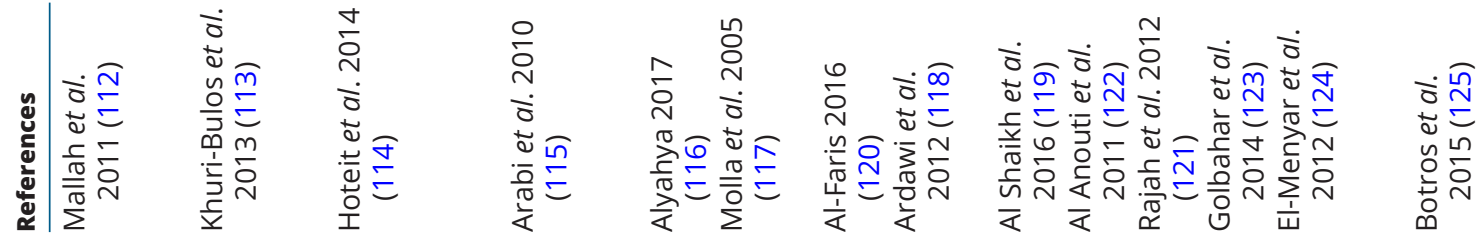

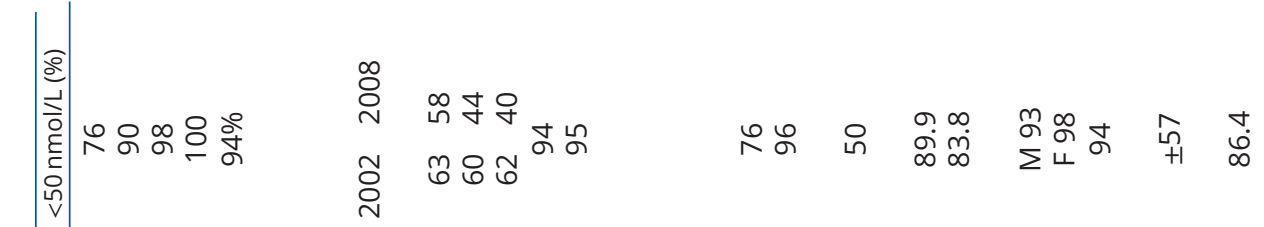

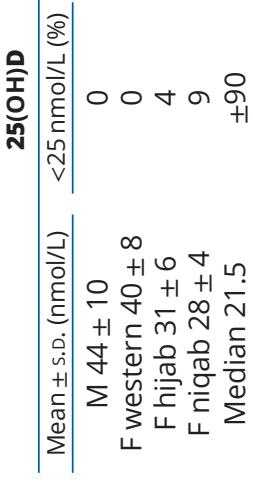

$\hat{m} \leftarrow 0$

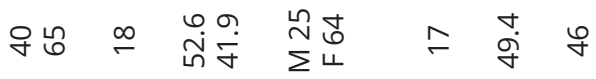

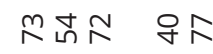

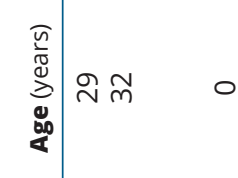

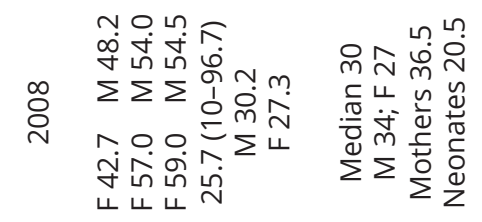

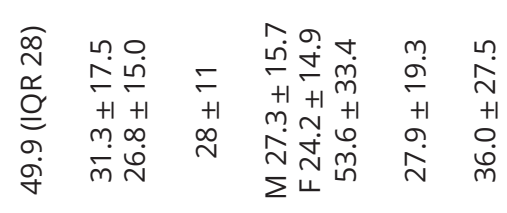

ำกำ ชิก

ㄴำํ..…

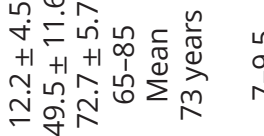

ำ

交

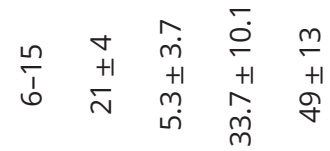

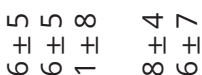

뉴ำ

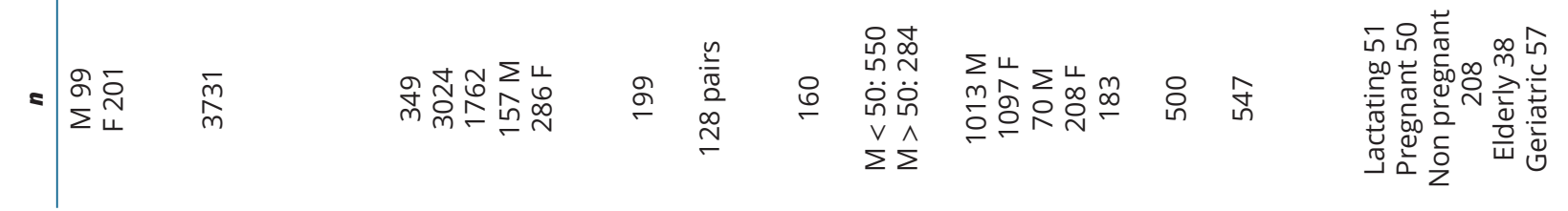
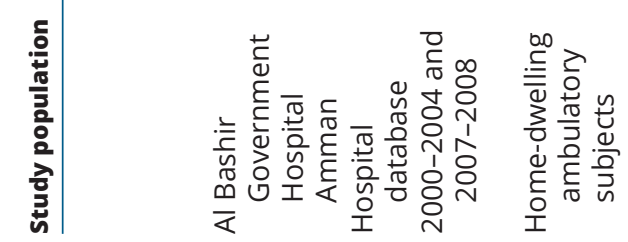

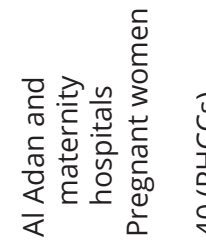
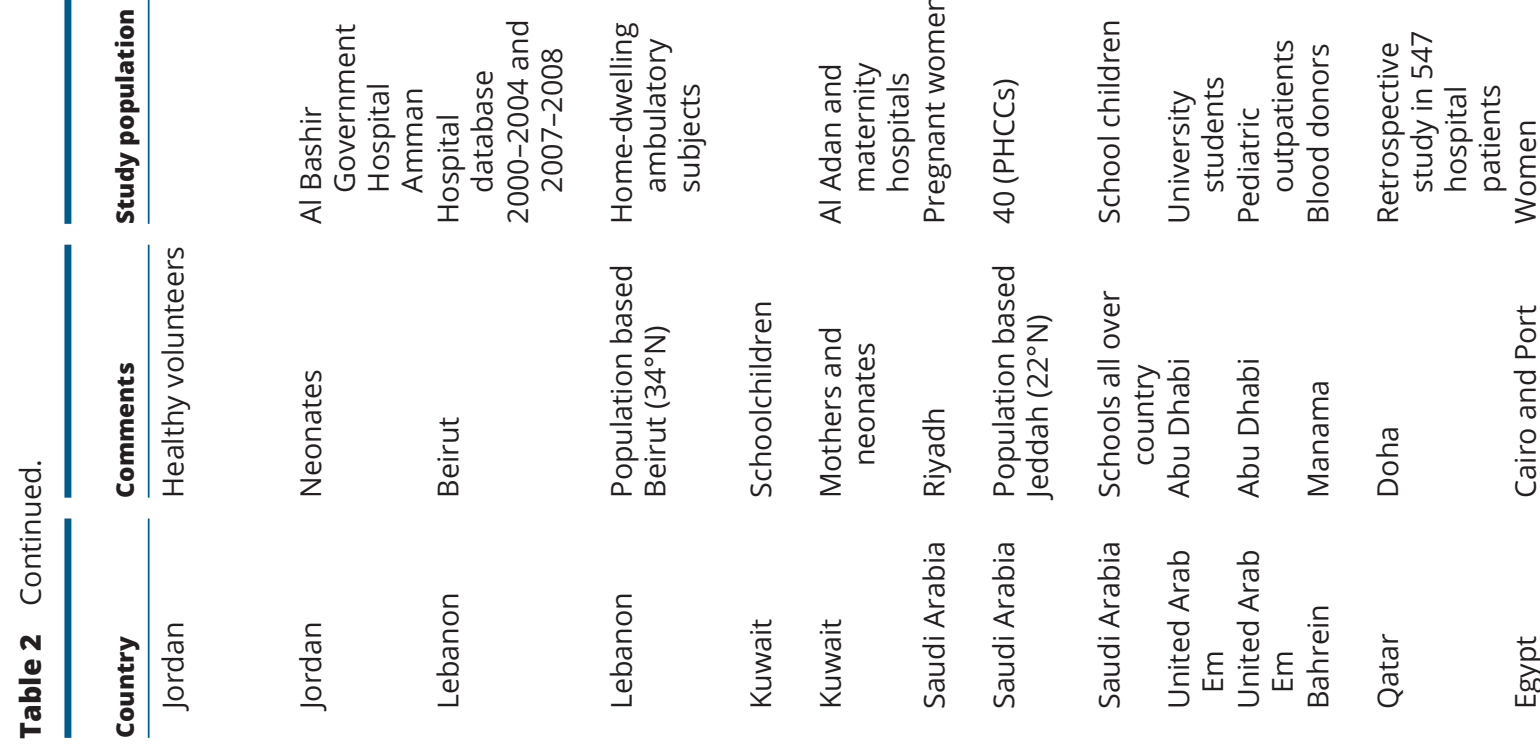

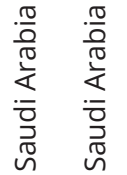

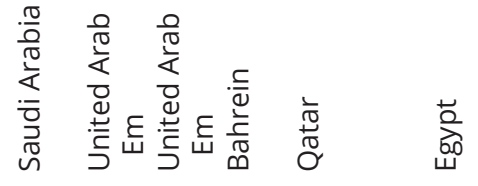




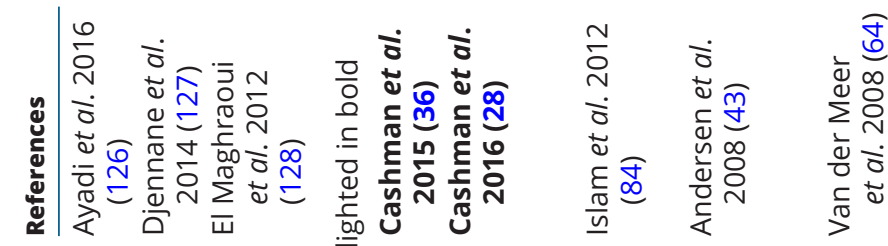

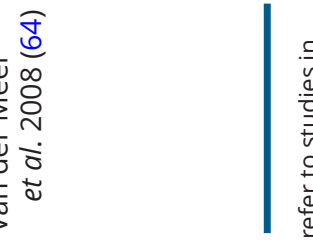

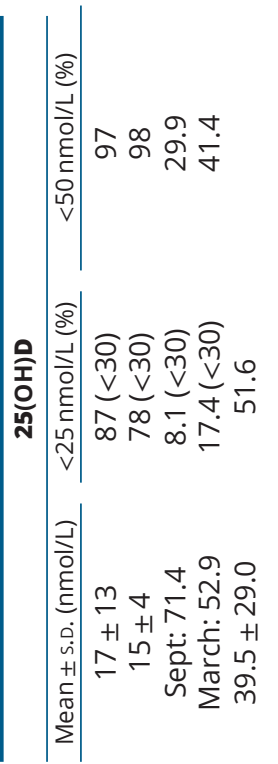

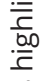

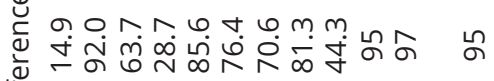

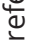

$\stackrel{\square}{\rightleftarrows}$

옹

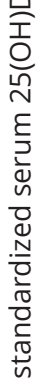

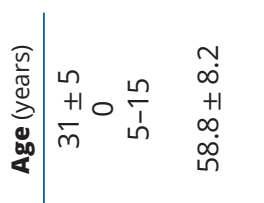

$\operatorname{lng} m 000-\infty-$

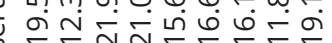

0
$0+1+1+1+1+1++1+10$
0

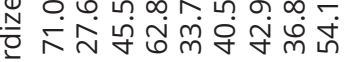

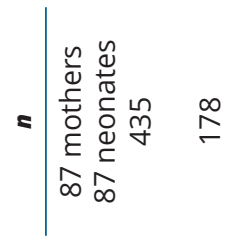

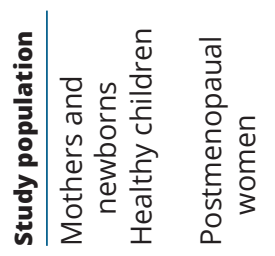

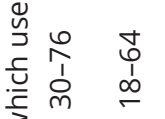

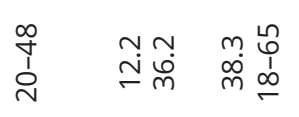

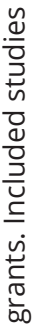

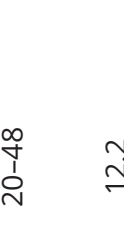

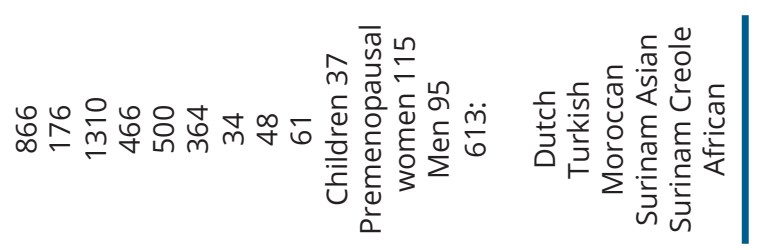

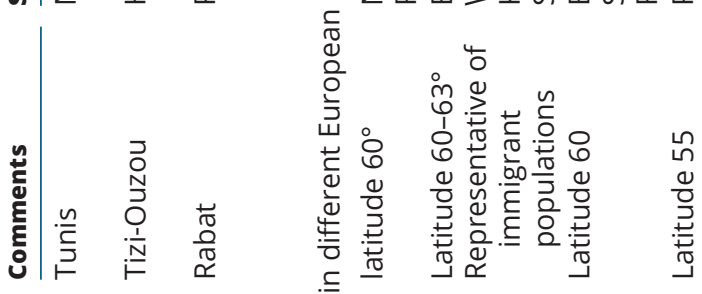

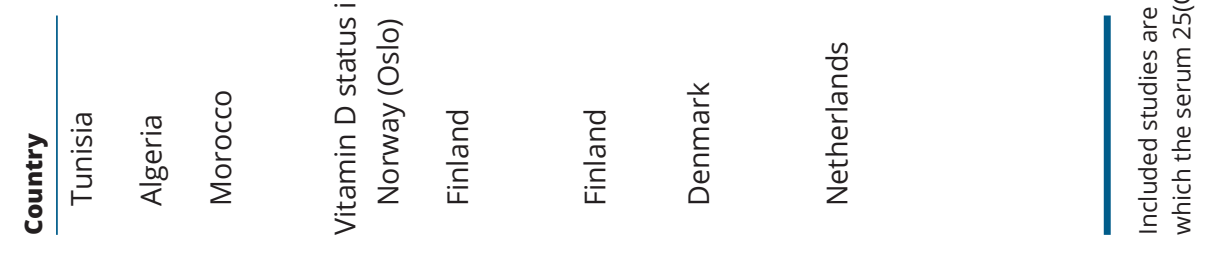




\section{Southern Europe}

Standardized data from adults are not available. An older European population-based study in older persons, the Seneca study, showed a mean serum $25(\mathrm{OH}) \mathrm{D}$ of $26 \mathrm{nmol} / \mathrm{L}$ in Spain, $39 \mathrm{nmol} / \mathrm{L}$ in Portugal, $28 \mathrm{nmol} / \mathrm{L}$ in Italy and $25 \mathrm{nmol} / \mathrm{L}$ in Greece while it was around $45 \mathrm{nmol} / \mathrm{L}$ in the Nordic countries (31). Other studies in these countries usually show mean serum 25(OH)D concentrations below $50 \mathrm{nmol} / \mathrm{L}$ and higher percentages of serum $25(\mathrm{OH}) \mathrm{D}$ $<30 \mathrm{nmol} / \mathrm{L}$ than in Northern and Western Europe $(67,68$, $69,70,71)$. Standardized data from infants and children in Greece (ODIN) showed serum $25(\mathrm{OH}) \mathrm{D}<30 \mathrm{nmol} / \mathrm{L}$ in $4.2-6.9 \%$, and $<50 \mathrm{nmol} / \mathrm{L}$ in $40.5-62.4 \%$ (28).

\section{Eastern Europe}

Standardized data from adults are not available. In general, a review and individual studies showed a mean serum 25(OH)D usually lower than $50 \mathrm{nmol} / \mathrm{L}$, and a poorer vitamin D status than in Northern and Western Europe $(72,73,74,75,76,77,78,79,80,81,82)$.

\section{Immigrants in Europe}

Studies from Norway, Finland, Denmark and the Netherlands confirm a very poor vitamin D status in nonWestern immigrants in European countries, in comparison with the locally born and with people in their country of origin $(43,64,65,83,84,85)$. A study in Dutch general practices showed a mean serum $25(\mathrm{OH}) \mathrm{D}$ of $30 \mathrm{nmol} / \mathrm{L}$ or lower in Turkish, Moroccan and Surinamese people in comparison with a mean serum $25(\mathrm{OH}) \mathrm{D}$ of $67 \mathrm{nmol} / \mathrm{L}$ in locally born people (64).

\section{European population studies}

As mentioned early, the Seneca study was performed in eight countries but serum 25(OH)D was measured in one central laboratory to avoid variation between different laboratories (31). Some studies reporting baseline data from randomized clinical trials in patients with osteoporosis also used a central laboratory facility, making comparisons between countries more reliable (raloxifene and bazedoxifene studies) $(86,87)$. A general trend in these data is that vitamin D status usually is much better in Nordic countries than around the Mediterranean. The European ODIN study used standardized data from epidemiological studies in Europe. Severe vitamin D deficiency (serum $25(\mathrm{OH}) \mathrm{D}<30 \mathrm{nmol} / \mathrm{L}$ ) was observed in
$12.5 \%$ of the participants and $40 \%$ was deficient (serum $25(\mathrm{OH}) \mathrm{D}<50 \mathrm{nmol} / \mathrm{L})(28)$.

\section{Vitamin D status and prevalence of vitamin D deficiency in the Middle East}

Population-based studies are rare. The prevalence of vitamin D deficiency and rickets is high in the Middle East despite abundant sunshine $(25,88,89,90,91,92)$ (Table 2). The median or mean serum $25(\mathrm{OH}) \mathrm{D}$ in almost all surveys was between 25 and $50 \mathrm{nmol} / \mathrm{L}$, with lower values in women than in men, that also depend on clothing style $(93,94,95,96,97,98,99,100,101,102$, 103, 104, 105, 106, 107, 108, 109, 110, 111, 112, 113, 114, $115,116,117,118,119,120,121,122,123,124,125,126$, $127,128,129,130,131)$. In a recent systematic review, the prevalence of vitamin D deficiency in the Middle East varied between 30 and 90\% depending on the type of study, country, age group and assay used (92). Vitamin D status was poor in several surveys in Saudi Arabia $(118,119)$, probably due to a very traditional lifestyle. Vitamin D status is better in Israel.

In general, vitamin $\mathrm{D}$ deficiency is much more prevalent in the Middle East than in Northern and Western Europe. Risk groups for severe deficiency include children, adolescents and pregnant women.

\section{Determinants of vitamin $D$ status and risk groups for vitamin D deficiency}

Demographic, anthropometric and lifestyle factors are robust predictors of rickets and poor vitamin D status worldwide in general, and in the Middle East in particular (Fig. 1). Sunshine exposure and vitamin D intake are the main determinants, but these are modified by other factors. Vitamin D status deteriorates with aging above 70 years due to decreased sun exposure and cutaneous synthesis (132), and is poor in the institutionalized, $75 \%$ of them being severely vitamin D deficient (serum $25(\mathrm{OH}) \mathrm{D}<25 \mathrm{nmol} / \mathrm{L})$, and in patients with hip fracture $(66,133)$. The good vitamin $\mathrm{D}$ status in the Nordic countries is explained by the frequent consumption of cod liver oil and vitamin D supplements $(134,135)$. Furthermore, fortification of milk and milk products over the last 10 years has considerably improved vitamin D status in Finland (47). On the other side, strong sunshine in Southern Europe and the Middle East may lead to decreased exposure (136), and skin pigmentation 


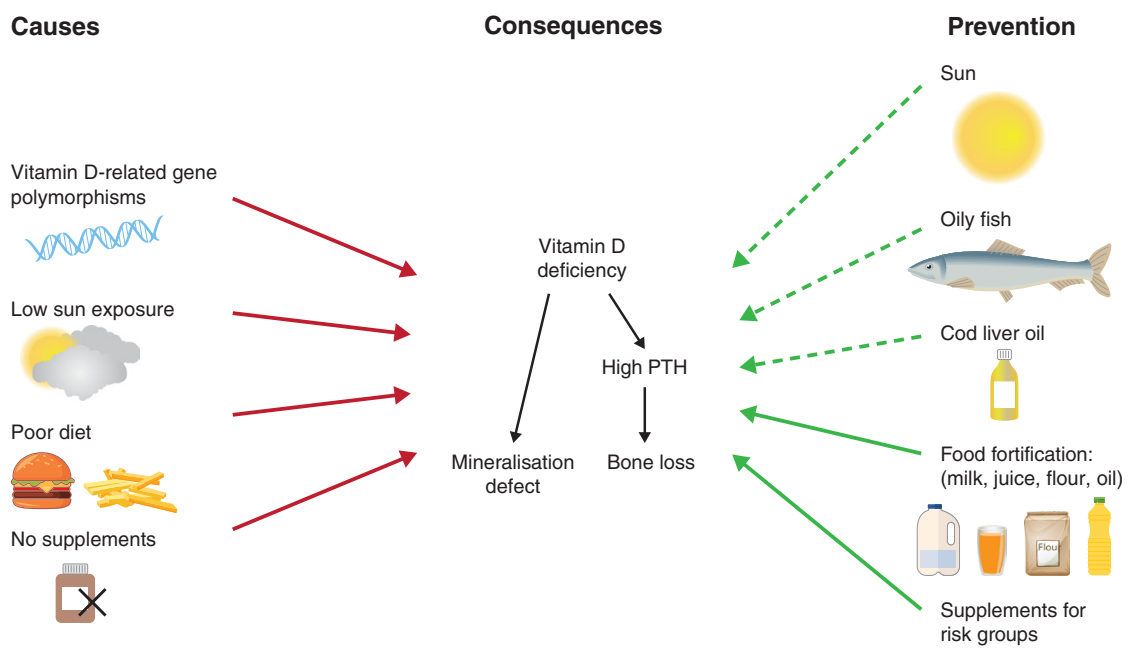

\section{Figure 1}

Causes, consequences and prevention of vitamin $\mathrm{D}$ deficiency. The red arrows lead to vitamin $\mathrm{D}$ deficiency, the green arrows can prevent it. Vitamin D-related gene polymorphisms indicate gene polymorphisms in the vitamin D metabolic pathway that decrease vitamin D bioavailability. Low sun exposure may also be due to clothing style, skin pigmentation and sunscreen use. Poor diet means no fish, no dairy products, no vitamin D-fortified foods. A full color version of this figure is available at https://doi. org/10.1530/EJE-18-0736.

decreases vitamin D synthesis (137). Vitamin D status in the Middle East is strongly dependent on clothing style, with decreasing vitamin D status going from Westernstyle clothing to hijab and niqab (129, 130, 131). A low calcium intake is common in the Middle East (92). It increases the risk of rickets, and it leads to secondary hyperparathyroidism and bone loss. Pollution and urban living are other factors.

Risk groups for vitamin D deficiency are children, adolescents, pregnant women and older persons. Vitamin D status usually is very poor in immigrants from non-Western countries, compared with native people $(28,64,83,84,85)$, fatty fish and supplements being the most important determinants (64). This is even worse in pregnant non-Western immigrants, who displayed mean serum 25(OH)D concentrations around $25 \mathrm{nmol} / \mathrm{L}(65)$.

\section{Vitamin D intake in Europe and the Middle East}

Measurements of vitamin D content of food requires special expertise due to its low concentration, the possible presence of vitamin $\mathrm{D}$ esters with uncertain bioavailability, and the presence of $25(\mathrm{OH}) \mathrm{D}$ in some food items. Most of the data presented below is based on methodology which estimated vitamin D only. Studies on vitamin D intake in Europe have been nicely summarized by Spiro and Buttriss (33), and Kiely and Black (138). An overview of the data is presented in Table 3.

\section{Northern Europe}

The mean intake of vitamin D in Northern Europe varies between 4 and $14 \mu \mathrm{g} /$ day $(41,43,139,140,141,142,143$, $144,145,146,147,148,149)$, with high values found in Norway, due to the consumption of oily fish and cod liver oil. In Iceland, the difference between users and nonusers of cod liver oil was more than $9 \mu \mathrm{g} /$ day. In Sweden, fish and fortified milk products were important sources. In Finland, the fortification of fluid milk products was recently increased to $10 \mu \mathrm{g} / \mathrm{L}$. Vitamin D supplement of $10 \mu \mathrm{g} /$ day was recommended for children younger than 3 years, and $7.5 \mu \mathrm{g} /$ day for children and adolescents aged 3-18 years. The recent Finrisk-Findiet survey has shown that the dietary vitamin $\mathrm{D}$ intake has increased to above $10 \mu \mathrm{g} /$ day in men and nearly as much in women $(47,147)$. The mean dietary vitamin $\mathrm{D}$ intake was around $3 \mu \mathrm{g}$ /day in Denmark.

\section{Western Europe}

The mean vitamin D intake in Western Europe varies between 1.5 and $5 \mu \mathrm{g} / \mathrm{day}$, far below the EAR of $10 \mu \mathrm{g} /$ day $(150,151,152,153,154,155,156,157,158$, $159,160,161)$.

\section{Southern Europe}

Food consumption surveys presented in Table 3 showed vitamin D intakes from below $1 \mu \mathrm{g}$ /day to about $3 \mu \mathrm{g}$ /day in Italy, Spain and Portugal. 
Table 3 Vitamin D intake in European and Middle East countries.

\begin{tabular}{|c|c|c|c|c|c|}
\hline Country & Study population & $n$ & Age (years) & Vitamin D intake ( $\mu \mathrm{g} /$ day) & References \\
\hline Iceland & & & & $\begin{array}{c}3.9 \mu \mathrm{g} \\
13.5 \mu \mathrm{g} \text { (with cod liver oil) }\end{array}$ & $\begin{array}{l}\text { Thorgeirsdottir et al. } \\
2012 \text { (139) }\end{array}$ \\
\hline Norway & $\begin{array}{l}\text { Volunteers } \\
\text { Norkost }\end{array}$ & 32 & & $\begin{array}{c}9.6 \mu \mathrm{g} \\
\mathrm{M}: 15 \mu \mathrm{g} \\
\mathrm{F}: 12.9 \mu \mathrm{g}\end{array}$ & $\begin{array}{l}\text { Brustad et al. } 2004 \text { (134) } \\
\text { Norkost (144) }\end{array}$ \\
\hline Sweden & Riksmaten & & & $7.1 \mu \mathrm{g}$ & Riksmaten (145) \\
\hline Finland & $\begin{array}{l}\text { National Diet Survey } \\
\text { Findiet }\end{array}$ & 1708 & $25-74$ & $\begin{array}{l}\text { M: } 11 \mu \mathrm{g} \\
\text { F: } 9 \mu \mathrm{g} \\
\text { OM: } 14 \mu \mathrm{g} \\
\text { OW: } 19 \mu \mathrm{g}\end{array}$ & Helldán et al. 2013 (147) \\
\hline Denmark & Dan Nat Survey & & & $\begin{array}{l}3.9 \\
3.1\end{array}$ & \\
\hline United Kingdom & $\begin{array}{l}\text { NDNS rolling survey } \\
(2008 / 2009 \text { to } \\
2009 / 2010)\end{array}$ & $\begin{array}{l}\text { M: } 210 \\
\text { M: } 238 \\
M: 346 \\
M: 96 \\
F: 213 \\
F: 215 \\
F: 461 \\
F: 128\end{array}$ & $\begin{array}{c}4-10 \\
11-18 \\
19-64 \\
>65 \\
4-10 \\
11-18 \\
19-64 \\
>65\end{array}$ & $\begin{array}{c}2.2 \text { (median) } \\
2.1 \\
2.8 \\
3.9 \\
2 \\
1.7 \\
2.6 \\
3.1 \text { (median) }\end{array}$ & $\begin{array}{l}\text { Department of Health } \\
2011 \text { (153) }\end{array}$ \\
\hline Ireland & $\begin{array}{l}\text { National Adult } \\
\text { Nutrition Survey }\end{array}$ & 1274 & $18-64$ & $\begin{array}{l}3.5 \text { (median) } \\
6.4 \text { (mean) }\end{array}$ & Black et al. 2015 (151) \\
\hline Ireland & $\begin{array}{l}\text { Irish Preschool Children } \\
\text { Survey }\end{array}$ & 500 & $1-4$ & 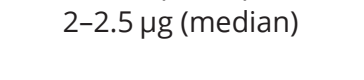 & $\begin{array}{l}\text { Hennessy et al. } \\
2016(152)\end{array}$ \\
\hline Ireland & $\begin{array}{l}\text { Irish Children's and } \\
\text { Teens' National } \\
\text { Nutrition Surveys }\end{array}$ & $\begin{array}{l}594 \\
441\end{array}$ & $\begin{array}{c}5-8 \\
9-12 \\
13-17\end{array}$ & $\begin{array}{l}1.9 \text { (median) } \\
2.1 \text { (median) } \\
2.4 \text { (median) }\end{array}$ & Black et al. 2014 (150) \\
\hline Netherlands & $\begin{array}{l}\text { Hip fract pat controls } \\
\text { Food cons survey }\end{array}$ & $\begin{array}{l}125 \\
74\end{array}$ & $\begin{array}{l}75.9 \\
75.6\end{array}$ & $\begin{array}{c}2.8 \\
2.9 \\
\text { M: } 4.8 \\
\text { F: } 3.6\end{array}$ & Lips et al. 1987 (156) \\
\hline Germany & Nat Nutr Survey & & & $\begin{array}{l}\text { M: } 4.4 \\
F: 3.4\end{array}$ & \\
\hline Portugal & Epiporto & & & $\begin{array}{l}M: 3.4 \\
F: 3.3\end{array}$ & $\begin{array}{l}\text { Spiro \& Buttriss } \\
2014 \text { (33) }\end{array}$ \\
\hline Spain & ENCAT 2002-2003 & & & $\begin{array}{l}\text { M: } 0.7 \\
F: 0.7\end{array}$ & $\begin{array}{l}\text { Spiro \& Buttriss } \\
2014(33)\end{array}$ \\
\hline Italy & INN-CA 1996 & & & $\begin{array}{l}M: 2.5 \\
F: 2.4\end{array}$ & $\begin{array}{l}\text { Spiro \& Buttriss } \\
2014(33)\end{array}$ \\
\hline $\begin{array}{l}10 \text { European } \\
\text { countries } \\
\text { (EPIC) }\end{array}$ & $\begin{array}{l}\text { European Prospective } \\
\text { Investigation into } \\
\text { Cancer and Nutrition }\end{array}$ & $\begin{array}{l}\text { M: } 13025 \\
\text { F: } 23009\end{array}$ & $\begin{array}{l}35-74 \\
35-74\end{array}$ & $\begin{array}{l}5.5 \\
3.6\end{array}$ & Jenab et al. 2009 (163) \\
\hline Southern & (EPIC) study & $\begin{array}{l}\text { M: } 4530 \\
\text { F: } 7372\end{array}$ & $\begin{array}{l}35-74 \\
35-74\end{array}$ & $\begin{array}{l}4.2 \\
5.1\end{array}$ & \\
\hline Central & & $\begin{array}{l}\text { M: } 3807 \\
\text { F: } 8561\end{array}$ & $\begin{array}{l}35-74 \\
35-74\end{array}$ & $\begin{array}{l}4.7 \\
3.4\end{array}$ & \\
\hline Northern & & $\begin{array}{l}\text { M: } 4688 \\
\text { F: } 7076\end{array}$ & $\begin{array}{l}35-74 \\
35-74\end{array}$ & $\begin{array}{l}7.4 \\
5.0\end{array}$ & \\
\hline \multicolumn{6}{|l|}{ Middle East } \\
\hline Turkey & Mining facility & 135 coal miners & $32.6 \pm 7.4$ & $2.1 \pm 1.3$ & Bilici et al. 2016 (164) \\
\hline Iran & $\begin{array}{l}\text { Tehran Lipid and } \\
\text { Glucose Study }\end{array}$ & 5524 & $18-70$ & $\begin{array}{l}M: 2.5 \pm 4.3 \\
F: 3.8 \pm 3.1\end{array}$ & $\begin{array}{l}\text { Ejtahed et al. } \\
2016(165)\end{array}$ \\
\hline Iran & $\begin{array}{l}\text { Iranian Multicentric } \\
\text { Osteoporosis Study }\end{array}$ & F: 581 & $42.4 \pm 12.2$ & $1.5 \pm 1.2$ & $\begin{array}{c}\text { Khashayar et al. } \\
2017(166)\end{array}$ \\
\hline Iran & & $\begin{array}{l}\text { Pregnant } \\
\text { women }\end{array}$ & & $2.3 \pm 1.9$ & $\begin{array}{l}\text { Sabour et al. } \\
2006 \text { (167) }\end{array}$ \\
\hline Iran & & Children & & 1.4 & Feizabad et al. 2017 (168) \\
\hline
\end{tabular}


Table 3 Continued.

\begin{tabular}{|c|c|c|}
\hline Country & Study population & $n$ \\
\hline Iran & & 100 children \\
\hline Kuwait & Repres. national sample & 1049 \\
\hline Lebanon & Beirut & $\begin{array}{l}\mathrm{F} \\
\mathrm{M}\end{array}$ \\
\hline Lebanon & & $\begin{array}{l}128 \text { pregnant } \\
\text { women }\end{array}$ \\
\hline Qatar & & $\begin{array}{l}60 \text { young } \\
\text { women }\end{array}$ \\
\hline $\begin{array}{l}\text { United Arab } \\
\text { Emirates }\end{array}$ & & $\begin{array}{l}350 \text { adolescent } \\
\text { females }\end{array}$ \\
\hline Saudi Arabia & $\begin{array}{l}\text { University students } \\
\text { Tabuk }\end{array}$ & \\
\hline Tunisia & & 225 boys \\
\hline Tunisia & & $\begin{array}{l}87 \text { pregnant } \\
\text { women }\end{array}$ \\
\hline
\end{tabular}

\begin{tabular}{|c|c|}
\hline Age (years) & Vitamin D intake ( $\mu \mathrm{g} /$ day) \\
\hline $4-10$ & $\begin{array}{c}11.7 \\
1-2.9\end{array}$ \\
\hline $39.4 \pm 5.6$ & $2.2 \pm 1.5$ \\
\hline $41.3 \pm 5.5$ & $\begin{array}{c}3.2 \pm 2.0 \\
10.6 \pm 10.9 \text { (FFQ) } \\
8.9 \pm 2.5 \text { ( } 24 \text { h recall })\end{array}$ \\
\hline 29 & 3.0 \\
\hline $15.3 \pm 2$ & 8.5 \\
\hline $19-25$ & $53 \%<15 \mu \mathrm{g} /$ day \\
\hline & $\begin{array}{c}8 \\
2.2\end{array}$ \\
\hline
\end{tabular}

\begin{tabular}{l} 
References \\
\hline Kelishadi et al. 2014 (169) \\
Zaghloul et al. 2013 (170) \\
Gannage-Yared et al. \\
$\quad 2000$ (171) \\
Papazian et al. 2016 \\
$\quad(172)$ \\
Salameh et al. 2016 (173) \\
Narchi et al. 2015 (174) \\
Alzaheb \& Al-Amer \\
2017 (175) \\
Bezrati et al. $2016(176)$ \\
Ayadi et al. 2016 (126)
\end{tabular}

M, male; F, female; OM, older male; OF, older female.

\section{Eastern Europe}

The mean vitamin $\mathrm{D}$ intake varied between 2 and $5 \mu \mathrm{g} /$ day, according to a recent review (162).

\section{European studies}

National dietary and food consumption surveys as well as smaller studies use various methods of data collection, analysis and reporting, making meaningful comparison of vitamin D intakes problematic (155). Some studies compared different countries with the same methods. A European study done in Denmark, Finland, Ireland and Poland found a mean vitamin D intake of 2.4-5.0 $\mu \mathrm{g} /$ day in girls and 3.4-9.5 $\mu \mathrm{g}$ /day in older women (41)

The European Prospective Investigation into Cancer and Nutrition (EPIC) compared vitamin D intakes in ten European countries. The mean vitamin D intake was 5.5 and $3.6 \mu \mathrm{g} / \mathrm{day}$ in men and women respectively with the highest intake in the Northern countries (163).

In conclusion, mean vitamin $\mathrm{D}$ intake in most European countries is rather low, in most countries less than $5 \mu \mathrm{g} /$ day (200IU/day). Vitamin D intake is highest in the Nordic countries and poor in Southern Europe.

\section{Vitamin D intake in the Middle East}

Population-based studies on vitamin D intake are scarce. The used food frequency and $24 \mathrm{~h}$ recall questionnaires varied and these tools were mostly validated in Western populations, with little or no adaptation to the Mediterranean/Middle Eastern diet. Vitamin D fortification varies widely between countries, as detailed

in the section on Food fortification with vitamin D. These drawbacks may explain the wide variability between countries and the lack of a consistent pattern by age. The mean vitamin D intake ranged between 1 and $4 \mu \mathrm{g}$ / day, with some exceptions in selected groups of children, adolescents and pregnant women, probably due to vitamin D supplements (126, 164, 165, 166, 167, 168, $169,170,171,172,173,174,175,176)$. These intakes are well below the RDA of 10-20 $\mu \mathrm{g} /$ day, depending on age and reproductive stage $(2,177)$.

\section{Genetic factors}

Genetic factors may contribute to up to $28 \%$ of interindividual variability in serum $25(\mathrm{OH}) \mathrm{D}$ concentrations, while clinical correlates such as season, vitamin D intake and waist circumference explain another $24 \%$ of variability (178). Studies have applied the candidate gene approach to relatively common single nucleotide polymorphisms which play an important biological role in vitamin D metabolism, transport, degradation and downstream pathways, to evaluate their impact on circulating $25(\mathrm{OH})$ $\mathrm{D}$ concentrations (Fig. 1). These include genes involved in cholesterol synthesis (DHCR7), 1- $\alpha$-hydroxylase (CYP27B1), 25-hydroxylase (CYP2R1), vitamin D transport (GC (group specific component), identical to DBP) and to a lesser extent also 24-hydroxylase (CYP24A1) (179, 180, $181,182)$. Similar effects of polymorphisms of these genes (especially DBP/GC) were confirmed in several studies (183). The combined effects of these genes do not explain more than about $5 \%$ of the variability and considerably less than the seasonal variation in serum $25(\mathrm{OH}) \mathrm{D}(179,184)$. 
$25(\mathrm{OH}) \mathrm{D}$ and all other metabolites of vitamin $\mathrm{D}$ are bound to a high capacity, high affinity serum DBP or GC. A smaller proportion is loosely bound to albumin. Therefore the free concentration of $25(\mathrm{OH}) \mathrm{D}$ represents less than $0.1 \%$ of the total concentration. Genetic polymorphisms of DBP are associated with different DBP concentrations but this depends on the antibody used for measuring DBP. When polyclonal anti-DBP antibodies are used, subjects with GC2 genotype have a slightly lower DBP concentration compared to others (185), associated with lower $25(\mathrm{OH}) \mathrm{D}$ concentrations. A monoclonal antibody method found much (about 50\%) lower DBP concentrations in GC 1f-1f homozygotes (mainly AfricanAmericans) than in subjects with other genotypes (186). Subsequent studies using mass spectrometry to measure serum DBP, however, did not find a significant difference in DBP according to race $(187,188)$, creating serious doubt (189) on the conclusions based on the monoclonal antibody (186). As the free concentration of $25(\mathrm{OH}) \mathrm{D}$ is dependent on both DBP concentration and affinity it is yet not possible to conclude whether clinical correlates and thresholds for vitamin D deficiency depend on genetic polymorphisms of DBP. An assay to measure the free $25(\mathrm{OH}) \mathrm{D}$ concentration is available, but currently it is uncertain whether the measurement of this metabolite in its free state has clinical implications $(189,190)$.

\section{Impact of vitamin D on bone}

A beneficial effect of vitamin D on musculoskeletal health is well established, as severe vitamin D deficiency causes rickets in children and osteomalacia in adults. While rickets is rare in almost all European countries, it is still reported in the Middle East, in some Asian countries and in immigrants of those countries in Europe (88). In general, rickets in Europe is mostly reported in non-Western immigrants, mainly coming from Africa and Asia and in persons consuming macrobiotic or vegan diets $(191,192)$. This can be explained by the fact that oily fish and dairy products are the major dietary source of vitamin D and calcium, both being absent in these diets. Milder vitamin $\mathrm{D}$ deficiency results in secondary hyperparathyroidism, increased bone turnover and accelerated bone loss, osteoporosis and fractures (66). The vitamin D endocrine system primarily tries to maintain a normal serum calcium homeostasis whereby its role on bone can be either beneficial or deleterious depending on calcium intake and availability (193, 194). Many cross-sectional studies and especially randomized controlled trials have demonstrated a beneficial role of vitamin $\mathrm{D}$ supplementation, in a sufficient dose of daily $20 \mu \mathrm{g}$ (800 IU) vitamin D $(195,196$, 197) and in combination with calcium supplements (198, 199), among seniors (institutionalized and communitydwelling) at risk for vitamin D deficiency and with a lower than recommended calcium intake, showing a reduction of falls as well as hip and other fractures (3, $195,196,197,200)$. This conclusion has been reached in most $(195,201)$ but not all meta-analyses $(202,203,204)$. Whether such supplements would be beneficial for bone health in adolescents and non-elderly adults requires additional controlled intervention studies. The 2018 meta-analysis on the musculoskeletal benefits of vitamin D monotherapy on BMD, fractures and falls by Bolland

Table 4 Dietary reference intakes for vitamin D in $\mu$ g/day according to different European countries, the Institute of Medicine and the Endocrine Society.

\begin{tabular}{|c|c|c|c|c|c|c|c|c|}
\hline & $<1$ year & 1-3 years & 4-10 years & 11-18 years & Adults & Older & Pregnant & References $^{*}$ \\
\hline Nordic NR & 10 & 10 & 10 & 10 & 10 & 20 & 20 & NORDEN 2014 (144) \\
\hline UK & $8.5-10$ & 10 & 10 & 10 & 10 & 10 & 10 & SACN 2015 (30) \\
\hline Ireland & $7.0-8.5$ & 10 & $0-10$ & $0-15$ & $0-10$ & 10 & 10 & FSAI 1999*** \\
\hline Netherlands & 10 & 10 & $0-10$ & $0-10$ & $0-10$ & 20 & 10 & Weggemans et al. 2013 (249) \\
\hline Belgium & 10 & 10 & 10 & $10-15$ & $10-15$ & 15 & 20 & Spiro and Buttriss 2014 (33) \\
\hline France & $20-25$ & 10 & 5 & 5 & 5 & 5 & 10 & Spiro and Buttriss 2014 (33) \\
\hline $\mathrm{DACH}$ & 10 & 20 & 20 & 20 & 20 & 20 & 20 & Spiro and Buttriss 2014 (33) \\
\hline Spain & 10 & 15 & 15 & 15 & 15 & 20 & 15 & Spiro and Buttriss 2014 (33) \\
\hline Central Europe & 10 & $15-25$ & $15-25$ & $15-25$ & $20-50$ & $20-50$ & $20-50$ & Pludowski et al. 2013 (269) \\
\hline EFSA 2016 & 10 & 15 & 15 & 15 & 15 & 15 & 15 & EFSA 2016 (29) \\
\hline $\begin{array}{l}\text { Institute of } \\
\text { Medicine }\end{array}$ & 10 & 15 & 15 & 15 & 15 & 20 & 15 & IOM 2011 (2) \\
\hline $\begin{array}{c}\text { Endocrine } \\
\text { Society }\end{array}$ & $10-25$ & $15-25$ & $15-25$ & $15-25$ & $37.5-50$ & $37.5-50$ & $\begin{array}{l}15-25 * * \\
37.5-50\end{array}$ & Holick et al. 2011 (1) \\
\hline
\end{tabular}

https://eje.bioscientifica.com 
and colleagues suggests no benefit on these outcomes, but they did not analyze clinical trials with vitamin $\mathrm{D}$ and calcium vs double placebo (205).

\section{Extra-skeletal health}

The presence of the vitamin $\mathrm{D}$ receptor (VDR) in most cells and tissues, as well as the expression of the $1 \alpha$-hydroxylation enzyme CYP27B 1 in many cells and the large number of genes under the control of $1 \alpha, 25(\mathrm{OH})_{2} \mathrm{D}$ suggest a broader role of the vitamin $\mathrm{D}$ endocrine system beyond bone and calcium homeostasis $(206,207,208)$. Moreover, such potential effects on non-classical or nonskeletal outcomes are in line with data from association studies between low vitamin D status and cardiovascular diseases, diabetes and the metabolic syndrome, inflammatory, infectious and immune disorders, as well as a variety of cancers. A low vitamin D status was also associated with increased mortality risks as extensively reviewed $(3,27,206,209)$. Whether skeletal or cardiac muscles are target tissues for the vitamin $\mathrm{D}$ endocrine system has been debated. The presence of the VDR in skeletal muscle tissue has been questioned recently by Wang and DeLuca suggesting that the VDR is undetectable in muscle tissue (210), in contrast with many earlier studies (211, 212, 213, 214, 215), including the most recent one using a new multi-step immunofluorescent technique to detect the VDR in muscle biopsy tissue from older female subjects (216). Recently, others found VDR to be expressed albeit at low (mRNA and protein) levels (217). VDR null mice (systemic or cardiac muscle-specific deletion), however, show a clear muscle phenotype and many in vitro studies also show clear coherent positive effects of $1 \alpha, 25(\mathrm{OH}) 2 \mathrm{D}$ on muscle cell precursors. Severe vitamin D deficiency is frequently associated with muscle weakness/hypotonia and an increased risk of falling (218). Several double-blind intervention studies also show a significant average reduction of $19 \%$ in fall frequency when elderly vitamin $\mathrm{D}$ deficient subjects receive a vitamin D supplement, but meta-analyses of these studies came to divergent conclusions depending on the quality of fall assessment, and the inclusion of trials with or without blinding $(2,219,220)$. The overall interpretation of the presently available data suggest that correction of severe vitamin D deficiency improves muscle function and reduces the risk of falls $(3,220)$. High intermittent dosing of vitamin D or doses resulting in high serum $25(\mathrm{OH}) \mathrm{D}$ levels (above $125 \mathrm{nmol} / \mathrm{L}, 50 \mathrm{ng} / \mathrm{mL}$ ) may, however, result in increased risk of falls $(221,222)$ so that the therapeutic range for serum $25(\mathrm{OH}) \mathrm{D}$ and fall prevention may be between 50 and $75 \mathrm{nmol} / \mathrm{L}$ ( 20 and $30 \mathrm{ng} / \mathrm{mL}$ ) for optimal fall prevention (222). Based on current evidence, this range is safely reached with a vitamin D intake of $20 \mu \mathrm{g}$ (800 IU) per day (223) or $600 \mu \mathrm{g}$ (24 000 IU) per month $(222,224)$. Among somewhat younger postmenopausal women (mean age 66 year), a most desirable range of serum 25(OH)D for optimal fall prevention was suggested to be $80-95 \mathrm{nmol} / \mathrm{L}(32-38 \mathrm{ng} / \mathrm{mL})$ based on a multidose vitamin D trial (225). Notably, both trials suggested that a serum $25(\mathrm{OH}) \mathrm{D}$ higher than $113 \mathrm{nmol} / \mathrm{L}(45 \mathrm{ng} / \mathrm{mL})$ was associated with a significantly increased risk of falling compared to a $25(\mathrm{OH}) \mathrm{D}$ range of $80-95 \mathrm{nmol} / \mathrm{L}(221)$.

An additional aspect with potential impact on muscles and falls as well as bone density is the relationship between vitamin $\mathrm{D}$ status and sex steroid levels in men with a parallel seasonal variation of both hormones $(226,227$, $228,229)$. While it has been demonstrated that vitamin D increases testosterone production in human primary testicular cells (230), clinical trials were controversial $(231,232)$ and a pooled analysis did not show an increase (233). Meta-analyses of RCTs on cardiovascular outcomes, and glycaemic control and type 2 diabetes have shown disappointing effects $(208,234,235,236)$. This was confirmed by a Mendelian randomization study (237). However, a recent meta-analysis of RCTs of vitamin D on acute respiratory infection showed that vitamin $\mathrm{D}$ in a daily or weekly dose reduced the risk of acute respiratory infection by $12 \%$, the results being larger in those with baseline serum $25(\mathrm{OH}) \mathrm{D}<25 \mathrm{nmol} / \mathrm{L}$ (238). A large 4 year RCT of vitamin D $2000 \mathrm{IU} /$ day and calcium $1500 \mathrm{mg} /$ day in postmenopausal women showed a borderline $(P=0.06)$ decrease in cancer incidence (239). A recent Mendelian randomization study showed an association between genetically lowered serum 25(OH)D concentrations and higher ovarian cancer susceptibility (240).

In Mendelian randomization studies, the use of $25(\mathrm{OH})$ D measurements in relation to GC, CYP2R1, DHCR7 genotypes and a binary study outcome variable such as mortality has revealed associations of genotypes with $25(\mathrm{OH}) \mathrm{D}$ concentrations, and of $25(\mathrm{OH}) \mathrm{D}$ concentrations and mortality, but the statistical association of genotypes and binary outcome mortality was ambiguous (241). Thus, a direct influence of genotypes on clinical outcomes was not always visible (208). Further studies on mortality causes and low vitamin D status showed an association with cancer and all-cause mortality but not with cardiovascular mortality (241).

Recently, the results of two megatrials have become available. The VIDA trial in 5110 subjects compared 
vitamin D 100 000IU/month with placebo and found no effect of vitamin D on cardiovascular disease (242). The VITAL trial comparing vitamin D 2000IU/day with placebo in more than 25000 subjects, concluded that vitamin $\mathrm{D}$ did not result in a lower incidence of invasive cancer or cardiovascular events than placebo (243). The baseline mean serum $25(\mathrm{OH}) \mathrm{D}$ was rather high in these trials, 63 and $75 \mathrm{nmol} / \mathrm{L}$, respectively. From all this data, it can be concluded that the prevention of chronic diseases is not a reason to start vitamin $\mathrm{D}$ supplementation in a vitamin D replete population (244).

\section{Optimal levels of 25-hydroxyvitamin D}

Although a great degree of consensus exists concerning the essential role of vitamin D on bone health, and some controversy on its effect on muscle strength and falls, there is less consensus about the optimal or required concentration of $25(\mathrm{OH}) \mathrm{D}$ to achieve these effects. As there is no proven causality for the frequent association between vitamin $\mathrm{D}$ status and many other extra-skeletal effects, no threshold concentration can be defined for these putative protective effects.

The ECTS Working Group has defined severe vitamin $\mathrm{D}$ deficiency as a serum 25(OH)D lower than $30 \mathrm{nmol} / \mathrm{L}$ $(12 \mathrm{ng} / \mathrm{mL})$ as such concentrations and even more so concentrations below $15 \mathrm{nmol} / \mathrm{L}$ are associated with rickets or osteomalacia (245). The ECTS has defined vitamin $\mathrm{D}$ deficiency as a serum $25(\mathrm{OH}) \mathrm{D}$ concentration below $50 \mathrm{nmol} / \mathrm{L}$, a concentration that according to the IOM covers the needs of nearly all healthy individuals in the population in relation to bone health (2) (see 'Definitions' section), similar to the EFSA (29). In contrast, an extensive analysis in the UK (30) concluded that serum $25(\mathrm{OH}) \mathrm{D}$ concentrations should be above $25 \mathrm{nmol} / \mathrm{L}$ at all ages as to avoid rickets or osteomalacia, and that these concentrations can be achieved in all otherwise healthy subjects, even when deprived from sunlight, by a daily vitamin D intake of $10 \mu \mathrm{g}$ (30). These experts did not find sufficient hard data to define higher serum $25(\mathrm{OH}) \mathrm{D}$ or recommend higher vitamin $\mathrm{D}$ intake as to improve bone quality or provide extra-skeletal health benefits.

At the other end of the spectrum, a $25(\mathrm{OH}) \mathrm{D}$ concentration of $75 \mathrm{nmol} / \mathrm{L}(30 \mathrm{ng} / \mathrm{mL})$ or higher is recommended by the Endocrine Society (1). Regarding general health endpoints, the Endocrine Society states that while evidence from RCTs is lacking, numerous epidemiological studies have suggested that a serum $25(\mathrm{OH}) \mathrm{D}$ concentration of $75 \mathrm{nmol} / \mathrm{L}(30 \mathrm{ng} / \mathrm{mL})$ and above may have additional health benefits in reducing the risk of common cancers, autoimmune diseases, type 2 diabetes, cardiovascular disease and infectious diseases $(246,247,248)$. In contrast, the IOM concludes that there is no evidence that a $25(\mathrm{OH}) \mathrm{D}$ threshold greater than $50 \mathrm{nmol} / \mathrm{L}(20 \mathrm{ng} / \mathrm{mL})$ has any additional benefit to health (2), based on the results of RCTs. More recently several other organizations (249), including the European Standing Committee of Medical Doctors (250) and several scientists (3) supported the conclusions of IOM on optimal $25(\mathrm{OH}) \mathrm{D}$ concentrations being $\geq 50 \mathrm{nmol} / \mathrm{L}$. This conclusion is based on RCTs looking at surrogate endpoints such as the level of $25(\mathrm{OH}) \mathrm{D}$ needed to normalize serum $1,25(\mathrm{OH})_{2} \mathrm{D}$ or PTH concentrations, intestinal calcium absorption or bone mineral density. The required intake of vitamin D to achieve such serum 25(OH)D concentrations has been evaluated in numerous studies and an intake in the range of $600-1000 \mathrm{IU}$ of vitamin $\mathrm{D}_{3}$ per day (15-25 $\mu \mathrm{g} /$ day) is adequate for achieving concentration levels of $\geq 50 \mathrm{nmol} / \mathrm{L}$ in more than $97 \%$ of postmenopausal Caucasian or Afro-American women (223). Similar results were found in some European RCTs of young children, children, teenagers, young adults and older adults (251, $252,253,254,255,256)$. Whether a higher dosage is needed for populations with lower baseline 25(OH)D concentrations has not yet been established but evidence from two randomized clinical trials from Lebanon, one in children and another in elderly, suggest that this is the case for countries in the Middle East $(257,258)$. However, calculations of the required vitamin $\mathrm{D}$ to replace the daily metabolic clearance of $25(\mathrm{OH}) \mathrm{D}$ suggest that 600-1000IU/day should be sufficient to maintain serum 25(OH)D concentrations above $50 \mathrm{nmol} / \mathrm{L}$ (3). An intake of $800 \mathrm{IU} /$ day $(20 \mu \mathrm{g} /$ day) has also been proven to be efficient in reducing the risks of fractures and falls in elderly Caucasian women $(3,196,200,218)$. The recent individual participant data meta-analysis in the ODIN study concluded that higher doses are required in order to reach a serum $25(\mathrm{OH}) \mathrm{D}$ concentration of $50 \mathrm{nmol} / \mathrm{L}$ in $97.5 \%$ of the population (259).

Whether higher concentrations of $25(\mathrm{OH}) \mathrm{D}$ would translate into additional skeletal and extra-skeletal effects as suggested by some cross-sectional or observational studies needs to be investigated in additional RCTs. The presently available usually small RCTs using doses of vitamin D above 2000IU/day, however, have not proven additional benefits so far (3). Fortunately, several large scale, long-term RCTs are ongoing (Table 5) and are expected to better define efficacy and optimal dosages of vitamin $\mathrm{D}$ for a variety of other major non-skeletal 
outcomes $(3,260)$. The negative results of the VIDA and VITAL trials suggest that vitamin D is not effective with regard to cardiovascular disease and cancer when baseline $25(\mathrm{OH}) \mathrm{D}$ is high $(242,243)$. Very high dosages of vitamin $\mathrm{D}$ or very high serum $25(\mathrm{OH}) \mathrm{D}$ concentrations may be detrimental. First, vitamin D toxicity can occur (261, 262, 263), characterized by increased urinary calcium excretion, hypercalcemia and ectopic soft tissue calcification, but only exists as a iatrogenic disease when serum 25(OH)D exceeds $250 \mathrm{nmol} / \mathrm{L}$. However, large, intermittent pulse doses of vitamin D (300 000 IU or more) have been found to be associated with increased risks of fractures and falls $(221,264)$. In cross-sectional studies a U-shaped relationship has been found between serum $25(\mathrm{OH}) \mathrm{D}$ concentrations and cancer or mortality whereby not only low but also the highest concentrations were found to pose risks (209). Therefore as has been observed for other fat-soluble vitamins too much as well as too little has to be avoided. Also, vitamin D hypersensitivity due to mutation in the gene encoding for the vitamin D catabolizing enzyme 24-hydroxylase (CYP24A1) should not be neglected $(265,266)$.

A recent review (267) proposes a desirable concentration range of $50-100 \mathrm{nmol} / \mathrm{L}(20-40 \mathrm{ng} / \mathrm{mL})$, provided precise and accurate assays are used. This range allows practitioners to tailor treatment, taking into account season, lifestyle factors and individual vitamin D intake. Most children reach the desirable target concentrations by a daily intake of 400-600 IU (10-15 $\mu \mathrm{g} /$ day), and adults by an intake of $800 \mathrm{IU} /$ day $(20 \mu \mathrm{g} /$ day). This is in line with results from randomized dose-ranging clinical trials $(223,251)$. Additional data is needed to validate the above proposed concentration range and vitamin D doses, especially in children, pregnant women and non-Caucasian populations.

\section{Recommendations on vitamin D intake in Europe and the Middle East}

As stated in the Introduction, the focus of guidelines may be different, varying from public health, as in the IOM guidelines, to individual patients, as in the Endocrine Society guideline. Most national guidelines are made from a public health perspective. A summary of guidelines and recommendations is presented in Table 4. Recently, a more detailed overview of present guidelines for more than 40 countries was published (268).

Most guidelines resemble those of the IOM. The guideline of Central Europe was made by professional societies and resembles the Endocrine Society guideline (269). When recommended intakes are compared with the actual intake, the values only approach each other in the Nordic countries, Norway, Sweden and Finland $(144,147)$.

Recommendations for supplement use have explicitly been made for small children in the Nordic countries, the DACH countries, the UK, Ireland, the Netherlands and Turkey. Specific recommendations for supplement use in other age groups have been made in Finland and the Netherlands. Two guidelines, from Saudi Arabia and United Arabic Emirates, recommended 800-2000IU/day, depending on age category and reproductive status (270, 271). The former was developed with the ESCEO group, and both were exclusively based on expert opinion and review of the evidence from studies conducted in Western populations. The actual use of supplements is high in the Nordic countries and very low in Southern Europe (33) and the Middle East (177).

\section{Strategic options}

The principal goal of a strategy aiming to improve vitamin D status is to prevent vitamin D deficient bone disease, for example rickets in children and fractures in adults and older persons. Strategic options may vary between nihilism and interventions to achieve a serum $25(\mathrm{OH})$ D level above a threshold. The null option to prevent fractures in adults was advocated by the US Preventive Services Task Force (272). This was based on the opinion of the task force that the evidence for an effect of vitamin $\mathrm{D}$ on fracture prevention in older persons was insufficient (273). The IOM has set the required serum 25(OH)D level at $50 \mathrm{nmol} / \mathrm{L}(20 \mathrm{ng} / \mathrm{mL})$ (2). The corresponding required intake (required daily allowance $\mathrm{RDA}$ ) of vitamin $\mathrm{D}$ to achieve $50 \mathrm{nmol} / \mathrm{L}$ was therefore defined at $15 \mu \mathrm{g}$ (600 IU) for $1-70$ year olds and $20 \mu \mathrm{g}$ (800 IU) for older subjects per day, when sun exposure is minimal. The mean vitamin $\mathrm{D}$ intake in most European countries with the exception of the Nordic countries is well below the minimal requirement to achieve the $25(\mathrm{OH}) \mathrm{D}$ threshold of $50 \mathrm{nmol} / \mathrm{L}$ unless there is regular access to sunlight or to vitamin D supplements including cod liver oil (Table 3). Depending on the lifestyle and nutritional habits, the required vitamin D supplementation may vary for different segments of the population and for different countries. For example, in Norway, vitamin D status is adequate in a large part of the population, due to sun exposure on a skin with little pigment, high consumption 

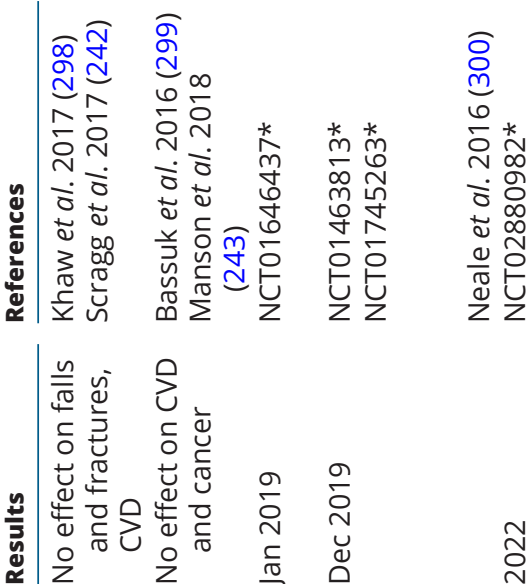

$\begin{array}{ll}0 & 0 \\ \check{0} & 0 \\ & 0 \\ \frac{1}{0} & 0\end{array}$<smiles>O=S=O</smiles>

$\approx$

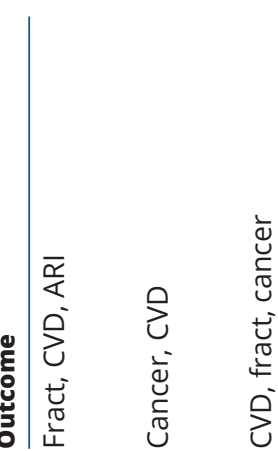

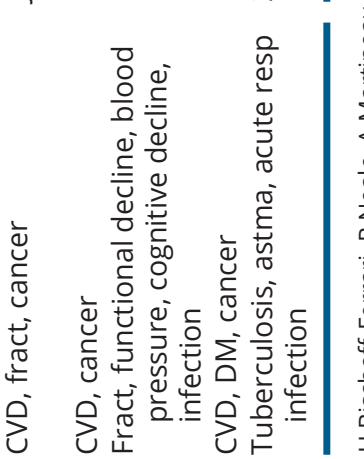

of fish and cod liver oil and adequate dietary calcium intake. In contrast, vitamin D status in Southern Italy may be poor due to low sun exposure on a more pigmented skin, little access to vitamin D-rich food (oily fish or cod liver oil), and a low dietary calcium intake. This means that implementation strategies have to be tailored to the local situation in different countries.

The Endocrine Society has set the required serum $25(\mathrm{OH}) \mathrm{D}$ level at $75 \mathrm{nmol} / \mathrm{L}(30 \mathrm{ng} / \mathrm{mL})$, leading to higher recommendations for vitamin D intake (1) up to 37.5$50 \mu \mathrm{g} /$ day (1500-2000IU/day) in adults (Table 4). The ECTS Working Group does not support this option for the general European population.

\section{Implementation strategies}

Several concepts on implementation exist based either on individual responsibility or on public responsibility. In the first situation this may lead to vitamin D supplementation on an individual basis, based on requirements as stated by national regulatory bodies or professional societies. In the second situation, a more active public health approach, supported by the ECTS, is required involving recommendations for lifestyle including sunshine exposure, healthy nutrition, food fortification and vitamin D supplementation. Implementation can occur through guidelines, professional organizations, special clinics for young children or other risk groups, and publications in the lay press. Providing vitamin D supplements for free is a very effective implementation strategy, as has been shown in Turkey, where children received a free supplement leading to near eradication of rickets within a few years (274).

Vitamin $\mathrm{D}$ can be supplemented as vitamin $\mathrm{D}_{3}$, vitamin $\mathrm{D}_{2}$ and 25-hydroxyvitamin $\mathrm{D}$ (calcifediol). In three clinical trials, using assays that well differentiated $\mathrm{D}_{2}$ and $\mathrm{D}_{3}$ metabolites, vitamin $\mathrm{D}_{3}$ appeared to be somewhat more effective than vitamin $\mathrm{D}_{2}$ in increasing serum 25(OH)D $(275,276,277)$. Most RCTs have used vitamin $\mathrm{D}_{3}$ and currently this is more readily available. Regarding calcifediol, this metabolite appears 2-3 times more effective in increasing serum $25(\mathrm{OH}) \mathrm{D}$ than vitamin $\mathrm{D}_{3}$ (224). Calcifediol might be of value in patients with gastro-intestinal disorders, such as celiac disease, serious liver disease or after gastric bypass surgery, but it is not widely available.

Vitamin D supplements have been dosed daily, weekly, monthly and with larger intervals up to one year. Daily, weekly and monthly doses have been compared in two studies. In one of these, in 48 women serum $25(\mathrm{OH})$ 
D was similar after 2 months in all dosing groups (278). The other study in 338 nursing home residents showed a similar increase of serum $25(\mathrm{OH})$ D with daily or weekly doses, while monthly doses were less effective (279). A yearly dose of $500000 \mathrm{IU}$ was given in an Australian clinical trial to prevent hip fractures, but the fall and fracture incidence in the vitamin D group were higher than in the placebo group (221). A yearly intramuscular dose of vitamin D (300 000 IU) given in a UK study also was not effective (264).

Absorption with a meal containing some fat appears to improve vitamin D absorption (280). While loading doses have been recommended in case of deficiency by some experts, there is no evidence of the clinical value of such loading doses.

\section{Public health options}

The use of cod liver oil was very common in Western Europe to prevent rickets, and still is very widespread in the Nordic countries. A recent meta-analysis demonstrated that at a dose as low as $400 \mathrm{IU} /$ day $(10 \mu \mathrm{g} /$ day $)$ vitamin D prevents the occurrence of rickets (281). The advice to use vitamin D drops $10 \mu \mathrm{g} /$ day (400 IU/day) in infants and children below 4 years was and still is common practice in the Netherlands and several other Western European countries in special children consultation clinics visited by a great majority of young children. Rickets was an important public health problem in Turkey, leading to the institution of a population-based preventive program in 2005 (274). The free distribution of vitamin D drops to all newborn infants visiting primary care facilities in Turkey has decreased the prevalence of rickets from $6 \%$ in 1998 to $0.1 \%$ in 2008 in children under 3 years of age $(274,282)$. A similar experience has been reported from Finland, Canada and New Zealand (47, 283, 284).

The IOM increased its RDAs for vitamin D 7 years ago, ranging from 10 to $20 \mu \mathrm{g} /$ day, considerably lower than those of the Endocrine Society $(1,14)$. There were also recent global consensus recommendations on prevention and management of nutritional rickets (285): supplementation with $10 \mu \mathrm{g} /$ day (400 IU/day) is adequate to prevent rickets and is recommended for all infants from birth to 12 months of age, independent of their mode of feeding. Beyond 12 months of age, all children and adults need to meet their nutritional requirement for vitamin $\mathrm{D}$ through diet and/or supplementation, which is at least $15 \mu \mathrm{g} /$ day (600 IU/day), similar to the recommendation of the IOM. The global consensus of rickets also recommends an intake of $15 \mu \mathrm{g} /$ day for pregnant women (285). Based on a Cochrane meta-analysis, the WHO recommends against routine vitamin $\mathrm{D}$ supplementation in pregnancy (286). A more recent update of the Cochrane analysis was more positive about potential benefits of vitamin D supplementation in pregnancy, but the authors concluded that evidence is not sufficient yet for a general supplementation advice in pregnancy (287). Recommendations from a WHO-sponsored symposium during the 2015 Vitamin D Workshop (288) endorsed a correction of widespread vitamin D deficiency of pregnant women in line with the recommendations for all adult females (10-15 $\mu \mathrm{g} /$ day), as part of antenatal care in general. Special risk groups such as pregnant women in the Middle East and pregnant non-Western immigrant women in Europe probably require a vitamin D supplement (65, 85). Some randomized vitamin $D$ trials revealed that the majority of mothers failed to achieve the required serum 25(OH)D level even with doses by far exceeding current recommendations (92). However, it is questionable whether vitamin D doses of 15-20 $\mathrm{gg} /$ day (600-800 IU/day) actually are too low, or rather that compliance to these doses may not have been adequate. In a recent dose-finding trial, doses of 600-800 IU/day were sufficient to achieve a $25(\mathrm{OH}) \mathrm{D}$ concentration of more than $50 \mathrm{nmol} / \mathrm{L}$ in $97 \%$ of postmenopausal women (223) similar to findings in an earlier study in Dutch institutionalized elderly (251).

\section{Food fortification with vitamin D}

As mentioned above, the dietary intakes of children and adults in European countries, as well as beyond Europe, have been comprehensively reviewed recently $(33,138$, 289). In brief, intakes of vitamin D in national surveys throughout Europe (e.g. UK, Ireland, Denmark and France) are typically below $5 \mu \mathrm{g} /$ day, except for the Nordic countries, and vary according to contribution from nutritional supplements, country-specific fortification practices, sex and age; with the nutritional supplements being the main source of variation. Overall, it is clear that the current dietary supply of vitamin D makes it unfeasible for most children and adults in Europe to meet the IOM's EAR of $10 \mu \mathrm{g} / \mathrm{day}$ (400 IU/day), let alone the RDA of $15 \mu \mathrm{g} /$ day (600 IU/day), which were established on the assumption of minimal or absent UVB-induced dermal supply. It has been emphasized that there is only a limited number of public health strategies available to correct low dietary vitamin D intake $(289,290)$. A brief overview will be provided here: 
1. Improving intake of naturally occurring vitamin D-rich foods. This is the least likely strategy to increase dietary vitamin $\mathrm{D}$ intake because there are very few food sources that are rich in vitamin $\mathrm{D}$, such as oily fish, with limited availability. Furthermore, most of these are not frequently consumed by many in the population (290).

2. Vitamin D supplementation. Supplementation with vitamin $\mathrm{D}$ has been shown to significantly improve vitamin D intake across a variety of age, race, ethnic and gender groups as well as improving vitamin $\mathrm{D}$ status per se. However, the population intake of vitamin D from supplements is quite low (291). This is mainly due to the relatively low vitamin $\mathrm{D}$ content of most supplements compared to the requirement as discussed earlier. While not highly effective at a population level due to the low percentage of compliance in the general population for most European countries, vitamin D supplementation may be appropriate in high-risk groups such as infants and young children, pregnant women and older persons (250). Actually, vitamin D supplements are systematically recommended for young children from 0 to 3 years in several countries and also for all institutionalized elderly subjects (249).

3. Vitamin $D$ fortification (mandatory or voluntarily) of food. While supplements are an effective method for individuals to increase their intake, food fortification represents the best opportunity to increase the vitamin D supply to the population $(138,289,292)$. Fortification of foods with vitamin D in the United States and Canada has an important effect on the mean daily intake of vitamin $\mathrm{D}$ by the average adult, but it does not yet reach the required levels of vitamin D intake (293). This may relate to the level of fortification, types and choice of food vehicles and the issue of mandatory or optional/voluntary fortification. It was recently demonstrated that the 95th percentile of intake of vitamin D from voluntary fortified foods in Europe is low (291). Finland has focused on improving vitamin D status in the whole population by extensive fortification. In April 2010, The National Nutrition Council launched a new recommendation that the earlier fortification levels should be doubled to $1.0 \mu \mathrm{g} / 100 \mathrm{~g}(40 \mathrm{IU} / 100 \mathrm{~g})$ for all fluid milk products and that $20 \mu \mathrm{g} / 100 \mathrm{~g}(800 \mathrm{IU} / 100 \mathrm{~g})$ should be used for spreadable fats. These recommendations were based on simulations of the effect of fortification. Especially the dairy industry responded immediately and almost all fluid milk products were fortified, with the exception of ecological products. This fortification has had a positive impact on the vitamin D intake and status in adults, whose mean vitamin $\mathrm{D}$ intake now is about $10 \mu \mathrm{g}$, where close to $40-50 \%$ comes from fortified milk products (147). The vitamin D status has also improved as demonstrated recently when a comparison of standardized serum 25(OH) $\mathrm{D}$ data from two nationally representative surveys of Finnish adults 11 years apart showed that less than $6 \%$ had a $25(\mathrm{OH}) \mathrm{D}$ concentration lower than $50 \mathrm{nmol} / \mathrm{L}$ in the autumn/early winter months in 2011 compared to the situation in 2000 when about $50 \%$ had concentrations lower than $50 \mathrm{nmol} / \mathrm{L}$ (47). Also of note, the prevalence of severe vitamin $\mathrm{D}$ deficiency $(<30 \mathrm{nmol} / \mathrm{L})$ decreased from $13 \%$ to $0.6 \%$ over the 11 year period (47).

The ECTS Working Group acknowledges the valuable contribution of fortified milk to vitamin D intakes, particularly in children, and the continued need for fortification of milk and other dairy products. However, fortification, including bio-fortification, of a wider range of foods offers more possibilities. Well-designed sustainable fortification strategies, which use a range of foods to accommodate diversity, have the potential to increase vitamin D intakes across the population distribution and minimize the prevalence of a low serum $25(\mathrm{OH}) \mathrm{D}$ concentration $(294,295)$. To provide evidence, we need to model European food and vitamin D intake data to ascertain which food vehicles and what level of vitamin $\mathrm{D}$ addition will ensure an effective but safe rise in serum 25(OH)D concentration in all segments of the European population. The benefits and limitations of bio-fortification of various foods are investigated in the EU Framework 7 ODIN project. This includes plant and animal-based food via UVB irradiation of yeast and mushrooms (296), and addition of the most effective forms of vitamin $\mathrm{D}$ (vitamin $\mathrm{D}_{3}$ or calcifediol in some cases) to the feeds of the animals with ultimate inclusion in the tissue for use as foods. Data from the project suggests that a combination of traditional fortification of dairy foods together with the newer approach of bio-fortification of foods with vitamin D can allow for an mean intake within the population of $10 \mu \mathrm{g} /$ day conforming to the EAR (2) as published by the IOM.

In Middle East countries food fortification is sporadic and the use of supplements is low (177). Furthermore, dairy products are only consumed by a minority of the population. Fortification of wheat flour may have potential to alleviate vitamin $\mathrm{D}$ deficiency in countries 
such as India and Jordan, where pasteurized milk is not widely consumed (297). The Gulf Countries Council mandates a wheat flour standard (GS194) that includes vitamin D fortification of flour, and several countries have initiated it. These include Jordan, Palestine and Saudi Arabia that initiated flour fortification with vitamin $\mathrm{D}$ at $13.8 \mu \mathrm{g}$ (550 IU) per kg of flour, a very cost-effective public health intervention to prevent rickets, estimated to incur a cost of $0.04-0.05$ US\$ per metric ton of flour (Personal communication Quentin Johnson, Food Fortification Initiative, www.ffinetwork.org and Ayoub Al Jawaldeh WHO Eastern Mediterranean Region). The United States Agency for International Development adds $13.8 \mu \mathrm{g}$ (550IU) of vitamin $\mathrm{D} / \mathrm{kg}$ of vegetable oil standard, $0.4-0.6 \mu \mathrm{g}$ (16-23 IU) per $\mathrm{g}$ of oil for their food aid programs. Such initiatives will help countries like Yemen, Iraq and now Syrian refugees in Lebanon, Jordan, Iraq and Turkey. World Food Program standards include vitamin D in both cereal flours and vegetable oil for their emergency programs, an important point in the Middle East refugee context. While these initiatives will undoubtedly help boost serum 25(OH)D concentrations in these regions, their impact on attaining serum $25(\mathrm{OH})$ $\mathrm{D}$ target concentrations, if higher than very conservative ones, is less clear. In addition, vegetable oil and milk standards may include vitamin $\mathrm{A}$ and $\mathrm{D}$, but these are mostly voluntary or by covenant at the moment. More on micronutrient fortification of foods in developing countries can be found on http://www.gainhealth. org/programs/initiatives/\#global-tracking.

\section{Recommendations}

The ECTS Working Group recommends the following:

- A reliable estimation of vitamin D status, such as performed in the ODIN project, should be performed in all European countries and the Middle East (28). This requires utilization of protocol to conduct retrospective standardization of the available serum $25(\mathrm{OH}) \mathrm{D}$ data as well as a greater effort to standardize assays for accurate measurement of $25(\mathrm{OH}) \mathrm{D}$ into the future. All publications and reports on vitamin $\mathrm{D}$ status should include such standardized data.

- Fortification of foods is the preferred strategy to increase vitamin $\mathbf{D}$ intake and status over all segments of the population, provided that adequate quality assurance monitoring is performed. Milk, yogurt and other milk products are to be fortified with around $10 \mu \mathrm{g} / \mathrm{L}(400 \mathrm{IU} / \mathrm{L})$. Other options such as fortification of flour and oil with vitamin D as well as bio-fortification of animal-derived food products, such as eggs, red meats and cultured fish, should be considered carefully as additional means of increasing vitamin D intake in the population.

- Vitamin D supplements are recommended for special risk groups in order to increase the serum 25(OH)D concentration above $50 \mathrm{nmol} / \mathrm{L}$ in all countries of Europe and the Middle East.

- A vitamin $D$ supplement of $10 \mu \mathrm{\mu} / \mathrm{day}$ (400IU/day) is advised for all children of 0-1 year and preferably 0-3 year to eradicate rickets.

- A vitamin D supplement of 10-15 $1 \mathrm{~g} / \mathrm{day}$ (400$600 \mathrm{IU} / \mathrm{day}$ ) is advised for all pregnant women.

- A vitamin D supplement of 10-20 $\mathrm{\mu g} / \mathrm{day}$ (400-800 IU/day) is advised- to all older institutionalized subjects and should be considered for all older persons above 70 year.

- A vitamin D supplement of $10 \mu \mathrm{g} /$ day (400 IU/day) should be considered for non-Western immigrants and refugees.

\section{Research agenda}

- Effects of food fortification (milk, oil, flour/bread, juice, bio-fortified foods) have to be studied per fortified food item in different countries with regard to different risk groups in the population such as young children, pregnant women, older persons and non-Western immigrants and compared with the effects of vitamin D supplementation.

- Further study is needed on vitamin D requirement in the Middle East $(257,258)$ and on measures to prevent vitamin $\mathrm{D}$ deficiency.

- The impact of individual participant data (IPD) metaregression analysis on the required vitamin $\mathrm{D}$ intake compared to standard meta-regression has to be studied, as the latter suggests that the requirement may be higher (259). The IPD approach could be applied to other population subgroups, such as pregnant women and ethnic groups.

- Regular monitoring of vitamin D intake (using comprehensive vitamin D food composition data) and vitamin D status by standardized $25(\mathrm{OH}) \mathrm{D}$ assays should be organized in all European and Middle East countries and should guide future intervention strategies.

- The occurrence of rickets should be monitored in all European and Middle East countries. 
- When the results of ongoing large randomized vitamin D trials (Table 5) become available, the optimal serum $25(\mathrm{OH}) \mathrm{D}$ concentration and the corresponding vitamin D intake should be adjusted.

- Genetic studies are recommended to investigate the individual vulnerability for vitamin D deficiency. Mendelian randomization studies can elucidate the long-term impact of vitamin D deficiency on cancer and autoimmune disease outcomes, as to guide clinical decision-making in case RCTs are not available and cannot be performed for whatever reason.

\section{Conclusion}

In order to compare vitamin $\mathrm{D}$ status between different countries and to get a reliable estimate of the prevalence of vitamin D deficiency, standardized 25(OH)D assays should be used in population-based surveys. This should include all ongoing studies and whenever possible, also representative samples of older major published surveys and trials. The prevalence of a low serum 25(OH)D concentration $(<50 \mathrm{nmol} / \mathrm{L})$ is high, that is more than $50 \%$ during winter, in many European and Middle East countries. Even more worrying is the presence of severe vitamin D deficiency (below 25/30 nmol/L) in specific risk groups. The spectrum ranges from adequate vitamin D status in the Nordic countries to severe deficiency in the Middle East. Vitamin D status usually is poor in non-Western immigrants. According to current evidence, the desirable serum $25(\mathrm{OH}) \mathrm{D}$ concentration is set at $50 \mathrm{nmol} / \mathrm{L}$ or higher. While most experts agree on this concentration, it is uncertain whether higher concentrations provide additional benefit. When the results of ongoing randomized clinical trials are available, the required serum $25(\mathrm{OH}) \mathrm{D}$ concentration may have to be modified, depending on the outcome. It will require a tremendous effort to improve vitamin D status in Europe and the Middle East and reduce the percentage of the population with a serum $25(\mathrm{OH}) \mathrm{D}$ concentration below $50 \mathrm{nmol} / \mathrm{L}$. This may translate into targeted approaches such as prudent sun exposure, adequate nutrition, food fortification policy and vitamin D supplementation for high-risk groups. Elimination of nutritional rickets should receive the highest priority. As there is near universal agreement that serum 25(OH)D concentrations should exceed $25 / 30 \mathrm{nmol} / \mathrm{L}$; at whatever age, strategies to eliminate this deficiency, particularly in children, pregnant women, older persons and immigrants, should receive the highest priority by public health authorities and health care providers.

\section{Declaration of interest}

Paul Lips: He received lecture fee from Abiogen. He chaired the vitamin D Workshop in 2015. Kevin D Cashman: He was a member of the UK SACN vitamin D working group. Heike Annette Bischoff-Ferrari: During the last 3 years HABF received investigator-initiated grant support from DSM Nutritional Products and WILD, received speaker fees from Pfizer, Roche Diagnostics, Meda, Sandoz and Sanofi. Maria Luisa Bianchi: She received consultancy honoraria from Alexion Pharmaceuticals and Kyowa Kirin. Roger Bouillon: He received lecture fees (over the last 2 years) from Abiogen, l'Oreal and FAES (Spain) and Fresenius, and is co-owner of an university patent on vitamin D analogs, licensed to Hybrigenix (France); he is member of the organizing committee of the Vitamin D Workshop. The other authors have nothing to disclose.

\section{Funding}

This research did not receive any specific grant from any funding agency in the public, commercial or not-for-profit sector.

\section{References}

1 Holick MF, Binkley NC, Bischoff-Ferrari HA, Gordon CM, Hanley DA, Heaney RP, Murad MH, Weaver CM \& Endocrine Society. Evaluation, treatment, and prevention of vitamin D deficiency: an Endocrine Society clinical practice guideline. Journal of Clinical Endocrinology and Metabolism 201196 1911-1930. (https://doi.org/10.1210/jc.2011-0385)

2 Institute of Medicine. Dietary Reference Intakes for Calcium and Vitamin D. Washington DC: The National Academies Press, 2011.

3 Bouillon R, van Schoor NM, Gielen E, Boonen S, Mathieu C, Vanderschueren D \& Lips P. Optimal vitamin D status: a critical analysis on the basis of evidence-based medicine. Journal of Clinical Endocrinology and Metabolism 201398 E1283-E1304. (https://doi. org/10.1210/jc.2013-1195)

4 Seamans KM \& Cashman KD. Existing and potentially novel functional markers of vitamin D status: a systematic review. American Journal of Clinical Nutrition 200989 1997S-2008S. (https://doi. org/10.3945/ajcn.2009.27230D)

5 Carter GD, Jones JC, Shannon J, Williams EL, Jones G, Kaufmann M \& Sempos C. 25-Hydroxyvitamin D assays: potential interference from other circulating vitamin D metabolites. Journal of Steroid Biochemistry and Molecular Biology 2016164 134-138. (https://doi. org/10.1016/j.jsbmb.2015.12.018)

6 Jongen MJ, van der Vijgh WJ, Willems HJ, Netelenbos JC \& Lips P. Simultaneous determination of 25-hydroxyvitamin D, 24,25-dihydroxyvitamin D, and 1,25-dihydroxyvitamin D in plasma or serum. Clinical Chemistry 198127 1757-1760.

7 Cashman KD, Hayes A, Galvin K, Merkel J, Jones G, Kaufmann M, Hoofnagle AN, Carter GD, Durazo-Arvizu RA \& Sempos CT. Significance of serum 24,25-dihydroxyvitamin D in the assessment of vitamin D status: a double-edged sword? Clinical Chemistry 2015 61 636-645. (https://doi.org/10.1373/clinchem.2014.234955)

8 Kaufmann M, Gallagher JC, Peacock M, Schlingmann KP, Konrad M, DeLuca HF, Sigueiro R, Lopez B, Mourino A, Maestro $\mathrm{M}$ et al. Clinical utility of simultaneous quantitation of 25-hydroxyvitamin D and 24,25-dihydroxyvitamin D by LC-MS/ MS involving derivatization with DMEQ-TAD. Journal of Clinical Endocrinology and Metabolism 201499 2567-2574. (https://doi. org/10.1210/jc.2013-4388) 
9 Molin A, Baudoin R, Kaufmann M, Souberbielle JC, Ryckewaert A, Vantyghem MC, Eckart P, Bacchetta J, Deschenes G, KeslerRoussey G et al. CYP24A1 mutations in a cohort of hypercalcemic patients: evidence for a recessive trait. Journal of Clinical Endocrinology and Metabolism 2015100 E1343-E1352. (https://doi. org/10.1210/jc.2014-4387)

10 Lips P. Relative value of 25(OH)D and 1,25(OH)2D measurements. Journal of Bone and Mineral Research 200722 1668-1671. (https://doi. org/10.1359/jbmr.070716)

11 Abreu MT, Kantorovich V, Vasiliauskas EA, Gruntmanis U, Matuk R, Daigle K, Chen S, Zehnder D, Lin YC, Yang H et al. Measurement of vitamin D levels in inflammatory bowel disease patients reveals a subset of Crohn's disease patients with elevated 1,25-dihydroxyvitamin D and low bone mineral density. Gut 2004 53 1129-1136. (https://doi.org/10.1136/gut.2003.036657)

12 Makin HLJ, Jones G, Kaufmann M \& Calverley MJ. Analysis of vitamin D, their metabolites and analogs. In Steroid Analysis, 2nd ed., Chapter 11, pp 967-1096. Eds HLJ Makin \& DB Gower. Springer Science and Business Media, Berlin 2010.

13 Hollis BW \& Napoli JL. Improved radioimmunoassay for vitamin D and its use in assessing vitamin D status. Clinical Chemistry 198531 1815-1819.

14 Ross AC, Manson JE, Abrams SA, Aloia JF, Brannon PM, Clinton SK, Durazo-Arvizu RA, Gallagher JC, Gallo RL, Jones G et al. The 2011 report on dietary reference intakes for calcium and vitamin $\mathrm{D}$ from the Institute of Medicine: what clinicians need to know. Journal of Clinical Endocrinology and Metabolism 201196 53-58. (https://doi. org/10.1210/jc.2010-2704)

15 De la Hunty A, Wallace AM, Gibson S, Viljakainen H, LambergAllardt C \& Ashwell M. UK Food Standards Agency Workshop Consensus Report: the choice of method for measuring 25-hydroxyvitamin D to estimate vitamin D status for the UK National Diet and Nutrition Survey. British Journal of Nutrition 2010 104 612-619. (https://doi.org/10.1017/S000711451000214X)

16 Bikle D, Bouillon R, Thadhani R \& Schoenmakers I. Vitamin D metabolites in captivity? Should we measure free or total $25(\mathrm{OH})$ $\mathrm{D}$ to assess vitamin D status? Journal of Steroid Biochemistry and Molecular Biology 2017173 105-116. (https://doi.org/10.1016/j. jsbmb2017.01.007)

17 Carter GD, Berry JL, Gunter E, Jones G, Jones JC, Makin HLJ, Sufi S \& Wheeler MJ. Proficiency testing of 25-hydroxyvitamin D (25-OHD) assays. Journal of Steroid Biochemistry and Molecular Biology 2010121 176-179. (https://doi.org/10.1016/j.jsbmb.2010.03.033)

18 Carter GD \& Jones JC. Use of a common standard improves the performance of liquid chromatography-tandem mass spectrometry methods for serum 25 -hydroxyvitamin-D. Annals of Clinical Biochemistry 200946 79-81. (https://doi.org/10.1258/ acb.2008.008135)

19 Barake M, Daher RT, Salti I, Cortas NK, Al-Shaar L, Habib RH \& Fuleihan Gel-H. 25-Hydroxyvitamin D assay variations and impact on clinical decision making. Journal of Clinical Endocrinology and Metabolism 201297 835-843. (https://doi. org/10.1210/jc.2011-2584)

20 Carter GD, Berry J, Durazo-Arvizu R, Gunter E, Jones G, Jones J, Makin HLJ, Pattni P, Sempos CT, Twomey P et al. Hydroxyvitamin D assays: an historical perspective from DEQAS. Journal of Steroid Biochemistry and Molecular Biology 2018177 30-35. (https://doi. org/10.1016/j.jsbmb.2017.07.018)

21 Binkley N, Sempos CT \& Vitamin D Standardization Program (VDSP). Standardizing vitamin D assays: the way forward. Journal of Bone and Mineral Research 201429 1709-1714. (https://doi.org/10.1002/ jbmr.2252)

22 Binkley N, Krueger D, Cowgill CS, Plum L, Lake E, Hansen KE, DeLuca HF \& Drezner MK. Assay variation confounds the diagnosis of hypovitaminosis D: a call for standardization. Journal of Clinical
Endocrinology and Metabolism 200489 3152-3157. (https://doi. org/10.1210/jc.2003-031979)

23 Lips P, Chapuy MC, Dawson-Hughes B, Pols HA \& Holick MF. An international comparison of serum 25-hydroxyvitamin D measurements. Osteoporosis International 19999 394-397. (https:// doi.org/10.1007/s001980050162)

24 Sempos CT, Vesper HW, Phinney KW, Thienpont LM, Coates PM \& Vitamin D Standardization Program (VDSP). Vitamin D status as an international issue: national surveys and the problem of standardization. Scandinavian Journal of Clinical and Laboratory Investigation. Supplementum 2012243 32-40. (https://doi.org/10.3109 /00365513.2012.681935)

25 Prentice A. Vitamin D deficiency: a global perspective. Nutrition Reviews 200866 S153-S164. (https://doi.org/10.1111/j.17534887.2008.00100.x)

26 Binkley N \& Carter GD. Toward clarity in clinical vitamin D status assessment: $25(\mathrm{OH}) \mathrm{D}$ assay standardization. Endocrinology and Metabolism Clinics of North America 201746 885-899. (https://doi. org/10.1016/j.ecl.2017.07.012)

27 Sempos CT, Durazo-Arvizu RA, Dawson-Hughes B, Yetley EA, Looker AC, Schleicher RL, Cao G, Burt V, Kramer H, Bailey RL et al. Is there a reverse $\mathrm{J}$-shaped association between 25 -hydroxyvitamin $\mathrm{D}$ and all-cause mortality? Results from the U.S. nationally representative NHANES. Journal of Clinical Endocrinology and Metabolism 201398 3001-3009. (https://doi.org/10.1210/jc.20131333)

28 Cashman KD, Dowling KG, Skrabakova Z, Gonzalez-Gross M, Valtuena J, De Henauw S, Moreno L, Damsgaard CT, Michaelsen KF, Molgaard C et al. Vitamin D deficiency in Europe: pandemic? American Journal of Clinical Nutrition 2016103 1033-1044. (https:// doi.org/10.3945/ajcn.115.120873)

29 European Food Safety Authority EEFS. Scientific opinion on dietary reference values for vitamin D. EFSA Journal $2016 \mathbf{1 4} 4547$.

30 Scientific Advisory Committee on Nutrition. Draft SACN vitamin D and health report (Internet). Report Pdf, 2015.

31 van der Wielen RP, Lowik MR, van den Berg H, de Groot LC, Haller J, Moreiras O \& van Staveren WA. Serum vitamin D concentrations among elderly people in Europe. Lancet 1995346 207-210. (https:// doi.org/10.1016/S0140-6736(95)91266-5)

32 McKenna MJ. Differences in vitamin D status between countries in young adults and the elderly. American Journal of Medicine 199293 69-77. (https://doi.org/10.1016/0002-9343(92)90682-2)

33 Spiro A \& Buttriss JL. Vitamin D: an overview of vitamin D status and intake in Europe. Nutrition Bulletin 201439 322-350. (https:// doi.org/10.1111/nbu.12108)

34 Wahl DA, Cooper C, Ebeling PR, Eggersdorfer M, Hilger J, Hoffman K, Josse R, Kanis JA, Mithal A, Pierroz DD et al. A global representation of vitamin D status in healthy populations. Archives of Osteoporosis 20127 155-172. (https://doi.org/10.1007/s11657-012-0093-0)

35 Hilger J, Friedel A, Herr R, Rausch T, Roos F, Wahl DA, Pierroz DD, Weber P \& Hoffmann K. A systematic review of vitamin D status in populations worldwide. British Journal of Nutrition $201411123-45$. (https://doi.org/10.1017/S0007114513001840)

36 Cashman KD, Dowling KG, Skrabakova Z, Kiely M, LambergAllardt C, Durazo-Arvizu RA, Sempos CT, Koskinen S, Lundqvist A, Sundvall $\mathrm{J}$ et al. Standardizing serum 25-hydroxyvitamin D data from four Nordic population samples using the Vitamin D Standardization Program protocols: shedding new light on vitamin D status in Nordic individuals. Scandinavian Journal of Clinical and Laboratory Investigation 201575 549-561. (https://doi.org/10.3109/00365513.2015.1057898)

37 Buchebner D, McGuigan F, Gerdhem P, Malm J, Ridderstrale M \& Akesson K. Vitamin D insufficiency over 5 years is associated with increased fracture risk-an observational cohort study of elderly women. Osteoporosis International 201425 2767-2775. (https://doi. org/10.1007/s00198-014-2823-1) 
38 Melhus H, Snellman G, Gedeborg R, Byberg L, Berglund L, Mallmin H, Hellman P, Blomhoff R, Hagstrom E, Arnlov J et al. Plasma 25-hydroxyvitamin D levels and fracture risk in a community-based cohort of elderly men in Sweden. Journal of Clinical Endocrinology and Metabolism 201095 2637-2645. (https:// doi.org/10.1210/jc.2009-2699)

39 Brembeck P, Winkvist A \& Olausson H. Determinants of vitamin D status in pregnant fair-skinned women in Sweden. British Journal of Nutrition 2013110 856-864. (https://doi.org/10.1017/ S0007114512005855)

40 Eriksson S \& Strandvik B. Vitamin D status in healthy children in Sweden still satisfactory. Changed supplementation and new knowledge motivation for further studies. Läkartidningen 2016107 2474-2477.

41 Andersen R, Molgaard C, Skovgaard LT, Brot C, Cashman KD, Chabros E, Charzewska J, Flynn A, Jakobsen J, Karkkainen M et al. Teenage girls and elderly women living in northern Europe have low winter vitamin D status. European Journal of Clinical Nutrition 200559 533-541. (https://doi.org/10.1038/sj.ejcn.1602108)

42 Holvik K, Meyer HE, Haug E \& Brunvand L. Prevalence and predictors of vitamin D deficiency in five immigrant groups living in Oslo, Norway: the Oslo Immigrant Health Study. European Journal of Clinical Nutrition 200559 57-63. (https://doi.org/10.1038/ sj.ejcn.1602033)

43 Andersen R, Molgaard C, Skovgaard LT, Brot C, Cashman KD, Jakobsen J, Lamberg-Allardt C \& Ovesen L. Pakistani immigrant children and adults in Denmark have severely low vitamin D status. European Journal of Clinical Nutrition 200862 625-634. (https://doi. org/10.1038/sj.ejcn.1602753)

44 Holvik K, Ahmed LA, Forsmo S, Gjesdal CG, Grimnes G, Samuelsen SO, Schei B, Blomhoff R, Tell GS \& Meyer HE. Low serum levels of 25-hydroxyvitamin D predict hip fracture in the elderly: a NOREPOS study. Journal of Clinical Endocrinology and Metabolism 2013 98 3341-3350. (https://doi.org/10.1210/jc.2013-1468)

45 Holvik K, Brunvand L, Brustad M \& Meyer HE. Vitamin D Status in the Norwegian Population. Oslo: The Norwegian Academy of Science and Letters, 2008

46 Steingrimsdottir L, Gunnarsson O, Indridason OS, Franzson L \& Sigurdsson G. Relationship between serum parathyroid hormone levels, vitamin D sufficiency, and calcium intake. JAMA 2005294 2336-2341. (https://doi.org/10.1001/jama.294.18.2336)

47 Jaaskelainen T, Itkonen ST, Lundqvist A, Erkkola M, Koskela T, Lakkala K, Dowling KG, Hull GL, Kroger H, Karppinen J et al. The positive impact of general vitamin $\mathrm{D}$ food fortification policy on vitamin D status in a representative adult Finnish population: evidence from an 11-y follow-up based on standardized 25-hydroxyvitamin D data. American Journal of Clinical Nutrition 2017 105 1512-1520. (https://doi.org/10.3945/ajcn.116.151415)

48 Carson EL, Pourshahidi LK, Hill TR, Cashman KD, Strain JJ, Boreham CA \& Mulhern MS. Vitamin D, muscle function, and cardiorespiratory fitness in adolescents from the Young Hearts Study. Journal of Clinical Endocrinology and Metabolism 2015100 4621-4628. (https://doi.org/10.1210/jc.2015-2956)

49 van Schoor NM, Knol DL, Deeg DJ, Peters FP, Heijboer AC \& Lips P. Longitudinal changes and seasonal variations in serum 25-hydroxyvitamin D levels in different age groups: results of the Longitudinal Aging Study Amsterdam. Osteoporosis International 2014 25 1483-1491. (https://doi.org/10.1007/s00198-014-2651-3)

50 Bouillon RA, Auwerx JH, Lissens WD \& Pelemans WK. Vitamin D status in the elderly: seasonal substrate deficiency causes 1,25-dihydroxycholecalciferol deficiency. American Journal of Clinical Nutrition 198745 755-763. (https://doi.org/10.1093/ajcn/45.4.755)

51 Hoge A, Donneau AF, Streel S, Kolh P, Chapelle JP, Albert A, Cavalier E \& Guillaume M. Vitamin D deficiency is common among adults in Wallonia (Belgium, 51 degrees 30' North): findings from the Nutrition, Environment and Cardio-Vascular Health study.
Nutrition Research 201535 716-725. (https://doi.org/10.1016/j. nutres.2015.06.005)

52 Chapuy MC, Preziosi P, Maamer M, Arnaud S, Galan P, Hercberg S \& Meunier PJ. Prevalence of vitamin D insufficiency in an adult normal population. Osteoporosis International 19977 439-443. (https://doi. org/10.1007/s001980050030)

53 Chapuy MC, Schott AM, Garnero P, Hans D, Delmas PD \& Meunier PJ. Healthy elderly French women living at home have secondary hyperparathyroidism and high bone turnover in winter. EPIDOS Study Group. Journal of Clinical Endocrinology and Metabolism 199681 1129-1133. (https://doi.org/10.1210/jcem.81.3.8772587)

54 Souberbielle JC, Massart C, Brailly-Tabard S, Cavalier E \& Chanson P. Prevalence and determinants of vitamin D deficiency in healthy French adults: the VARIETE study. Endocrine 201653 543-550. (https://doi.org/10.1007/s12020-016-0960-3)

55 Burnand B, Sloutskis D, Gianoli F, Cornuz J, Rickenbach M, Paccaud F \& Burckhardt P. Serum 25-hydroxyvitamin D: distribution and determinants in the Swiss population. American Journal of Clinical Nutrition 199256 537-542. (https://doi.org/10.1093/ ajcn/56.3.537)

56 Cashman KD, Muldowney S, McNulty B, Nugent A, FitzGerald AP, Kiely M, Walton J, Gibney MJ \& Flynn A. Vitamin D status of Irish adults: findings from the National Adult Nutrition Survey. British Journal of Nutrition 2013109 1248-1256. (https://doi.org/10.1017/ S0007114512003212)

57 Theiler R, Stahelin HB, Tyndall A, Binder K, Somorjai G \& Bischoff HA. Calcidiol, calcitriol and parathyroid hormone serum concentrations in institutionalized and ambulatory elderly in Switzerland. International Journal for Vitamin and Nutrition Research 199969 96-105. (https://doi.org/10.1024/0300-9831.69.2.96)

58 Krieg MA, Cornuz J, Jacquet AF, Thiebaud D \& Burckhardt P. Influence of anthropometric parameters and biochemical markers of bone metabolism on quantitative ultrasound of bone in the institutionalized elderly. Osteoporosis International 19988 115-120. (https://doi.org/10.1007/BF02672506)

59 Bischoff-Ferrari HA, Can U, Staehelin HB, Platz A, Henschkowski J, Michel BA, Dawson-Hughes B \& Theiler R. Severe vitamin D deficiency in Swiss hip fracture patients. Bone 200842 597-602. (https://doi.org/10.1016/j.bone.2007.10.026)

60 Bischof MG, Heinze G \& Vierhapper H. Vitamin D status and its relation to age and body mass index. Hormone Research $2006 \mathbf{6 6}$ 211-215. (https://doi.org/10.1159/000094932)

61 Amrein K, Zajic P, Schnedl C, Waltensdorfer A, Fruhwald S, Holl A, Purkart T, Wunsch G, Valentin T, Grisold A et al. Vitamin D status and its association with season, hospital and sepsis mortality in critical illness. Critical Care 201418 R47. (https://doi.org/10.1186/cc13790)

62 Kudlacek S, Schneider B, Peterlik M, Leb G, Klaushofer K, Weber K, Woloszczuk W, Willvonseder R \& Austrian Study Group on Normative Values of Bone. Assessment of vitamin D and calcium status in healthy adult Austrians. European Journal of Clinical Investigation 200333 323-331. (https://doi.org/10.1046/j.13652362.2003.01127.x)

63 Goldrace M, Hall N \& Yeates DG. Hospitalisation for children with rickets in England: a historical perspective. Lancet 2014383 597-598. (https://doi.org/10.1016/S0140-6736(14)60211-7)

64 van der Meer IM, Boeke AJP, Lips P, Grootjans-Geerts I, Wuister JD, Deville WLJM, Wielders JPM, Bouter LM \& Middelkoop BJC. Fatty fish and supplements are the greatest modifiable contributors to the serum 25-hydroxyvitamin D concentration in a multiethnic population. Clinical Endocrinology 200868 466-472. (https://doi. org/10.1111/j.1365-2265.2007.03066.x)

65 van der Meer IM, Karamali NS, Boeke AJ, Lips P, Middelkoop BJ, Verhoeven I \& Wuister JD. High prevalence of vitamin D deficiency in pregnant non-western women in the Hague, Netherlands. American Journal of Clinical Nutrition 200684 350-353; quiz 468. (https://doi.org/10.1093/ajcn/84.1.350) 
66 Lips P. Vitamin D deficiency and secondary hyperparathyroidism in the elderly: consequences for bone loss and fractures and therapeutic implications. Endocrine Reviews 200122 477-501. (https://doi. org/10.1210/edrv.22.4.0437)

67 Quesada JM, Jans I, Benito P, Jimenez JA \& Bouillon R. Vitamin D status of elderly people in Spain. Age and Ageing 198918 392-397. (https://doi.org/10.1093/ageing/18.6.392)

68 Navarro-Valverde C \& Quesada-Gomez JM. Vitamin D deficiency in Spain. Reality or myth? Revista de Osteoporosis y Metabolismo Mineral 20146 (Supplement 1) S5-S10. (https://doi.org/10.4321/S1889836X2014000500002)

69 Bettica P, Bevilacqua M, Vago T \& Norbiato G. High prevalence of hypovitaminosis D among free-living postmenopausal women referred to an osteoporosis outpatient clinic in northern Italy for initial screening. Osteoporosis International 19999 226-229. (https:// doi.org/10.1007/s001980050141)

70 Isaia G, Giorgino R, Rini GB, Bevilacqua M, Maugeri D \& Adami S. Prevalence of hypovitaminosis D in elderly women in Italy: clinical consequences and risk factors. Osteoporosis International 200314 577-582. (https://doi.org/10.1007/s00198-003-1390-7)

71 Challa A, Ntourntoufi A, Cholevas V, Bitsori M, Galanakis E \& Andronikou S. Breastfeeding and vitamin D status in Greece during the first 6 months of life. European Journal of Pediatrics 2005164 724-729. (https://doi.org/10.1007/s00431-005-1757-1)

72 Pludowski P, Grant WB, Bhattoa HP, Bayer M, Povoroznyuk V, Rudenka E, Ramanau H, Varbiro S, Rudenka A, Karczmarewicz E et al. Vitamin D status in central Europe. International Journal of Endocrinology 20142014 589587. (https://doi. org/10.1155/2014/589587)

73 Holecki M, Zahorska-Markiewicz B, Chudek J \& Wiecek A. Changes in bone mineral density and bone turnover markers in obese women after short-term weight loss therapy during a 5-year follow-up. Polskie Archiwum Medycyny Wewnetrznej 2010120 248-254.

74 Kull MJ, Kallikorm R, Tamm A \& Lember M. Seasonal variance of 25- $(\mathrm{OH})$ vitamin $\mathrm{D}$ in the general population of Estonia, a northern European country. BMC Public Health 20099 22. (https://doi. org/10.1186/1471-2458-9-22)

75 Mayer OJ, Filipovsky J, Seidlerova J, Vanek J, Dolejsova M, Vrzalova J \& Cifkova R. The association between low 25-hydroxyvitamin D and increased aortic stiffness. Journal of Human Hypertension 201226 650-655. (https://doi.org/10.1038/jhh.2011.94)

76 Kocjan T, Tan TM-M, Conway GS \& Prelevic G. Vitamin D status in patients with osteopenia or osteoporosis - an audit of an endocrine clinic. International Journal for Vitamin and Nutrition Research 200676 307-313. (https://doi.org/10.1024/0300-9831.76.5.307)

77 Viragh E, Horvath D, Locsei Z, Kovacs L, Jager R, Varga B, Kovacs LG \& Salamonne TE. Vitamin D supply among healthy blood donors in Vas County, Hungary. Orvosi Hetilap 2012153 1629-1637. (https:// doi.org/10.1556/OH.2012.29459)

78 Bhattoa HP, Bettembuk P, Ganacharya S \& Balogh A. Prevalence and seasonal variation of hypovitaminosis $\mathrm{D}$ and its relationship to bone metabolism in community dwelling postmenopausal Hungarian women. Osteoporosis International 200415 447-451. (https://doi. org/10.1007/s00198-003-1566-1)

79 Bhattoa HP, Nagy E, More C, Kappelmayer J, Balogh A, Kalina E \& Antal-Szalmas P. Prevalence and seasonal variation of hypovitaminosis $\mathrm{D}$ and its relationship to bone metabolism in healthy Hungarian men over 50 years of age: the HunMen Study. Osteoporosis International 201324 179-186. (https://doi.org/10.1007/ s00198-012-1920-2)

80 Laktasic-Zerjavic N, Korsic M, Crncevic-Orlic Z, Kovac Z, Polasek O \& Soldo-Juresa D. Vitamin D status, dependence on age, and seasonal variations in the concentration of vitamin D in Croatian postmenopausal women initially screened for osteoporosis. Clinical Rheumatology 201029 861-867. (https://doi.org/10.1007/s10067010-1409-3)
81 Bakhtiyarova S, Lesnyak O, Kyznesova N, Blankenstein MA \& Lips P. Vitamin D status among patients with hip fracture and elderly control subjects in Yekaterinburg, Russia. Osteoporosis International 200617 441-446. (https://doi.org/10.1007/s00198-005-0006-9)

82 Kozlov A, Khabarova Y, Vershubsky G, Ateeva Y \& Ryzhaenkov V. Vitamin D status of northern indigenous people of Russia leading traditional and 'modernized' way of life. International Journal of Circumpolar Health 201473 26038. (https://doi.org/10.3402/ijch. v73.26038)

83 Meyer HE, Falch JA, Sogaard AJ \& Haug E. Vitamin D deficiency and secondary hyperparathyroidism and the association with bone mineral density in persons with Pakistani and Norwegian background living in Oslo, Norway, the Oslo Health Study. Bone 2004 35 412-417. (https://doi.org/10.1016/j.bone.2004.04.003)

84 Islam MZ, Viljakainen HT, Karkkainen MUM, Saarnio E, Laitinen K \& Lamberg-Allardt C. Prevalence of vitamin D deficiency and secondary hyperparathyroidism during winter in pre-menopausal Bangladeshi and Somali immigrant and ethnic Finnish women: associations with forearm bone mineral density. British Journal of Nutrition 2012107 277-283. (https://doi.org/10.1017/ S0007114511002893)

85 van der Meer IM, Middelkoop BJC, Boeke AJP \& Lips P. Prevalence of vitamin D deficiency among Turkish, Moroccan, Indian and subSahara African populations in Europe and their countries of origin: an overview. Osteoporosis International 201122 1009-1021. (https:// doi.org/10.1007/s00198-010-1279-1)

86 Lips P, Duong T, Oleksik A, Black D, Cummings S, Cox D \& Nickelsen T. A global study of vitamin D status and parathryoid function in postmenopausal women with osteoporosis: baseline data from the Multiple Outcomes of raloxifene Evaluation Clinical Trial. Journal of Clinical Endocrinology and Metabolism 200186 1212-1221. (https://doi.org/10.1210/jcem.86.3.7327)

87 Kuchuk NO, van Schoor NM, Pluijm SM, Chines A \& Lips P. Vitamin D status, parathyroid function, bone turnover, and BMD in postmenopausal women with osteoporosis: global perspective. Journal of Bone and Mineral Research 200924 693-701. (https://doi. org/10.1359/jbmr.081209)

88 Prentice A. Nutritional rickets around the world. Journal of Steroid Biochemistry and Molecular Biology 2013136 201-206. (https://doi org/10.1016/j.jsbmb.2012.11.018)

89 Holick MF. Vitamin D deficiency. New England Journal of Medicine 2007357 266-281. (https://doi.org/10.1056/NEJMra070553)

90 Mithal A, Wahl DA, Bonjour JP, Burckhardt P, Dawson-Hughes B, Eisman JA, El-Hajj Fuleihan G, Josse RG, Lips P, Morales-Torres J et al. Global vitamin D status and determinants of hypovitaminosis D. Osteoporosis International 200920 1807-1820. (https://doi. org/10.1007/s00198-009-0954-6)

91 van Schoor N \& Lips P. Global overview of vitamin D status. Endocrinology and Metabolism Clinics of North America 201746 845-870. (https://doi.org/10.1016/j.ecl.2017.07.002)

92 Bassil D, Rahme M, Hoteit M \& El-Hajj Fuleihan Gel-H. Hypovitaminosis D in the Middle East and North Africa: prevalence, risk factors and impact on outcomes. Dermato-Endocrinology 20135 274-298. (https://doi.org/10.4161/derm.25111)

93 Hekimsoy Z, Dinc G, Kafesciler S, Onur E, Guvenc Y, Pala T, Guclu F \& Ozmen B. Vitamin D status among adults in the Aegean region of Turkey. BMC Public Health 201010 782. (https://doi. org/10.1186/1471-2458-10-782)

94 Buyukuslu N, Esin K, Hizli H, Sunal N, Yigit P \& Garipagaoglu M. Clothing preference affects vitamin D status of young women. Nutrition Research 201434 688-693. (https://doi.org/10.1016/j. nutres.2014.07.012)

95 Parlak M, Kalay S, Kalay Z, Kirecci A, Guney O \& Koklu E. Severe vitamin $\mathrm{D}$ deficiency among pregnant women and their newborns in Turkey. Journal of Maternal-Fetal and Neonatal Medicine 201528 548-551. (https://doi.org/10.3109/14767058.2014.924103) 
96 Karaguzel G, Dilber B, Can G, Okten A, Deger O \& Holick MF. Seasonal vitamin D status of healthy schoolchildren and predictors of low vitamin D status. Journal of Pediatric Gastroenterology and Nutrition 201458 654-660. (https://doi.org/10.1097/ MPG.0000000000000274)

97 Masoompour SM, Sadegholvaad A, Larijani B \& Ranjbar-Omrani G. Effects of age and renal function on vitamin D status in men. Archives of Iranian Medicine 200811 377-381. (https://doi.org/08114/ AIM.007)

98 Hosseinpanah F,. Yarjanli M, Sheikholeslami F, Heibatollahi M, Eskandary PS \& Azizi F. Associations between vitamin D and cardiovascular outcomes; Tehran Lipid and Glucose Study. Atherosclerosis 2011218 238-242. (https://doi.org/10.1016/j. atherosclerosis.2011.05.016)

99 Hosseinpanah F, Rambod M, Hossein-nejad A, Larijani B \& Azizi F. Association between vitamin $\mathrm{D}$ and bone mineral density in Iranian postmenopausal women. Journal of Bone and Mineral Metabolism 2008 26 86-92. (https://doi.org/10.1007/s00774-007-0791-7)

100 Kaykhaei MA, Hashemi M, Narouie B, Shikhzadeh A, Rashidi H, Moulaei N \& Ghavami S. High prevalence of vitamin D deficiency in Zahedan, southeast Iran. Annals of Nutrition and Metabolism 201158 37-41. (https://doi.org/10.1159/000323749)

101 Khalesi N, Bahaeddini SM \& Shariat M. Prevalence of maternal vitamin D deficiency in neonates with delayed hypocalcaemia. Acta Medica Iranica 201250 740-745.

102 Naseh A, Ashrafzadeh S \& Rassi S. Prevalence of vitamin D deficiency in pregnant mothers in Tehran and investigating its association with serum glucose and insulin. Journal of Maternal-Fetal and Neonatal Medicine 201831 2312-2318. (https://doi.org/10.1080/14767058.201 7.1342796)

103 Torkaman M, Abolghasemi H, Amirsalari S, Beiraghdar F, Afsharpaiman S, Kavehmanesh Z \& Khosravi MH. Comparison of the vitamin D status of children younger and older than 2 years in Tehran: are supplements really necessary? International Journal of Endocrinology and Metabolism 201614 e34676. (https://doi.org/10.5812/ijem.34676)

104 Sayed-Hassan R, Abazid N \& Alourfi Z. Relationship between 25-hydroxyvitamin D concentrations, serum calcium, and parathyroid hormone in apparently healthy Syrian people. Archives of Osteoporosis 20149 176. (https://doi.org/10.1007/ s11657-014-0176-1)

105 Saliba W, Barnett O, Rennert HS \& Rennert G. The risk of all-cause mortality is inversely related to serum 25(OH)D levels. Journal of Clinical Endocrinology and Metabolism 201297 2792-2798. (https:// doi.org/10.1210/jc.2012-1747)

106 Steinvil A, Leshem-Rubinow E, Berliner S, Justo D, Finn T, Ishshalom M, Birati EY, Shalev V, Sheinberg B \& Rogowski O. Vitamin $\mathrm{D}$ deficiency prevalence and cardiovascular risk in Israel. European Journal of Clinical Investigation 201141 263-268. (https://doi. org/10.1111/j.1365-2362.2010.02403.x)

107 Oren Y, Shapira Y, Agmon-Levin N, Kivity S, Zafrir Y, Altman A, Lerner A \& Shoenfeld Y. Vitamin D insufficiency in a sunny environment: a demographic and seasonal analysis. Israel Medical Association Journal 201012 751-756.

108 Korchia G, Amitai Y, Moshe G, Korchia L, Tenenbaum A, Rosenblum J \& Schechter A. Vitamin D deficiency in children in Jerusalem: the need for updating the recommendation for supplementation. Israel Medical Association Journal 201315 333-338.

109 Batieha A, Khader Y, Jaddou H, Hyassat D, Batieha Z, Khateeb M, Belbisi A \& Ajlouni K. Vitamin D status in Jordan: dress style and gender discrepancies. Annals of Nutrition and Metabolism 201158 10-18. (https://doi.org/10.1159/000323097)

110 Nichols EK, Khatib IM, Aburto NJ, Sullivan KM, Scanlon KS, Wirth JP \& Serdula MK. Vitamin D status and determinants of deficiency among non-pregnant Jordanian women of reproductive age. European Journal of Clinical Nutrition 201266 751-756. (https://doi. org/10.1038/ejcn.2012.25)
111 Nichols EK, Khatib IM, Aburto NJ, Serdula MK, Scanlon KS, Wirth JP \& Sullivan KM. Vitamin D status and associated factors of deficiency among Jordanian children of preschool age. European Journal of Clinical Nutrition 201569 90-95. (https://doi.org/10.1038/ ejcn.2014.142)

112 Mallah EM, Hamad MF, Elmanaseer MA, Qinna NA, Idkaidek NM, Arafat TA \& Matalka KZ. Plasma concentrations of 25-hydroxyvitamin D among Jordanians: effect of biological and habitual factors on vitamin D status. BMC Clinical Pathology $2011 \mathbf{1 1}$ 8. (https://doi.org/10.1186/1472-6890-11-8)

113 Khuri-Bulos N, Lang RD, Blevins M, Kudyba K, Lawrence L, Davidson M, Faouri S \& Halasa NB. Vitamin D deficiency among newborns in Amman, Jordan. Global Journal of Health Science 20136 162-171. (https://doi.org/10.5539/gihs.v6n1p162)

114 Hoteit M, Al-Shaar L, Yazbeck C, Bou Sleiman M, Ghalayini T \& Fuleihan Gel Gel-H. Hypovitaminosis D in a sunny country: time trends, predictors, and implications for practice guidelines. Metabolism 201463 968-978. (https://doi.org/10.1016/j. metabol.2014.04.009)

115 Arabi A, Baddoura R, El-Rassi R \& El-Hajj Fuleihan G. Age but not gender modulates the relationship between PTH and vitamin D. Bone 201047 408-412. (https://doi.org/10.1016/j.bone.2010.05.002)

116 Alyahya KO. Vitamin D levels in schoolchildren: a cross-sectional study in Kuwait. BMC Pediatrics 201717 213. (https://doi. org/10.1186/s12887-017-0963-0)

117 Molla AM, Al Badawi M, Hammoud MS, Molla AM, Shukkur M, Thalib L \& Eliwa MS. Vitamin D status of mothers and their neonates in Kuwait. Pediatrics International 200547 649-652. (https://doi. org/10.1111/j.1442-200x.2005.02141.x)

118 Ardawi MS, Sibiany AM, Bakhsh TM, Qari MH \& Maimani AA. High prevalence of vitamin D deficiency among healthy Saudi Arabian men: relationship to bone mineral density, parathyroid hormone, bone turnover markers, and lifestyle factors. Osteoporosis International 201223 675-686. (https://doi.org/10.1007/s00198-011-1606-1)

119 Al Shaikh AM, Abaalkhail B, Soliman A, Kaddam I, Aseri K, Al-Saleh Y, Al Qarni A, Al Shuaibi A, Al Tamimi W \& Mukhtar AM. Prevalence of vitamin D deficiency and calcium homeostasis in Saudi children. Journal of Clinical Research in Pediatric Endocrinology 20168 461-467. (https://doi.org/10.4274/jcrpe.3301)

120 Al-Faris NA. High prevalence of vitamin D deficiency among pregnant Saudi women. Nutrients 20168 77. (https://doi. org/10.3390/nu8020077)

121 Rajah J, Haq A \& Pettifor JM. Vitamin D and calcium status in urban children attending an ambulatory clinic service in the United Arab Emirates. Dermato-Endocrinology 20124 39-43. (https://doi. org/10.4161/derm.18250)

122 Al Anouti F, Thomas J, Abdel-Wareth L, Rajah J, Grant WB \& Haq A. Vitamin D deficiency and sun avoidance among university students at Abu Dhabi, United Arab Emirates. Dermato-Endocrinology 20113 235-239. (https://doi.org/10.4161/derm.3.4.16881)

123 Golbahar J, Al-Saffar N, Altayab Diab D, Al-Othman S, Darwish A \& Al-Kafaji G. Predictors of vitamin D deficiency and insufficiency in adult Bahrainis: a cross-sectional study. Public Health Nutrition 2014 17 732-738. (https://doi.org/10.1017/S136898001300030X)

124 El-Menyar A, Rahil A, Dousa K, Ibrahim W, Ibrahim T, Khalifa R \& Abdel Rahman MO. Low vitamin D and cardiovascular risk factors in males and females from a sunny, rich country. Open Cardiovascular Medicine Journal 20126 76-80. (https://doi.org/10.2174/1874192401 206010076)

125 Botros RM, Sabry IM, Abdelbaky RS, Eid YM, Nasr MS \& Hendawy LM. Vitamin D deficiency among healthy Egyptian females. Endocrinologia y Nutricion 201562 314-321. (https://doi. org/10.1016/j.endonu.2015.03.010)

126 Ayadi ID, Nouaili EB, Talbi E, Ghdemssi A, Rached C, Bahlous A, Gammoudi A, Hamouda SB, Bouguerra B, Bouzid K et al. Prevalence of vitamin D deficiency in mothers and their newborns in a Tunisian 
population. International Journal of Gynaecology and Obstetrics 2016 133 192-195. (https://doi.org/10.1016/j.ijgo.2015.09.029)

127 Djennane M, Lebbah S, Roux C, Djoudi H, Cavalier E \& Souberbielle JC. Vitamin D status of schoolchildren in Northern Algeria, seasonal variations and determinants of vitamin D deficiency. Osteoporosis International 201425 1493-1502. (https://doi. org/10.1007/s00198-014-2623-7)

128 El Maghraoui A, Ouzzif Z, Mounach A, Rezqi A, Achemlal L, Bezza A, Tellal S, Dehhaoui M \& Ghozlani I. Hypovitaminosis $\mathrm{D}$ and prevalent asymptomatic vertebral fractures in Moroccan postmenopausal women. BMC Women's Health 201212 11. (https:// doi.org/10.1186/1472-6874-12-11)

129 Atli T, Gullu S, Uysal AR \& Erdogan G. The prevalence of vitamin $\mathrm{D}$ deficiency and effects of ultraviolet light on vitamin D levels in elderly Turkish population. Archives of Gerontology and Geriatrics 2005 40 53-60. (https://doi.org/10.1016/j.archger.2004.05.006)

130 Alagol F, Shihadeh Y, Boztepe H, Tanakol R, Yarman S, Azizlerli H \& Sandalci O. Sunlight exposure and vitamin D deficiency in Turkish women. Journal of Endocrinological Investigation 200023 173-177. (https://doi.org/10.1007/BF03343702)

131 Mishal AA. Effects of different dress styles on vitamin D levels in healthy young Jordanian women. Osteoporosis International 200112 931-935. (https://doi.org/10.1007/s001980170021)

132 MacLaughlin J \& Holick MF. Aging decreases the capacity of human skin to produce vitamin D3. Journal of Clinical Investigation 198576 1536-1538. (https://doi.org/10.1172/JCI112134)

133 Lips P, Netelenbos JC, Jongen MJ, van Ginkel FC, Althuis AL, van Schaik CL, van der Vijgh WJ, Vermeiden JP \& van der Meer C. Histomorphometric profile and vitamin D status in patients with femoral neck fracture. Metabolic Bone Disease and Related Research 19824 85-93. (https://doi.org/10.1016/0221-8747(82)90021-2)

134 Brustad M, Sandanger T, Aksnes L \& Lund E. Vitamin D status in a rural population of northern Norway with high fish liver consumption. Public Health Nutrition 20047 783-789. (https://doi. org/10.1079/PHN2004605)

135 Brustad M, Alsaker E, Engelsen O, Aksnes L \& Lund E. Vitamin D status of middle-aged women at $65-71$ degrees $\mathrm{N}$ in relation to dietary intake and exposure to ultraviolet radiation. Public Health Nutrition 20047 327-335. (https://doi.org/10.1079/PHN2003536)

136 Adami S, Bertoldo F, Braga V, Fracassi E, Gatti D, Gandolini G, Minisola S \& Battista Rini G. 25-Hydroxy vitamin D levels in healthy premenopausal wome: association with bone turnover markers and bone mineral density. Bone 200945 423-426. (https://doi. org/10.1016/j.bone.2009.05.012)

137 Matsuoka LY, Wortsman J, Haddad JG, Kolm P \& Hollis BW. Racial pigmentation and the cutaneous synthesis of vitamin D. Archives of Dermatology 1991127 536-538. (https://doi.org/10.1001/ archderm.1991.04510010104011)

138 Kiely M \& Black LJ. Dietary strategies to maintain adequacy of circulating 25-hydroxyvitamin D concentrations. Scandinavian Journal of Clinical and Laboratory Investigation. Supplementum 2012 243 14-23. (https://doi.org/10.3109/00365513.2012.681893)

139 Thorgeirsdottir H, Valgeirsdottir H, Gunnarsdottir I, Gisladottir E, Gunnarsdottir BE \& Thorsdottir I. Icelandic National Nutrition Survey 2010-2011 Main Results. Reykjavik: Directorate of Health, 2012.

140 Landlæknis E. Ráðleggingar um matarøði og noeringarefni fyrir fullorðna og börn frá tveggja ára aldri., 2010 ed. Iceland: Landlaeknir, 2010.

141 Meyer HE, Brunvand L, Brustad M, Holvik K, Johansson L \& Paulsen JE. Tiltak for å sikre en god vitamin D-status i befolkningen, pp 1-88. Ed S-o Helsedirektoratet. Oslo, 2006.

142 Brustad M, Braaten T \& Lund E. Predictors for cod-liver oil supplement use - the Norwegian Women and Cancer Study. European Journal of Clinical Nutrition 200458 128-136. (https://doi. org/10.1038/sj.ejcn.1601759)

143 Ovesen L, Andersen R \& Jakobsen J. Geographical differences in vitamin D status, with particular reference to European countries.
Proceedings of the Nutrition Society 200362 813-821. (https://doi. org/10.1079/PNS2003297)

144 NORDEN. Nordic Nutrition Recommendations, 5th ed (NNR5)-vitamin D, 2012.

145 Becker W \& Pearson M. Riksmaten 1997-1998. Uppsala: Livsmedelsverket, 2004.

146 Enghardt Barbieri H, Pearson M \& Becker W. Riksmaten-Barn. Livsmedels-och Näringsintag Bland Barn i Sverige. Uppsala: Ord\&Form, 2003.

147 Helldán A, Raulio S, Kosola M, Tapanainen H, Ovaskainen M-L \& Virtanen S. Finravinto 2012-Tutkimus - The National FINDIET 2012 Survey, p 187. Helsinki, Finland, 2013.

148 Kyttala P, Erkkola M, Kronberg-Kippila C, Tapanainen H, Veijola R, Simell O, Knip M \& Virtanen SM. Food consumption and nutrient intake in Finnish 1-6-year-old children Finnish. Public Health Nutrition 201013 947-956. (https://doi.org/10.1017/ S136898001000114X

149 Thuesen B, Husemoen L, Fenger M, Jakobsen J, Schwarz P, Toft U, Ovesen L, Jorgensen T \& Linneberg A. Determinants of vitamin D status in a general population of Danish adults. Bone $2012 \mathbf{5 0}$ 605-610. (https://doi.org/10.1016/j.bone.2011.12.016)

150 Black LJ, Walton J, Flynn A \& Kiely M. Adequacy of vitamin D intakes in children and teenagers from the base diet, fortified foods and supplements. Public Health Nutrition 201417 721-731. (https:// doi.org/10.1017/S1368980013000359)

151 Black LJ, Walton J, Flynn A, Cashman KD \& Kiely M. Small increments in vitamin $\mathrm{D}$ intake by Irish adults over a decade show that strategic initiatives to fortify the food supply are needed. Journal of Nutrition 2015145 969-976. (https://doi.org/10.3945/jn.114.209106)

152 Hennessy Á, Browne F, Kiely M, Walton J \& Flynn A. The role of fortified foods and nutritional supplements in increasing vitamin D intake in Irish preschool children. European Journal of Nutrition 2017 56 1219-1231. (https://doi.org/10.1007/s00394-016-1171-7)

153 United Kingdom Government. National Diet and Nutrition Survey (NDNS) Rolling Program, 2018.

154 Hill TR, O’Brien MM, Cashman KD, Flynn A \& Kiely M. Vitamin $\mathrm{D}$ intakes in 18-64-y-old Irish adults. European Journal of Clinical Nutrition 200458 1509-1517. (https://doi.org/10.1038/ sj.ejcn.1602001)

155 Roman Vinas B, Ribas Barba L, Ngo J, Gurinovic M, Novakovic R, Cavelaars A, de Groot LC, van't Veer P, Matthys C \& Serra-Majem L. Projected prevalence of inadequate nutrient intakes in Europe. Annals of Nutrition and Metabolism 201159 84-95. (https://doi. org/10.1159/000332762)

156 Lips P, van Ginkel FC, Jongen MJ, Rubertus F, van der Vijgh WJ \& Netelenbos JC. Determinants of vitamin D status in patients with hip fracture and in elderly control subjects. American Journal of Clinical Nutrition 198746 1005-1010. (https://doi.org/10.1093/ ajcn/46.6.1005)

157 Verkaik-Kloosterman J, Dodd KW, Dekkers AL, van 't Veer P \& Ocke MC. A three-part, mixed-effects model to estimate the habitual total vitamin D intake distribution from food and dietary supplements in Dutch young children. Journal of Nutrition 2011141 2055-2063. (https://doi.org/10.3945/jn.111.142398)

158 Touvier M, Deschasaux M, Montourcy M, Sutton A, Charnaux N, Kesse-Guyot E, Assmann KE, Fezeu L, Latino-Martel P, DruesnePecollo $\mathrm{N}$ et al. Determinants of vitamin D status in Caucasian adults: influence of sun exposure, dietary intake, sociodemographic, lifestyle, anthropometric, and genetic factors. Journal of Investigative Dermatology 2015135 378-388. (https://doi.org/10.1038/ jid.2014.400)

159 Jungert A, Spinneker A, Nagel A \& Neuhauser-Berthold M. Dietary intake and main food sources of vitamin D as a function of age, sex, vitamin D status, body composition, and income in an elderly German cohort. Food and Nutrition Research 201458 1-8. (https://doi. org/10.3402/fnr.v58.23632) 
160 Rabenberg M, Scheidt-Nave C, Busch MA, Rieckmann N, Hintzpeter B \& Mensink GB. Vitamin D status among adults in Germany - results from the German Health Interview and Examination Survey for Adults (DEGS1). BMC Public Health 201515 641. (https://doi.org/10.1186/s12889-015-2016-7)

161 Koenig J \& Elmadfa I. Status of calcium and vitamin D of different population groups in Austria. International Journal for Vitamin and Nutrition Research 200070 214-220. (https://doi.org/10.1024/03009831.70.5.214)

162 Novakovic R, Cavelaars AEJM, Bekkering GE, Roman-Vinas B, Ngo J, Gurinovic M, Glibetic M, Nikolic M, Golesorkhi M, Warthon Medina $\mathrm{M}$ et al. Micronutrient intake and status in Central and Eastern Europe compared with other European countries, results from the EURRECA network. Public Health Nutrition 201316 824-840. (https://doi.org/10.1017/s-1368-980012004077)

163 Jenab M, Salvini S, van Gils CH, Brustad M, Shakya-Shrestha S, Buijsse B, Verhagen H, Touvier M, Biessy C, Wallstrom P et al. Dietary intakes of retinol, beta-carotene, vitamin $\mathrm{D}$ and vitamin $\mathrm{E}$ in the European Prospective Investigation into Cancer and Nutrition cohort. European Journal of Clinical Nutrition 200963 (Supplement 4) S150-S178. (https://doi.org/10.1038/ejcn.2009.79)

164 Bilici S, Saglam F, Beyhan Y, Barut-Uyar B, Dikmen D, Goktas Z, Attar AJ, Mucka P \& Uyar MF. Energy expenditure and nutritional status of coal miners: a cross-sectional study. Archives of Environmental and Occupational Health 201671 293-299. (https://doi.org/10.1080/1 9338244.2015.1095152)

165 Ejtahed HS, Shab-Bidar S, Hosseinpanah F, Mirmiran P \& Azizi F. Estimation of vitamin D intake based on a scenario for fortification of dairy products with vitamin $\mathrm{D}$ in a Tehranian population, Iran. Journal of the American College of Nutrition 201635 383-391. (https:// doi.org/10.1080/07315724.2015.1022269)

166 Khashayar P, Qorbani M, Keshtkar A, Khashayar P, Ziaee A \& Larijani B. Awareness of osteoporosis among female head of household: an Iranian experience. Archives of Osteoporosis 201712 36. (https://doi.org/10.1007/s11657-017-0330-7)

167 Sabour H, Hossein-Nezhad A, Maghbooli Z, Madani F, Mir E \& Larijani B. Relationship between pregnancy outcomes and maternal vitamin D and calcium intake: a cross-sectional study. Gynecological Endocrinology 200622 585-589. (https://doi. org/10.1080/09513590601005409)

168 Feizabad E, Hossein-Nezhad A, Maghbooli Z, Ramezani M, Hashemian R \& Moattari S. Impact of air pollution on vitamin D deficiency and bone health in adolescents. Archives of Osteoporosis 201712 34. (https://doi.org/10.1007/s11657-017-0323-6)

169 Kelishadi R, Moeini R, Poursafa P, Farajian S, Yousefy H \& OkhovatSouraki AA. Independent association between air pollutants and vitamin D deficiency in young children in Isfahan, Iran. Paediatrics and International Child Health 201434 50-55. (https://doi.org/10.117 9/2046905513Y.0000000080)

170 Zaghloul S, Al-Hooti SN, Al-Hamad N, Al-Zenki S, Alomirah H, Alayan I, Al-Attar H, Al-Othman A, Al-Shami E, Al-Somaie M et al. Evidence for nutrition transition in Kuwait: over-consumption of macronutrients and obesity. Public Health Nutrition 201316 596-607. (https://doi.org/10.1017/S1368980012003941)

171 Gannage-Yared MH, Chemali R, Yaacoub N \& Halaby G. Hypovitaminosis D in a sunny country: relation to lifestyle and bone markers. Journal of Bone and Mineral Research 200015 1856-1862. (https://doi.org/10.1359/jbmr.2000.15.9.1856)

172 Papazian T, Hout H, Sibai D, Helou N, Younes H, El Osta N \& Khabbaz LR. Development, reproducibility and validity of a food frequency questionnaire among pregnant women adherent to the Mediterranean dietary pattern. Clinical Nutrition 201635 1550-1556. (https://doi.org/10.1016/j.clnu.2016.04.015)

173 Salameh K, Al-Janahi NS, Reedy AM \& Dawodu A. Prevalence and risk factors for low vitamin D status among breastfeeding mother-infant dyads in an environment with abundant sunshine.
International Journal of Women's Health 20168 529-535. (https://doi. org/10.2147/IJWH.S107707)

174 Narchi H, Kochiyil J, Al Hamad S, Yasin J, Laleye L \& Al Dhaheri A. Hypovitaminosis D in adolescent females - an analytical cohort study in the United Arab Emirates. Paediatrics and International Child Health 201535 36-43. (https://doi.org/10.1179/2046905514Y.0000000144)

175 Alzaheb RA \& Al-Amer O. Prevalence and predictors of hypovitaminosis D among female university students in Tabuk, Saudi Arabia. Clinical Medicine Insights: Women's Health 201710 1179562X17702391. (https://doi.org/10.1177/1179562X17702391)

176 Bezrati I, Ben Fradj MKB, Ouerghi N, Feki M, Chaouachi A \& Kaabachi N. Vitamin D inadequacy is widespread in Tunisian active boys and is related to diet but not to adiposity or insulin resistance. Libyan Journal of Medicine 201611 31258. (https://doi.org/10.3402/ ljm.v11.31258)

177 Hwalla N, Al Dhaheri AS, Radwan H, Alfawaz HA, Fouda MA, Al-Daghri NM, Zaghloul S \& Blumberg JB. The prevalence of micronutrient deficiencies and inadequacies in the Middle East and approaches to interventions. Nutrients 20179 E229. (https://doi. org/10.3390/nu9030229)

178 Shea MK, Benjamin EJ, Dupuis J, Massaro JM, Jacques PF, D'Agostino RB Sr, Ordovas JM, O'Donnell CJ, Dawson-Hughes B, Vasan RS et al. Genetic and non-genetic correlates of vitamins $\mathrm{K}$ and D. European Journal of Clinical Nutrition 200963 458-464. (https:// doi.org/10.1038/sj.ejcn.1602959)

179 Wang TJ, Zhang F, Richards JB, Kestenbaum B, van Meurs JB, Berry D, Kiel DP, Streeten EA, Ohlsson C, Koller DL et al. Common genetic determinants of vitamin D insufficiency: a genome-wide association study. Lancet 2010376 180-188. (https://doi.org/10.1016/S01406736(10)60588-0)

180 Ahn J, Yu K, Stolzenberg-Solomon R, Simon KC, McCullough ML, Gallicchio L, Jacobs EJ, Ascherio A, Helzlsouer K, Jacobs KB et al. Genome-wide association study of circulating vitamin D levels. Human Molecular Genetics 201019 2739-2745. (https://doi. org/10.1093/hmg/ddq155)

181 Signorello LB, Shi J, Cai Q, Zheng W, Williams SM, Long J, Cohen SS, Li G, Hollis BW, Smith JR et al. Common variation in vitamin D pathway genes predicts circulating 25-hydroxyvitamin D levels among African Americans. PLoS ONE 20116 e28623. (https://doi. org/10.1371/journal.pone.0028623)

182 Anderson LN, Cotterchio M, Knight JA, Borgida A, Gallinger S \& Cleary SP. Genetic variants in vitamin D pathway genes and risk of pancreas cancer; results from a population-based case-control study in Ontario, Canada. PLOS ONE 20138 e66768. (https://doi. org/10.1371/journal.pone.0066768)

183 Trummer O, Schwetz V, Walter-Finell D, Lerchbaum E, Renner W, Gugatschka M, Dobnig H, Pieber TR \& Obermayer-Pietsch B. Allelic determinants of vitamin D insufficiency, bone mineral density, and bone fractures. Journal of Clinical Endocrinology and Metabolism 2012 97 E1234-E1240. (https://doi.org/10.1210/jc.2011-3088)

184 Bouillon R. Genetic and environmental determinants of vitamin D status. Lancet 2010376 148-149. (https://doi.org/10.1016/S01406736(10)60635-6)

185 Bouillon R, Jones K \& Schoenmakers I. Vitamin D-binding protein and vitamin D in blacks and whites. New England Journal of Medicine 2014370 879. (https://doi.org/10.1056/NEJMc1315850)

186 Powe CE, Evans MK, Wenger J, Zonderman AB, Berg AH, Nalls M, Tamez H, Zhang D, Bhan I, Karumanchi SA et al. Vitamin D-binding protein and vitamin D status of black Americans and white Americans. New England Journal of Medicine 2013369 1991-2000. (https://doi.org/10.1056/NEJMoa1306357)

187 Henderson CM, Lutsey PL, Misialek JR, Laha TJ, Selvin E, Eckfeldt JH $\&$ Hoofnagle AN. Measurement by a novel LC-MS/MS methodology reveals similar serum concentrations of vitamin D-binding protein in blacks and whites. Clinical Chemistry 201662 179-187. (https://doi. org/10.1373/clinchem.2015.244541) 
188 Nielson CM, Jones KS, Chun RF, Jacobs JM, Wang Y, Hewison M, Adams JS, Swanson CM, Lee CG, Vanderschueren D et al. Free 25-hydroxyvitamin D: impact of vitamin D binding protein assays on racial-genotypic associations. Journal of Clinical Endocrinology and Metabolism 2016101 2226-2234. (https://doi.org/10.1210/ jc.2016-1104)

189 Bouillon R. The power of mass spectroscopy as arbiter for immunoassays. Clinical Chemistry 201662 6-8. (https://doi. org/10.1373/clinchem.2015.248484)

190 Schwartz JB, Lai J, Lizaola B, Kane L, Markova S, Weyland P, Terrault NA, Stotland N \& Bikle D. A comparison of measured and calculated free $25(\mathrm{OH})$ vitamin D levels in clinical populations. Journal of Clinical Endocrinology and Metabolism 201499 1631-1637. (https://doi.org/10.1210/jc.2013-3874)

191 Dagnelie PC, Vergote FJVR, Vanstaveren WA, Vandenberg H, Dingjan PG \& Hautvast JGAJ. High prevalence of rickets in infants on macrobiotic diets. American Journal of Clinical Nutrition $1990 \mathbf{5 1}$ 202-208. (https://doi.org/10.1093/ajcn/51.2.202)

192 Beck-Nielsen SS, Jensen TK, Gram J, Brixen K \& Brock-Jacobsen B. Nutritional rickets in Denmark: a retrospective review of children's medical records from 1985 to 2005. European Journal of Pediatrics 2009168 941-949. (https://doi.org/10.1007/s00431-008-0864-1)

193 Lieben L, Masuyama R, Torrekens S, Van Looveren R, Schrooten J, Baatsen P, Lafage-Proust MH, Dresselaers T, Feng JQ, Bonewald LF et al. Normocalcemia is maintained in mice under conditions of calcium malabsorption by vitamin D-induced inhibition of bone mineralization. Journal of Clinical Investigation 2012122 1803-1815. (https://doi.org/10.1172/JCI45890)

194 Eisman JA \& Bouillon R. Vitamin D: direct effects of vitamin D metabolites on bone: lessons from genetically modified mice. BoneKEy Reports 20143 499. (https://doi.org/10.1038/ bonekey.2013.233)

195 Bischoff-Ferrari HA, Willett WC, Wong JB, Giovannucci E, Dietrich T \& Dawson-Hughes B. Fracture prevention with vitamin D supplementation: a meta-analysis of randomized controlled trials. JAMA 2005293 2257-2264. (https://doi.org/10.1001/ jama.293.18.2257)

196 Bischoff-Ferrari HA, Willett WC, Orav EJ, Lips P, Meunier PJ, Lyons RA, Flicker L, Wark J, Jackson RD, Cauley JA et al. A pooled analysis of vitamin $\mathrm{D}$ dose requirements for fracture prevention. New England Journal of Medicine 2012367 40-49. (https://doi.org/10.1056/ NEJMoa1109617)

197 Bischoff-Ferrari HA, Willett WC, Wong JB, Stuck AE, Staehelin HB, Orav EJ, Thoma A, Kiel DP \& Henschkowski J. Prevention of nonvertebral fractures with oral vitamin $\mathrm{D}$ and dose dependency: a meta-analysis of randomized controlled trials. Archives of Internal Medicine 2009169 551-561. (https://doi.org/10.1001/ archinternmed.2008.600)

198 Boonen S, Lips P, Bouillon R, Bischoff-Ferrari HA, Vanderschueren D $\&$ Haentjens P. Need for additional calcium to reduce the risk of hip fracture with vitamin D supplementation: evidence from a comparative metaanalysis of randomized controlled trials. Journal of Clinical Endocrinology and Metabolism 200792 1415-1423. (https:// doi.org/10.1210/jc.2006-1404)

199 Avenell A, Mak JC \& O'Connell D. Vitamin D and vitamin D analogues for preventing fractures in post-menopausal women and older men. Cochrane Database of Systematic Reviews 2014 CD000227. (https://doi.org/10.1002/14651858.CD000227.pub4)

200 Lips P, Gielen E \& van Schoor NM. Vitamin D supplements with or without calcium to prevent fractures. BoneKEy Reports 20143512. (https://doi.org/10.1038/bonekey.2014.7)

201 Boonen S, Bischoff-Ferrari HA, Cooper C, Lips P, Ljunggren O, Meunier PJ \& Reginster JY. Addressing the musculoskeletal components of fracture risk with calcium and vitamin D: a review of the evidence. Calcified Tissue International 200678 257-270. (https:// doi.org/10.1007/s00223-005-0009-8)
202 Drake MT. Vitamin D and the goldilocks principle: too little, too much, or just right? Journal of Clinical Endocrinology and Metabolism 201499 1164-1166. (https://doi.org/10.1210/jc.2014-1350)

203 Autier P, Boniol M, Pizot C \& Mullie P. Vitamin D status and ill health: a systematic review. Lancet. Diabetes and Endocrinology 20142 76-89. (https://doi.org/10.1016/S2213-8587(13)70165-7)

204 Bolland MJ, Grey A, Gamble GD \& Reid IR. The effect of vitamin D supplementation on skeletal, vascular, or cancer outcomes: a trial sequential meta-analysis. Lancet Diabetes and Endocrinology 20142 307-320. (https://doi.org/10.1016/S2213-8587(13)70212-2)

205 Bolland MJ, Grey A \& Avenell A. Effects of vitamin D supplementation on musculoskeletal health: a systematic review, meta-analysis, and trial sequential analysis. Lancet. Diabetes and Endocrinology 20186 847-858. (https://doi.org/10.1016/S22138587(18)30265-1)

206 Bouillon R, Carmeliet G, Verlinden L, van Etten E, Verstuyf A, Luderer HF, Lieben L, Mathieu C \& Demay M. Vitamin D and human health: lessons from vitamin D receptor null mice. Endocrine Reviews 200829 726-776. (https://doi.org/10.1210/er.2008-0004)

207 Rosen CJ, Adams JS, Bikle DD, Black DM, Demay MB, Manson JE, Murad MH \& Kovacs CS. The nonskeletal effects of vitamin D: an Endocrine Society scientific statement. Endocrine Reviews 201233 456-492. (https://doi.org/10.1210/er.2012-1000)

208 Bouillon R, Marcocci C, Carmeliet G, Bikle D, White JH, DawsonHughes B, Lips P, Munns CF, Lazaretti-Castro M, Giustina A et al. Skeletal and extra-skeletal actions of vitamin D: current evidence and outstanding questions. Endocrine Reviews 2018 Epub. (https://doi. org/10.1210/er.2018-00126)

209 Rejnmark L, Avenell A, Masud T, Anderson F, Meyer HE, Sanders KM, Salovaara K, Cooper C, Smith HE, Jacobs ET et al. Vitamin D with calcium reduces mortality: patient level pooled analysis of 70528 patients from eight major vitamin D trials. Journal of Clinical Endocrinology and Metabolism 201297 2670-2681. (https://doi. org/10.1210/jc.2011-3328)

210 Wang Y \& DeLuca HF. Is the vitamin D receptor found in the muscle? Endocrinology 2011152 354-363. (https://doi.org/10.1210/ en.2010-1109)

211 Bischoff HA, Borchers M, Gudat F, Duermueller U, Theiler R, Stahelin HB \& Dick W. In situ detection of 1,25-dihydroxyvitamin D3 receptor in human skeletal muscle tissue. Histochemical Journal 200133 19-24. (https://doi.org/10.1023/A:1017535728844)

212 Bischoff-Ferrari HA, Borchers M, Gudat F, Durmuller U, Stahelin HB $\&$ Dick W. Vitamin D receptor expression in human muscle tissue decreases with age. Journal of Bone and Mineral Research 200419 265-269. (https://doi.org/10.1359/jbmr.2004.19.2.265)

213 Boland R. Role of vitamin D in skeletal muscle function. Endocrine Reviews 19867 434-448. (https://doi.org/10.1210/edrv-7-4-434)

214 Costa EM, Blau HM \& Feldman D. 1,25-Dihydroxyvitamin D3 receptors and hormonal responses in cloned human skeletal muscle cells. Endocrinology 1986119 2214-2220. (https://doi.org/10.1210/ endo-119-5-2214)

215 Simpson RU, Thomas GA \& Arnold AJ. Identification of 1,25-dihydroxyvitamin D3 receptors and activities in muscle. Journal of Biological Chemistry $19852608882-8891$.

216 Ceglia L, da Silva Morais M, Park LK, Morris E, Harris SS, Bischoff-Ferrari HA, Fielding RA \& Dawson-Hughes B. Multi-step immunofluorescent analysis of vitamin D receptor loci and myosin heavy chain isoforms in human skeletal muscle. Journal of Molecular Histology 201041 137-142. (https://doi.org/10.1007/s10735-010-9270-x)

217 Girgis CM, Mokbel N, Cha KM, Houweling PJ, Abboud M, Fraser DR, Mason RS, Clifton-Bligh RJ \& Gunton JE. The vitamin D receptor (VDR) is expressed in skeletal muscle of male mice and modulates 25-hydroxyvitamin D (25OHD) uptake in myofibers. Endocrinology 2014155 3227-3237. (https://doi.org/10.1210/en.2014-1016)

218 Bischoff-Ferrari HA, Dawson-Hughes B, Staehelin HB, Orav JE, Stuck AE, Theiler R, Wong JB, Egli A, Kiel DP \& Henschkowski J. 
Fall prevention with supplemental and active forms of vitamin D: a meta-analysis of randomised controlled trials. BMJ 2009339 b3692. (https://doi.org/10.1136/bmj.b3692)

219 Bolland MJ, Grey A, Gamble GD \& Reid IR. Vitamin D supplementation and falls: a trial sequential meta-analysis. Lancet Diabetes and Endocrinology 20142 573-580. (https://doi.org/10.1016/ S2213-8587(14)70068-3)

220 Bischoff-Ferrari HA. Relevance of vitamin D in muscle health. Reviews in Endocrine and Metabolic Disorders 201213 71-77. (https://doi. org/10.1007/s11154-011-9200-6)

221 Sanders KM, Stuart AL, Williamson EJ, Simpson JA, Kotowicz MA, Young D \& Nicholson GC. Annual high-dose oral vitamin D and falls and fractures in older women: a randomized controlled trial. JAMA 2010303 1815-1822. (https://doi.org/10.1001/jama.2010.594)

222 Bischoff-Ferrari HA, Dawson-Hughes B, Orav EJ, Staehelin HB, Meyer OW, Theiler R, Dick W, Willett WC \& Egli A. Monthly highdose vitamin $\mathrm{D}$ treatment for the prevention of functional decline: a randomized clinical trial. JAMA Internal Medicine 2016176 175-183. (https://doi.org/10.1001/jamainternmed.2015.7148)

223 Gallagher JC, Sai A, Templin T \& Smith L. Dose response to vitamin D supplementation in postmenopausal women: a randomized trial. Annals of Internal Medicine 2012156 425-437. (https://doi. org/10.7326/0003-4819-156-6-201203200-00005)

224 Bischoff-Ferrari HA, Dawson-Hughes B, Orav EJ, Staehelin HB, Meyer OW, Theiler R, Dick W, Willett WC \& Egli A. Monthly highdose vitamin $\mathrm{D}$ treatment for the prevention of functional decline: a randomized clinical trial. JAMA Internal Medicine 2016176 175-183. (https://doi.org/10.1001/jamainternmed.2015.7148)

225 Smith LM, Gallagher JC \& Suiter C. Medium doses of daily vitamin D decrease falls and higher doses of daily vitamin D3 increase falls: a randomized clinical trial. Journal of Steroid Biochemistry and Molecular Biology 2017173 317-322. (https://doi.org/10.1016/j. jsbmb.2017.03.015)

226 Wehr E, Pilz S, Boehm BO, Marz W \& Obermayer-Pietsch B. Association of vitamin D status with serum androgen levels in men. Clinical Endocrinology 201073 243-248. (https://doi.org/10.1111/ j.1365-2265.2009.03777.x)

227 Tak YJ, Lee JG, Kim YJ, Park NC, Kim SS, Lee S, Cho BM, Kong EH, Jung DW \& Yi YH. Serum 25-hydroxyvitamin D levels and testosterone deficiency in middle-aged Korean men: a cross-sectional study. Asian Journal of Andrology 201517 324-328. (https://doi. org/10.4103/1008-682X.142137)

228 Anic GM, Albanes D, Rohrmann S, Kanarek N, Nelson WG, Bradwin G, Rifai N, McGlynn KA, Platz EA \& Mondul AM. Association between serum 25-hydroxyvitamin D and serum sex steroid hormones among men in NHANES. Clinical Endocrinology 201685 258-266. (https://doi.org/10.1111/cen.13062)

229 Lee DM, Tajar A, Pye SR, Boonen S, Vanderschueren D, Bouillon R, O'Neill TW, Bartfai G, Casanueva FF, Finn JD et al. Association of hypogonadism with vitamin D status: the European Male Ageing Study. European Journal of Endocrinology 2012166 77-85. (https://doi. org/10.1530/EJE-11-0743)

230 Hofer D, Munzker J, Schwetz V, Ulbing M, Hutz K, Stiegler P, Zigeuner R, Pieber TR, Muller H \& Obermayer-Pietsch B. Testicular synthesis and vitamin D action. Journal of Clinical Endocrinology and Metabolism 201499 3766-3773. (https://doi.org/10.1210/ jc.2014-1690)

231 Pilz S, Frisch S, Koertke H, Kuhn J, Dreier J, Obermayer-Pietsch B, Wehr E \& Zittermann A. Effect of vitamin D supplementation on testosterone levels in men. Hormone and Metabolic Research 201143 223-225. (https://doi.org/10.1055/s-0030-1269854)

232 Heijboer AC, Oosterwerff M, Schroten NF, Eekhoff EM, Chel VG, de Boer RA, Blankenstein MA \& Lips P. Vitamin D supplementation and testosterone concentrations in male human subjects. Clinical Endocrinology 201583 105-110. (https://doi.org/10.1111/cen.12711)
233 Jorde R, Grimnes G, Hutchinson MS, Kjaergaard M, Kamycheva E \& Svartberg J. Supplementation with vitamin D does not increase serum testosterone levels in healthy males. Hormone and Metabolic Research 201345 675-681. (https://doi.org/10.1055/s-003311345139)

234 Pittas AG, Chung M, Trikalinos T, Mitri J, Brendel M, Patel K, Lichtenstein AH, Lau J \& Balk EM. Systematic review: vitamin D and cardiometabolic outcomes. Annals of Internal Medicine 2010152 307-314. (https://doi.org/10.7326/0003-4819-152-5-201003020-00009)

235 Krul-Poel YH, Ter Wee MM, Lips P \& Simsek S. MANAGEMENT of ENDOCRINE DISEASE: The effect of vitamin D supplementation on glycaemic control in patients with type 2 diabetes mellitus: a systematic review and meta-analysis. European Journal of Endocrinology 2017176 R1-R14. (https://doi.org/10.1530/EJE-16-0391)

236 Lips P, Eekhoff M, van Schoor N, Oosterwerff M, de Jongh R, KrulPoel Y \& Simsek S. Vitamin D and type 2 diabetes. Journal of Steroid Biochemistry and Molecular Biology 2017173 280-285. (https://doi. org/10.1016/j.jsbmb.2016.11.021)

237 Manousaki D, Mokry LE, Ross S, Goltzman D \& Richards JB. Mendelian randomization studies do not support a role for vitamin D in coronary artery disease. Circulation: Cardiovascular Genetics 2016 9 349-356. (https://doi.org/10.1161/CIRCGENETICS.116.001396)

238 Martineau AR, Jolliffe DA, Hooper RL, Greenberg L, Aloia JF, Bergman P, Dubnov-Raz G, Esposito S, Ganmaa D, Ginde AA et al. Vitamin D supplementation to prevent acute respiratory tract infections: systematic review and meta-analysis of individual participant data. BMJ 2017356 i6583. (https://doi.org/10.1136/bmj.i6583)

239 Lappe J, Watson P, Travers-Gustafson D, Recker R, Garland C, Gorham E, Baggerly K \& McDonnell SL. Effect of vitamin D and calcium supplementation on cancer incidence in older women: a randomized clinical trial. JAMA 2017317 1234-1243. (https://doi. org/10.1001/jama.2017.2115)

240 Ong JS, Cuellar-Partida G, Lu Y, Australian Ovarian Cancer S, Fasching PA, Hein A, Burghaus S, Beckmann MW, Lambrechts D, Van Nieuwenhuysen E et al. Association of vitamin D levels and risk of ovarian cancer: a Mendelian randomization study. International Journal of Epidemiology 201645 1619-1630. (https://doi.org/10.1093/ ije/dyw207)

241 Afzal S, Brondum-Jacobsen P, Bojesen SE \& Nordestgaard BG. Genetically low vitamin D concentrations and increased mortality: Mendelian randomisation analysis in three large cohorts. BMJ 2014 349 g6330. (https://doi.org/10.1136/bmj.g6330)

242 Scragg R, Stewart AW, Waayer D, Lawes CMM, Toop L, Sluyter J, Murphy J, Khaw KT \& Camargo CA Jr. Effect of monthly high-dose vitamin D supplementation on cardiovascular disease in the vitamin D assessment study: a randomized clinical trial. JAMA Cardiology 20172 608-616. (https://doi.org/10.1001/jamacardio.2017.0175)

243 Manson JE, Cook NR, Lee IM, Christen W, Bassuk SS, Mora S, Gibson H, Gordon D, Copeland T, D'Agostino D et al. Vitamin D supplements and prevention of cancer and cardiovascular disease. New England Journal of Medicine 2019380 33-44. (https://doi. org/10.1056/NEJMoa1809944)

244 Meyer HE, Holvik K \& Lips P. Should vitamin D supplements be recommended to prevent chronic diseases? BMJ $2015350 \mathrm{~h} 321$. (https://doi.org/10.1136/bmj.h321)

245 Need AG, O'Loughlin PD, Morris HA, Coates PS, Horowitz M \& Nordin BE. Vitamin D metabolites and calcium absorption in severe vitamin D deficiency. Journal of Bone and Mineral Research 200823 1859-1863. (https://doi.org/10.1359/jbmr.080607)

246 Lappe JM, Travers-Gustafson D, Davies KM, Recker RR \& Heaney RP. Vitamin D and calcium supplementation reduces cancer risk: results of a randomized trial. American Journal of Clinical Nutrition $2007 \mathbf{8 5}$ 1586-1591. (https://doi.org/10.1093/ajcn/85.6.1586)

247 Wang TJ, Pencina MJ, Booth SL, Jacques PF, Ingelsson E, Lanier K, Benjamin EJ, D'Agostino RB, Wolf M \& Vasan RS. Vitamin D deficiency and risk of cardiovascular disease. 
Circulation 2008117 503-511. (https://doi.org/10.1161/ CIRCULATIONAHA.107.706127)

248 Grant WB, Cross HS, Garland CF, Gorham ED, Moan J, Peterlik M, Porojnicu AC, Reichrath J \& Zittermann A. Estimated benefit of increased vitamin D status in reducing the economic burden of disease in Western Europe. Progress in Biophysics and Molecular Biology 200999 104-113. (https://doi.org/10.1016/j.pbiomolbio.2009.02.003)

249 Weggemans RM, Kromhout D \& van Weel C. New dietary reference values for vitamin D in the Netherlands. European Journal of Clinical Nutrition 201367 685-685. (https://doi.org/10.1038/ejcn.2013.55)

250 Standing Committee of European Doctors. Vitamin D: Nutritional Policy in Europe. Brussels, 2010. www.cpme.eu

251 Lips P, Wiersinga A, van Ginkel FC, Jongen MJ, Netelenbos JC, Hackeng WH, Delmas PD \& van der Vijgh WJ. The effect of vitamin $\mathrm{D}$ supplementation on vitamin D status and parathyroid function in elderly subjects. Journal of Clinical Endocrinology and Metabolism 1988 67 644-650. (https://doi.org/10.1210/jcem-67-4-644)

252 Mortensen C, Damsgaard CT, Hauger H, Ritz C, Lanham-New SA, Smith TJ, Hennessy Á, Dowling K, Cashman KD, Kiely M et al. Estimation of the dietary requirement for vitamin $\mathrm{D}$ in white children aged 4-8 y: a randomized, controlled, dose-response trial. American Journal of Clinical Nutrition 2016104 1310-1317. (https:// doi.org/10.3945/ajcn.116.136697)

253 Cashman KD, FitzGerald AP, Viljakainen HT, Jakobsen J, Michaelsen KF, Lamberg-Allardt C \& Molgaard C. Estimation of the dietary requirement for vitamin $\mathrm{D}$ in healthy adolescent white girls. American Journal of Clinical Nutrition 201193 549-555. (https://doi. org/10.3945/ajcn.110.006577)

254 Smith TJ, Tripkovic L, Damsgaard CT, Molgaard C, Ritz C, WilsonBarnes SL, Dowling KG, Hennessy Á, Cashman KD, Kiely M et al. Estimation of the dietary requirement for vitamin $\mathrm{D}$ in adolescents aged 14-18 y: a dose-response, double-blind, randomized placebocontrolled trial. American Journal of Clinical Nutrition 2016104 1301-1309. (https://doi.org/10.3945/ajcn.116.138065)

255 Cashman KD, Hill TR, Lucey AJ, Taylor N, Seamans KM, Muldowney S, Fitzgerald AP, Flynn A, Barnes MS, Horigan G et al. Estimation of the dietary requirement for vitamin $\mathrm{D}$ in healthy adults. American Journal of Clinical Nutrition 200888 1535-1542. (https://doi.org/10.3945/ajcn.2008.26594)

256 Cashman KD, Wallace JM, Horigan G, Hill TR, Barnes MS, Lucey AJ, Bonham MP, Taylor N, Duffy EM, Seamans K et al. Estimation of the dietary requirement for vitamin $\mathrm{D}$ in free-living adults $>=64 \mathrm{y}$ of age. American Journal of Clinical Nutrition 200989 1366-1374. (https:// doi.org/10.3945/ajcn.2008.27334)

257 Chakhtoura M, Akl EA, El Ghandour S, Shawwa K, Arabi A, Mahfoud Z, Habib RH, Hoballah H \& El-Hajj Fuleihan G. Impact of vitamin D replacement in adults and elderly in the Middle East and North Africa: a systematic review and meta-analysis of randomized controlled trials. Osteoporosis International 201728 35-46. (https:// doi.org/10.1007/s00198-016-3837-7)

258 Chakhtoura M, El Ghandour S, Shawwa K, Akl EA, Arabi A, Mahfoud Z, Habib R, Hoballah H \& El-Hajj Fuleihan G. Vitamin D replacement in children, adolescents and pregnant women in the Middle East and North Africa: a systematic review and meta-analysis of randomized controlled trials. Metabolism 201770 160-176. (https://doi.org/10.1016/j.metabol.2017.02.009)

259 Cashman KD, Ritz C, Kiely M \& Odin C. Improved dietary guidelines for vitamin D: application of individual participant data (IPD)-level meta-regression analyses. Nutrients 2017 9. (https://doi.org/10.3390/ nu9050469)

260 Manson JE \& Bassuk SS. Vitamin D research and clinical practice: at a crossroads. JAMA 2015313 1311-1312. (https://doi.org/10.1001/ jama.2015.1353)

261 Galior K, Grebe S \& Singh R. Development of vitamin D toxicity from overcorrection of vitamin D deficiency: a review of case reports. Nutrients 201810 E953. (https://doi.org/10.3390/nu10080953)
262 Lee JP, Tansey M, Jetton JG \& Krasowski MD. Vitamin D toxicity: a 16-year retrospective study at an Academic Medical Center. Laboratory Medicine 201849 123-129. (https://doi.org/10.1093/ labmed/lmx077)

263 Taylor PN \& Davies JS. A review of the growing risk of vitamin D toxicity from inappropriate practice. British Journal of Clinical Pharmacology 201884 1121-1127. (https://doi.org/10.1111/bcp.13573)

264 Smith H, Anderson F, Raphael H, Maslin P, Crozier S \& Cooper C. Effect of annual intramuscular vitamin D on fracture risk in elderly men and women, a population-based, randomized, double-blind, placebo-controlled trial. Rheumatology 200746 1852-1857. (https:// doi.org/10.1093/rheumatology/kem240)

265 Schlingmann KP, Kaufmann M, Weber S, Irwin A, Goos C, John U, Misselwitz J, Klaus G, Kuwertz-Broking E, Fehrenbach H et al. Mutations in CYP24A1 and idiopathic infantile hypercalcemia. New England Journal of Medicine 2011365 410-421. (https://doi. org/10.1056/NEJMoa1103864)

266 Jacobs TP, Kaufman M, Jones G, Kumar R, Schlingmann KP, Shapses S \& Bilezikian JP. A lifetime of hypercalcemia and hypercalciuria, finally explained. Journal of Clinical Endocrinology and Metabolism 201499 708-712. (https://doi.org/10.1210/jc.2013-3802)

267 El-Hajj Fuleihan G, Bouillon R, Clarke B, Chakhtoura M, Cooper C, McClung MR \& Singh R. Serum 25-hydroxyvitamin D levels: variability, knowledge gaps and the concept of a desirable range. Journal of Bone and Mineral Research 201530 1119-1133. (https://doi. org/10.1002/jbmr.2536)

268 Bouillon R. Comparative analysis of nutritional guidelines for vitamin D. Nature Reviews Endocrinology 201713 466-479. (https:// doi.org/10.1038/nrendo.2017.31)

269 Pludowski P, Karczmarewicz E, Bayer M, Carter G, Chlebna-Sokol D, Czech-Kowalska J, Debski R, Decsi T, Dobrzanska A, Franek E et al. Practical guidelines for the supplementation of vitamin $\mathrm{D}$ and the treatment of deficits in Central Europe - recommended vitamin D intakes in the general population and groups at risk of vitamin D deficiency. Endokrynologia Polska 201364 319-327. (https://doi. org/10.5603/EP.2013.0012)

270 Haq A, Wimalawansa SJ, Pludowski P \& Anouti FA. Clinical practice guidelines for vitamin D in the United Arab Emirates. Journal of Steroid Biochemistry and Molecular Biology 2018175 4-11. (https://doi. org/10.1016/j.jsbmb.2016.09.021)

271 Al-Daghri NM, Al-Saleh Y, Aljohani N, Sulimani R, Al-Othman AM, Alfawaz H, Fouda M, Al-Amri F, Shahrani A, Alharbi M et al. Vitamin D status correction in Saudi Arabia: an expert's consensus under the auspices of the European Society for Clinical and Economic Aspects of Osteoporosis, osteoarthritis, and musculoskeletal Diseases (ESCEO). Archives of Osteoporosis 201712 1. (https://doi.org/10.1007/ s11657-016-0295-y)

272 LeBlanc ES, Zakher B, Daeges M, Pappas M \& Chou R. Screening for vitamin D deficiency: a systematic review for the U.S. Preventive Services Task Force. Annals of Internal Medicine 2015162 109-122. (https://doi.org/10.7326/M14-1659)

273 Moyer VA \& U.S. Preventive Services Task Force. Vitamin D and calcium supplementation to prevent fractures in adults: U.S. Preventive Services Task Force recommendation statement. Annals of Internal Medicine 2013158 691-696. (https://doi.org/10.7326/00034819-158-9-201305070-00603)

274 Hatun Ş, Ozkan B \& Bereket A. Vitamin D deficiency and prevention: Turkish experience. ACTA Paediatrica 2011100 1195-1199. (https:// doi.org/10.1111/j.1651-2227.2011.02383.x)

275 Binkley N, Gemar D, Engelke J, Gangnon R, Ramamurthy R, Krueger D \& Drezner MK. Evaluation of ergocalciferol or cholecalciferol dosing, $1600 \mathrm{IU}$ daily or $50000 \mathrm{IU}$ monthly in older adults. Journal of Clinical Endocrinology and Metabolism 201196 981-988. (https://doi.org/10.1210/jc.2010-0015)

276 Tripkovic L, Wilson LR, Hart K, Johnsen S, de Lusignan S, Smith CP, Bucca G, Penson S, Chope G, Elliott R et al. Daily supplementation 
with 15 mug vitamin D2 compared with vitamin D3 to increase wintertime 25-hydroxyvitamin D status in healthy South Asian and white European women: a 12-wk randomized, placebo-controlled food-fortification trial. American Journal of Clinical Nutrition 2017106 481-490. (https://doi.org/10.3945/ajcn.116.138693)

277 Shieh A, Chun RF, Ma C, Witzel S, Meyer B, Rafison B, Swinkels L, Huijs T, Pepkowitz S, Holmquist B et al. Effects of high-dose vitamin D2 Versus D3 on total and free 25-hydroxyvitamin D and markers of calcium balance. Journal of Clinical Endocrinology and Metabolism 2016 101 3070-3078. (https://doi.org/10.1210/jc.2016-1871)

278 Ish-Shalom S, Segal E, Salganik T, Raz B, Bromberg IL \& Vieth R. Comparison of daily, weekly, and monthly vitamin D3 in ethanol dosing protocols for two months in elderly hip fracture patients. Journal of Clinical Endocrinology and Metabolism 200893 3430-3435. (https://doi.org/10.1210/jc.2008-0241)

279 Chel V, Wijnhoven HA, Smit JH, Ooms M \& Lips P. Efficacy of different doses and time intervals of oral vitamin D supplementation with or without calcium in elderly nursing home residents. Osteoporosis International 200819 663-671. (https://doi.org/10.1007/ s00198-007-0465-2)

280 Dawson-Hughes B, Harris SS, Lichtenstein AH, Dolnikowski G, Palermo NJ \& Rasmussen H. Dietary fat increases vitamin D-3 absorption. Journal of the Academy of Nutrition and Dietetics 2015115 225-230. (https://doi.org/10.1016/j.jand.2014.09.014)

281 Lerch C \& Meissner T. Interventions for the prevention of nutritional rickets in term born children. Cochrane Database of Systematic Reviews 200717 CD006164. (https://doi.org/10.1002/14651858.CD006164. pub2)

282 Cesur Y, Caksen H, Gundem A, Kirimi E \& Odabas D. Comparison of low and high dose of vitamin $\mathrm{D}$ treatment in nutritional vitamin D deficiency rickets. Journal of Pediatric Endocrinology and Metabolism 200316 1105-1109. (https://doi.org/10.1515/ JPEM.2003.16.8.1105)

283 Ward LM, Gaboury I, Ladhani M \& Zlotkin S. Vitamin D-deficiency rickets among children in Canada. CMAJ 2007177 161-166. (https:// doi.org/10.1503/cmaj.061377)

284 Wheeler BJ, Dickson NP, Houghton LA, Ward LM \& Taylor BJ. Incidence and characteristics of vitamin D deficiency rickets in New Zealand children: a New Zealand Paediatric Surveillance Unit study. Australian and New Zealand Journal of Public Health 201539 380-383. (https://doi.org/10.1111/1753-6405.12390)

285 Munns CF, Shaw N, Kiely M, Specker BL, Thacher TD, Ozono K, Michigami T, Tiosano D, Mughal MZ, Makitie O et al. Global consensus recommendations on prevention and management of nutritional rickets. Journal of Clinical Endocrinology and Metabolism 2016101 394-415. (https://doi.org/10.1210/ jc.2015-2175)

286 De-Regil LM, Palacios C, Ansary A, Kulier R \& Pena-Rosas JP. Vitamin D supplementation for women during pregnancy. Cochrane Database of Systematic Reviews 20122 CD008873.

287 De-Regil LM, Palacios C, Lombardo LK \& Pena-Rosas JP. Vitamin D supplementation for women during pregnancy. Cochrane Database of Systematic Reviews 20161 CD008873.

288 Schoenmakers I, Pettifor JM, Pena-Rosas JP, Lamberg-Allardt C, Shaw N, Jones KS, Lips P, Glorieux FH \& Bouillon R. Prevention and consequences of vitamin D deficiency in pregnant and lactating women and children: a symposium to prioritise vitamin $\mathrm{D}$ on the global agenda. Journal of Steroid Biochemistry and
Molecular Biology 2016164 156-160. (https://doi.org/10.1016/j. jsbmb.2015.11.004)

289 Cashman KD \& Kiely M. EURRECA-estimating vitamin D requirements for deriving dietary reference values. Critical Reviews in Food Science and Nutrition 201353 1097-1109. (https://doi.org/10.10 80/10408398.2012.742862)

290 Cashman KD \& Kiely M. Recommended dietary intakes for vitamin D: where do they come from, what do they achieve and how can we meet them? Journal of Human Nutrition and Dietetics 201427 434-442. (https://doi.org/10.1111/jhn.12226)

291 Flynn A, Hirvonen T, Mensink GB, Ocke MC, Serra-Majem L, Stos K, Szponar L, Tetens I, Turrini A, Fletcher R et al. Intake of selected nutrients from foods, from fortification and from supplements in various European countries. Food and Nutrition Research 200953 1-51. (https://doi.org/10.3402/fnr.v53i0.2038)

292 Cashman KD. Vitamin D: dietary requirements and food fortification as a means of helping achieve adequate vitamin D status. Journal of Steroid Biochemistry and Molecular Biology 2015148 19-26. (https:// doi.org/10.1016/j.jsbmb.2015.01.023)

293 Calvo MS \& Whiting SJ. Survey of current vitamin D food fortification practices in the United States and Canada. Journal of Steroid Biochemistry and Molecular Biology 2013136 211-213. (https:// doi.org/10.1016/j.jsbmb.2012.09.034)

294 Black LJ, Seamans KM, Cashman KD \& Kiely M. An updated systematic review and meta-analysis of the efficacy of vitamin D food fortification. Journal of Nutrition 2012142 1102-1108. (https://doi. org/10.3945/jn.112.158014)

295 Cashman KD \& Kiely M. Tackling inadequate vitamin D intakes within the population: fortification of dairy products with vitamin D may not be enough. Endocrine 201651 38-46. (https://doi. org/10.1007/s12020-015-0711-x)

296 Cashman KD, Kiely M, Seamans KM \& Urbain P. Effect of ultraviolet light-exposed mushrooms on vitamin D status: liquid chromatography-tandem mass spectrometry reanalysis of biobanked sera from a randomized controlled trial and a systematic review plus meta-analysis. Journal of Nutrition 2016146 565-575. (https://doi. org/10.3945/jn.115.223784)

297 Babu US \& Calvo MS. Modern India and the vitamin D dilemma: evidence for the need of a national food fortification program. Molecular Nutrition and Food Research 201054 1134-1147. (https:// doi.org/10.1002/mnfr.200900480)

298 Khaw KT, Stewart AW, Waayer D, Lawes CMM, Toop L, Camargo CA Jr \& Scragg R. Effect of monthly high-dose vitamin D supplementation on falls and non-vertebral fractures: secondary and post-hoc outcomes from the randomised, double-blind, placebo-controlled ViDA trial. Lancet. Diabetes and Endocrinology 20175 438-447. (https://doi.org/10.1016/S2213-8587 (17)30103-1)

299 Bassuk SS, Manson JE, Lee IM, Cook NR, Christen WG, Bubes VY, Gordon DS, Copeland T, Friedenberg G, D'Agostino DM et al. Baseline characteristics of participants in the vitamin D and OmegA-3 TriaL (VITAL). Contemporary Clinical Trials 201647 235-243. (https://doi.org/10.1016/j.cct.2015.12.022)

300 Neale RE, Armstrong BK, Baxter C, Duarte Romero B, Ebeling P, English DR, Kimlin MG, McLeod DS, O'Connell RL, van der Pols JC et al. The D-Health Trial: a randomized trial of vitamin $\mathrm{D}$ for prevention of mortality and cancer. Contemporary Clinical Trials 201648 83-90. (https://doi.org/10.1016/j.cct.2016.04.005)

Received 4 September 2018

Revised version received 11 December 2018

Accepted 31 January 2019 